In cooperation with the Texas State Soil and Water Conservation Board, Coastal Bend Bays and Estuaries Program, and Texas Agrilife Research and Extension Center at Corpus Christi

\title{
Hydrologic Conditions and Water Quality of Rainfall and Storm Runoff for Two Agricultural Areas of the Oso Creek Watershed, Nueces County, Texas, 2005-08
}

Scientific Investigations Report 2010-5136 
Cover: Rainfall on field of grain sorghum, September 2, 2003. 


\section{Hydrologic Conditions and Water Quality of Rainfall and Storm Runoff for Two Agricultural Areas of the 0 so Creek Watershed, Nueces County, Texas, 2005-08}

By Darwin J. Ockerman and Carlos J. Fernandez

In cooperation with the Texas State Soil and Water Conservation Board, Coastal Bend Bays and Estuaries Program, and

Texas Agrilife Research and Extension Center at Corpus Christi

Scientific Investigations Report 2010-5136 


\section{U.S. Department of the Interior \\ KEN SALAZAR, Secretary \\ U.S. Geological Survey \\ Marcia K. McNutt, Director}

U.S. Geological Survey, Reston, Virginia: 2010

This and other USGS information products are available at http://store.usgs.gov/
U.S. Geological Survey
Box 25286, Denver Federal Center
Denver, CO 80225
To learn about the USGS and its information products visit http://www.usgs.gov/
1-888-ASK-USGS

Any use of trade, product, or firm names is for descriptive purposes only and does not imply endorsement by the U.S. Government.

Although this report is in the public domain, permission must be secured from the individual copyright owners to reproduce any copyrighted materials contained within this report.

Suggested citation:

Ockerman, D.J., and Fernandez, C.J., 2010, Hydrologic conditions and water quality of rainfall and storm runoff for two agricultural areas of the Oso Creek watershed, Nueces County, Texas, 2005-08: U.S. Geological Survey Scientific Investigations Report 2010-5136, 63 p. 


\section{Acknowledgments}

Special thanks are extended to Dr. Bobby Eddleman and Carlos Correa from Texas AgriLife Research and Extension Service at Corpus Christi. Dr. Eddleman provided valuable project oversight and technical assistance, including compilation of pesticide and fertilizer application information obtained from producers in the study subwatersheds. Carlos Correa assisted with station and equipment maintenance and sample-collection activities. Thanks also are extended to personnel of the Nueces County Soil and Water Conservation District and the U.S. Department of Agriculture, Natural Resources Conservation Service (NRCS), for assisting in delineating the study subwatersheds and providing contacts with agricultural producers in the subwatersheds. John Freeman, NRCS, also assisted with compilation of information on application rates of fertilizers and pesticides in the study watersheds. 
Blank Page 


\section{Contents}

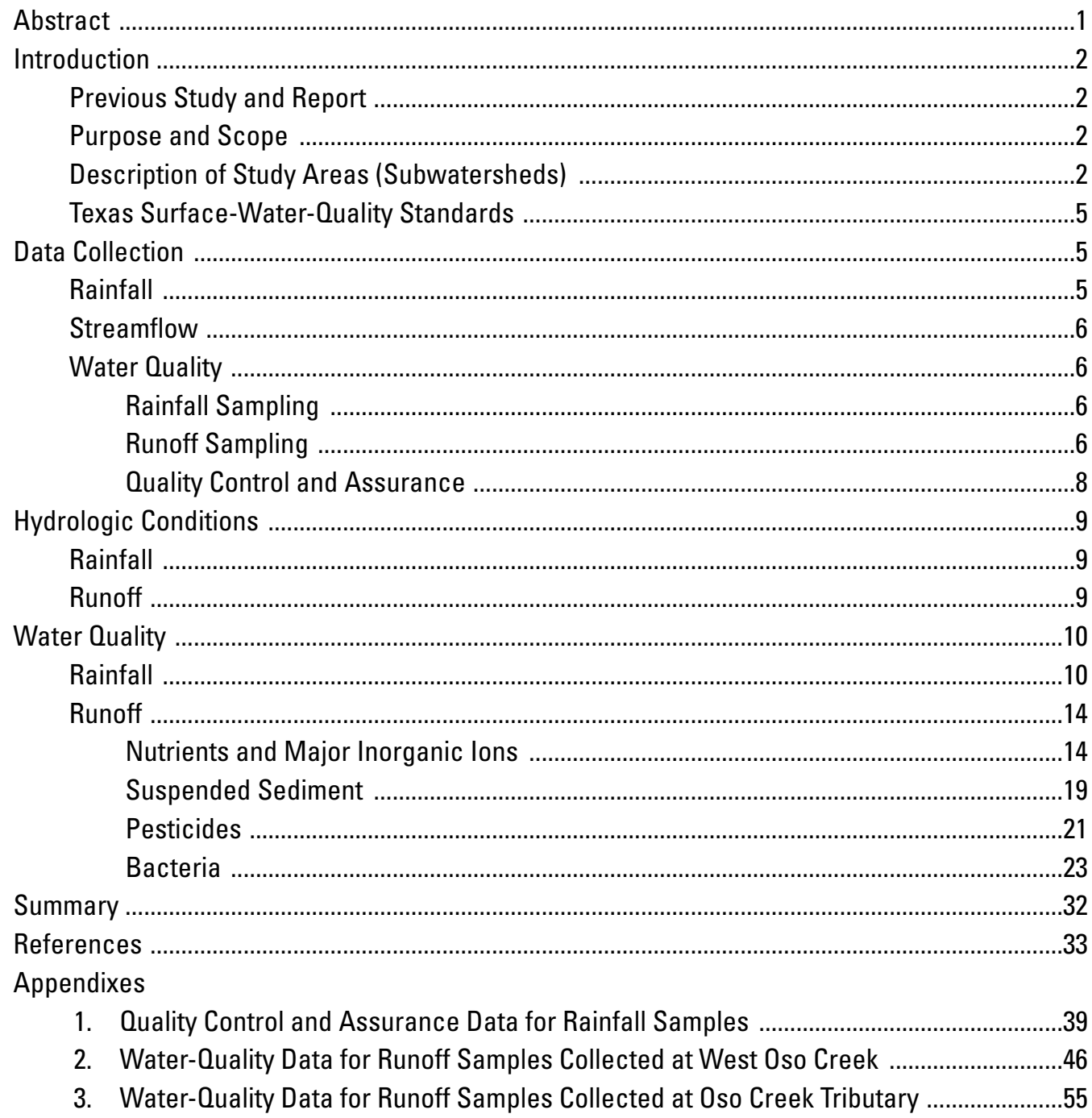

\section{Figures}

1. Map showing Coastal Bend Bays and Estuaries Program (CBBEP) area, South Texas, and Oso Creek watershed area, Nueces County, Texas .......................................

2. Chart showing typical timing of agricultural activities in Nueces County, Texas .............4

3. Photograph showing streamflow-gaging and water-quality monitoring station 08211525, unnamed Oso Creek tributary at Farm Road 2444 near Corpus Christi, Texas, September 19, 2006

4. Hydrograph showing cumulative rainfall, streamflow, and subsample-collection timing at station 08211517, West Oso Creek at Merrett Road near Corpus Christi, Texas, during storm runoff, March 14, 2007

5. Photograph showing suspended-sediment sample collection at station 08211517, West Oso Creek at Merrett Road near Corpus Christi, Texas, June 2, 2006 
6-9. Graphs showing:

6. Mean monthly rainfall for National Weather Service station 412015 , Corpus Christi International Airport, 1960-2008; and monthly area-weighted rainfall for West Oso Creek and Oso Creek tributary subwatersheds (combined), Nueces County, Texas, water years 2006-08

7. Rainfall/runoff response for West Oso Creek and Oso Creek tributary subwatersheds, Nueces County, Texas, March 12-18, 2007

8. Daily deposition of total nitrogen computed from event (daily) rainfall and sample concentrations and estimated by regression with daily rainfall, each relative to daily rainfall, for sampled rainfall events, 0so Creek watershed, Nueces County, Texas, water years 2006-08

9. Relations between suspended-sediment load and streamflow for West Oso Creek (station 08211517) and Oso Creek tributary (station 082115725) subwatersheds, Nueces County, Texas, water years 2006-08

\section{Tables}

1. Monitoring stations providing data used for analysis of hydrologic and waterquality conditions in agricultural areas of the 0 so Creek watershed, Nueces County, Texas

2. Estimated annual (water years 2006-08) rainfall for West Oso Creek and Oso Creek tributary subwatersheds, Nueces County, Texas, and long-term average annual (water years 1960-2008) rainfall measured at National Weather Service station 412015, Corpus Christi International Airport

3. Annual (water years 2006-08) runoff from West Oso Creek and Oso Creek tributary subwatersheds and long-term average annual (water years 1973-2008) runoff from Oso Creek watershed, Nueces County, Texas

4. Rainfall, runoff, and runoff/rainfall coefficients (ratio of runoff volume to rainfall volume) for selected rainfall and runoff events during water years 2006-08, West Oso Creek and Oso Creek tributary subwatersheds, Nueces County, Texas

5. Event (daily) rainfall, Texas AgriLife Research at Corpus Christi weather station (WS1); and event concentrations of selected constituents in rainfall samples, Texas Agrilife Research at Corpus Christi rainfall-quality sampling station (08211511), Nueces County, Texas, water years 2006-08

6. Summary statistics for event rainfall, Texas AgriLife Research at Corpus Christi weather station (WS1); and event concentrations of selected nutrients in rainfall samples, Texas Agrilife Research at Corpus Christi rainfall-quality sampling station (08211511), Nueces County, Texas, water years 2006-08

7. Estimated monthly and annual total nitrogen rainfall deposition on West Oso Creek and Oso Creek tributary subwatersheds, Nueces County, Texas, water years 2006-08

8. Summary statistics for event concentrations of selected nutrients and major inorganic ions in runoff samples, West 0so Creek (station 08211517) and 0so Creek tributary (station 08211525) subwatersheds, Nueces County, Texas, water years 2006-08

9. Event-median concentrations of selected nutrients and major inorganic ions in runoff samples, West Oso Creek (station 08211517) and Oso Creek tributary (station 08211525) subwatersheds, Nueces County, Texas, water years 2006-08; and results of Wilcoxon rank-sum tests to indicate whether event-median concentrations for the two subwatersheds are significantly different 
10. Estimated monthly and annual runoff loads of selected nutrients from West Oso Creek (station 08211517) and Oso Creek tributary (station 08211525) subwatersheds,

Nueces County, Texas, water years 2006-08

11. Estimated annual and average annual runoff yields of selected nutrients from West Oso Creek (station 08211517) and 0so Creek tributary (station 08211525) subwatersheds, Nueces County, Texas, water years 2006-08

12. Fertilizer applications, rainfall deposition, and runoff yields of total nitrogen and total phosphorus for West Oso Creek and Oso Creek tributary subwatersheds, Nueces County, Texas, water years 2006-08

13. Results of analyses for samples of suspended sediment in runoff from West Oso Creek (station 08211517) and Oso Creek tributary (station 08211525) subwatersheds, Nueces County, Texas, water years 2006-08

14. Regression equations relating suspended-sediment load to streamflow for West 0 so Creek (station 08211517) and 0so Creek tributary (station 08211525) subwatersheds, Nueces County, Texas, water years 2006-08

15. Estimated monthly and annual runoff suspended-sediment loads, West Oso Creek (station 08211517) and Oso Creek tributary (station 08211525) subwatersheds, Nueces County, Texas, water years 2006-08

16. Annual and average annual runoff yields of suspended sediment, West 0 so Creek (station 08211517) and Oso Creek tributary (station 08211525) subwatersheds, Nueces County, Texas, water years 2006-08

17. Pesticides used in West 0 so Creek and Oso Creek tributary subwatersheds, Nueces County, Texas, water years 2006-08

18. Summary statistics of concentrations of selected pesticides in runoff samples from West Oso Creek (station 08211517) and Oso Creek tributary (station 08211525) subwatersheds, Nueces County, Texas, water years 2006-08

19. Event-median concentrations of selected pesticides in runoff samples from West 0so Creek (station 08211517) and 0so Creek tributary (station 08211525) subwatersheds, Nueces County, Texas, by season (preharvest or harvest/ postharvest), water years 2006-08, used to estimate runoff loads for unsampled events

20. Estimated monthly and annual runoff loads of selected pesticides from West Oso Creek (station 08211517) and Oso Creek tributary (station 08211525) subwatersheds, Nueces County, Texas, water years 2006-08

21. Estimated annual and average annual application rates and runoff yields of selected pesticides from West 0 so Creek and Oso Creek tributary subwatersheds, Nueces County, Texas, water years 2006-08

22. Bacteria densities in runoff samples from West Oso Creek (station 08211517) and Oso Creek tributary (station 08211525) subwatersheds, Nueces County, Texas, water years 2006-08

23. Summary statistics of bacteria densities in runoff samples from West 0 so Creek (station 08211517) and Oso Creek tributary (station 08211525) subwatersheds, Nueces County, Texas, water years 2006-08; and Texas surface-water-quality standards for bacteria in Oso Bay and Oso Creek, Texas Commission on Environmental Quality segments 2485 and $2485 \mathrm{~A}$, respectively 


\section{Conversion Factors, Datum, and Water-Quality Abbreviations}

\section{Inch/Pound to SI}

\begin{tabular}{|c|c|c|}
\hline Multiply & By & To obtain \\
\hline \multicolumn{3}{|c|}{ Length } \\
\hline inch (in.) & 25.4 & millimeter $(\mathrm{mm})$ \\
\hline foot $(\mathrm{ft})$ & 0.3048 & meter $(\mathrm{m})$ \\
\hline mile (mi) & 1.609 & kilometer $(\mathrm{km})$ \\
\hline \multicolumn{3}{|c|}{ Area } \\
\hline acre & 0.4047 & hectare (ha) \\
\hline square mile $\left(\mathrm{mi}^{2}\right)$ & 2.590 & square kilometer $\left(\mathrm{km}^{2}\right)$ \\
\hline \multicolumn{3}{|c|}{ Volume } \\
\hline acre-foot (acre-ft) & 1,233 & cubic meter $\left(\mathrm{m}^{3}\right)$ \\
\hline \multicolumn{3}{|c|}{ Flow rate } \\
\hline cubic foot per second $\left(\mathrm{ft}^{3} / \mathrm{s}\right)$ & 0.02832 & cubic meter per second $\left(\mathrm{m}^{3} / \mathrm{s}\right)$ \\
\hline million gallons per day (Mgal/d) & 0.04381 & cubic meter per second $\left(\mathrm{m}^{3} / \mathrm{s}\right)$ \\
\hline inch per year (in/yr) & 25.4 & millimeter per year $(\mathrm{mm} / \mathrm{yr})$ \\
\hline \multicolumn{3}{|c|}{ Mass } \\
\hline pound, avoirdupois (lb) & 0.4536 & kilogram $(\mathrm{kg})$ \\
\hline ton, short $(2,000 \mathrm{lb})$ & 0.9072 & megagram (Mg) \\
\hline ton per day (ton/d) & 0.9072 & megagram per day $(\mathrm{Mg} / \mathrm{d})$ \\
\hline \multicolumn{3}{|c|}{ Application rate } \\
\hline pound per acre (lb/acre) & 1.121 & kilogram per hectare $(\mathrm{kg} / \mathrm{ha})$ \\
\hline pound per acre per year $[(\mathrm{lb} / \mathrm{acre}) / \mathrm{yr}]$ & 1.121 & kilogram per hectare per year $[(\mathrm{kg} / \mathrm{ha}) / \mathrm{yr}]$ \\
\hline
\end{tabular}

Temperature in degrees Fahrenheit $\left({ }^{\circ} \mathrm{F}\right)$ may be converted to degrees Celsius $\left({ }^{\circ} \mathrm{C}\right)$ as follows:

$$
{ }^{\circ} \mathrm{C}=\left({ }^{\circ} \mathrm{F}-32\right) / 1.8
$$

\section{Datum}

Horizontal coordinate information is referenced to the North American Datum of 1983 (NAD 83).

\section{Water-Quality Abbreviations}

CFU/100 mL, colony forming units per 100 milliliters

$\mathrm{mg} / \mathrm{L}$, milligrams per liter

$\mu \mathrm{g} / \mathrm{L}$, micrograms per liter

$\mu \mathrm{m}$, micrometers

$\mu \mathrm{S} / \mathrm{cm}$, microsiemens per centimeter at 25 degrees Celsius

$\mathrm{mm}$, millimeters 


\title{
Hydrologic Conditions and Water Quality of Rainfall and Storm Runoff for Two Agricultural Areas of the Oso Creek Watershed, Nueces County, Texas, 2005-08
}

\author{
By Darwin J. Ockerman ${ }^{1}$ and Carlos J. Fernandez ${ }^{2}$
}

\begin{abstract}
The U.S. Geological Survey, in cooperation with the Texas State Soil and Water Conservation Board, Coastal Bend Bays and Estuaries Program, and Texas AgriLife Research and Extension Center at Corpus Christi, studied hydrologic conditions and water quality of rainfall and storm runoff of two primarily agricultural subwatersheds of the Oso Creek watershed in Nueces County, Texas. One area, the upper West Oso Creek subwatershed, is about 5,145 acres. The other area, a subwatershed drained by an unnamed tributary to Oso Creek (hereinafter, Oso Creek tributary), is about 5,287 acres. Rainfall and runoff (streamflow) were continuously monitored at the outlets of the two subwatersheds during the study period October 2005-September 2008. Seventeen rainfall samples were collected and analyzed for nutrients and major inorganic ions. Twenty-four composite runoff water-quality samples (12 at West Oso Creek, 12 at Oso Creek tributary) were collected and analyzed for nutrients, major inorganic ions, and pesticides. Twenty-six discrete suspended-sediment samples (12 West Oso Creek, 14 Oso Creek tributary) and 17 bacteria samples (10 West Oso Creek, 7 Oso Creek tributary) were collected and analyzed. These data were used to estimate, for selected constituents, rainfall deposition to and runoff loads and yields from the two subwatersheds. Quantities of fertilizers and pesticides applied in the two subwatersheds were compared with quantities of nutrients and pesticides in rainfall and runoff.
\end{abstract}

For the study period, total rainfall was greater than average. Most of the runoff from the two subwatersheds occurred in response to a few specific storm periods. The West Oso Creek subwatershed produced more runoff during the study period than the Oso Creek tributary subwatershed, 13.95 inches compared with 9.45 inches. Runoff response was quicker and peak flows were higher in the West Oso Creek subwatershed than in the Oso Creek tributary subwatershed. Total nitrogen runoff yield for the 3-year study period

${ }^{1}$ U.S. Geological Survey, San Antonio, Texas.

${ }^{2}$ Texas AgriLife Research and Extension Center at Corpus Christi, Texas. averaged 2.62 pounds per acre per year from the West Oso Creek subwatershed and 0.839 pound per acre per year from the Oso Creek tributary subwatershed. Total phosphorus yields from the West Oso Creek and Oso Creek tributary subwatersheds for the 3-year period were 0.644 and 0.419 pound per acre per year, respectively. Runoff yields of nitrogen and phosphorus were relatively small compared to inputs of nitrogen in fertilizer and rainfall deposition. Average annual runoff yield of total nitrogen (subwatersheds combined) represents about 2.5 percent of nitrogen applied as fertilizer to cropland in the watershed and nitrogen entering the subwatersheds through rainfall deposition. Average annual runoff yield of total phosphorus (subwatersheds combined) represents about 4.0 percent of the phosphorus in applied fertilizer and rainfall deposition. Suspended-sediment yields from the West Oso Creek subwatershed were more than twice those from the Oso Creek tributary subwatershed. The average suspended-sediment yield from the West Oso Creek subwatershed was 522 pounds per acre per year and from the Oso Creek tributary subwatershed was 139 pounds per acre per year. Twenty-four herbicides and eight insecticides were detected in runoff samples collected at the two subwatershed outlets. At the West Oso Creek site, 19 herbicides and 4 insecticides were detected; at the Oso Creek tributary site, 18 herbicides and 6 insecticides were detected. Fourteen pesticides were detected in only one sample at low concentrations (near the laboratory reporting level). Atrazine and atrazine degradation byproduct 2-chloro-4isopropylamino-6-amino-s-triazine (CIAT) were detected in all samples. Glyphosate and glyphosate byproduct aminomethylphosphonic acid (AMPA) were detected in all samples collected and analyzed during water years 2006-07 but were not included in analysis for samples collected in water year 2008. Of all pesticides detected in runoff, the highest runoff yields were for glyphosate, 0.012 and 0.001 pound per acre per year for the West Oso Creek and Oso Creek tributary subwatersheds, respectively. About 0.9 percent of glyphosate applied to the West Oso Creek subwatershed was detected in runoff and for the Oso Creek tributary subwatershed, about 0.08 percent. At both subwatershed outlet sites, most sample concentrations of fecal coliform, Escherichia coli, and Enterococci were greater than Texas surface-water-quality standards for 
those bacteria established for the receiving waters of Oso Creek and Oso Bay. Because runoff and associated bacteria concentrations represent relatively brief and infrequent conditions, the resulting effect on Oso Creek and Oso Bay is not known.

\section{Introduction}

The Coastal Bend Bays and Estuaries of South Texas is 1 of 28 estuaries or groups of estuaries in the United States that have been designated nationally important and as such are part of the National Estuaries Program of the U.S. Environmental Protection Agency (2008). The Coastal Bend Bays and Estuaries Program (CBBEP) area (fig. 1) encompasses the 12 counties of the Coastal Bend Council of Governments extending from the land cut in the Laguna Madre north along the coast to the Aransas National Wildlife Refuge (Coastal Bend Bays and Estuaries Program, 2008). The bays and estuaries of the CBBEP are affected by nonpoint-source runoff from agricultural land that constitutes about 88 percent of the CBBEP area.

The Oso Creek watershed drains about 234 square miles $\left(\mathrm{mi}^{2}\right)$ to Oso Bay. Agricultural land (pasture and cropland) accounts for about 69 percent of the Oso Creek watershed. Oso Bay, along the southern shore of Corpus Christi Bay, is relatively small (surface area about $7 \mathrm{mi}^{2}$ ) and shallow (average depth about 2.3 feet [ft]) (Quenzer and others, 1998). Ecologically, Oso Bay provides habitat for many plants and animals and is important for water purification and storm protection (Texas Commission on Environmental Quality, 2007).

\section{Previous Study and Report}

The U.S. Geological Survey (USGS), in cooperation with the Texas State Soil and Water Conservation Board (TSSWCB), CBBEP, and Texas AgriLife Research and Extension Center at Corpus Christi (formerly Texas Agricultural Experiment Station-Corpus Christi and hereinafter referred to as Texas AgriLife Research), conducted a study of hydrologic conditions and quality of rainfall and storm runoff of two primarily agricultural subwatersheds of the Oso Creek watershed (fig. 1) during the period October 2005-September 2007. As a result of the study, a USGS Scientific Investigations Report (SIR) (Ockerman, 2008) was published documenting hydrologic conditions and water quality of rainfall and storm runoff for the agricultural study areas during water years 2006-07 (October 2005-September 2007). (A water year is defined as the 12-month period October 1, for any given year, through September 30, of the following year; the water year is designated by the calendar year in which it ends.)

As an extension of the 2005-07 study, the USGS, in cooperation with the TSSWCB, CBBEP, and Texas AgriLife Research continued data collection at the Oso Creek study subwatersheds during October 2007-September 2008 to further characterize hydrologic and water-quality conditions in the Oso Creek watershed.

\section{Purpose and Scope}

The purpose of this report is to characterize hydrologic conditions and the water quality of rainfall and storm runoff for two primarily agricultural subwatersheds in the Oso Creek watershed in Nueces County. The report presents the results of collection and analysis of hydrologic data and water-quality samples of rainfall and runoff during the 3-year data-collection period during October 2005-September 2008. This report supersedes the previous report (Ockerman, 2008) and includes results and analysis of all data collected during the 2005-08 study period. Continuous rainfall and streamflow data were collected at monitoring stations at the outlets of the study subwatersheds. Seventeen rainfall samples were collected and analyzed for nutrients and major inorganic ions. Rainfall nutrient analyses and daily rainfall totals were used to estimate rainfall nutrient deposition to the study subwatersheds. Twenty-four runoff samples were collected by automatic sampling equipment during storm-runoff events. These samples were analyzed for nutrients, major inorganic ions, and pesticides. Twenty-six discrete samples of runoff suspended sediment were collected and analyzed for sediment size and concentration. Seventeen discrete samples of runoff were collected and analyzed for fecal coliform, Escherichia coli (E. coli), and Enterococcus bacteria. These data were used to estimate, for selected constituents, rainfall deposition to and runoff loads and yields from the study subwatersheds. Quantities of fertilizers and pesticides applied in the subwatersheds were compared with quantities of nutrients and pesticides in rainfall and runoff. Estimates of rainfall deposition and runoff constituent loads and yields for 2006-07 in the earlier report of the study watersheds (Ockerman, 2008) were revised in this report on the basis of collection and analysis of additional data.

\section{Description of Study Areas (Subwatersheds)}

Of the two subwatersheds studied (fig. 1), one surrounds the upstream reaches of West Oso Creek and drains about 5,145 acres to Oso Bay. The other surrounds the upstream reaches of an unnamed tributary to Oso Creek (hereinafter, Oso Creek tributary) and drains about 5,287 acres to Oso Bay. The topography of the areas is flat with elevations ranging from about $15 \mathrm{ft}$ above sea level where Oso Creek enters Oso Bay to about $65 \mathrm{ft}$ above sea level in the upland parts of the West Oso Creek subwatershed. Because of negligible relief, the Oso Creek tributary subwatershed might include some noncontributing drainage area. The streams of the study subwatersheds are ephemeral, producing runoff lasting from a few hours to several weeks, depending on rainfall duration and intensity and antecedent soil moisture. 


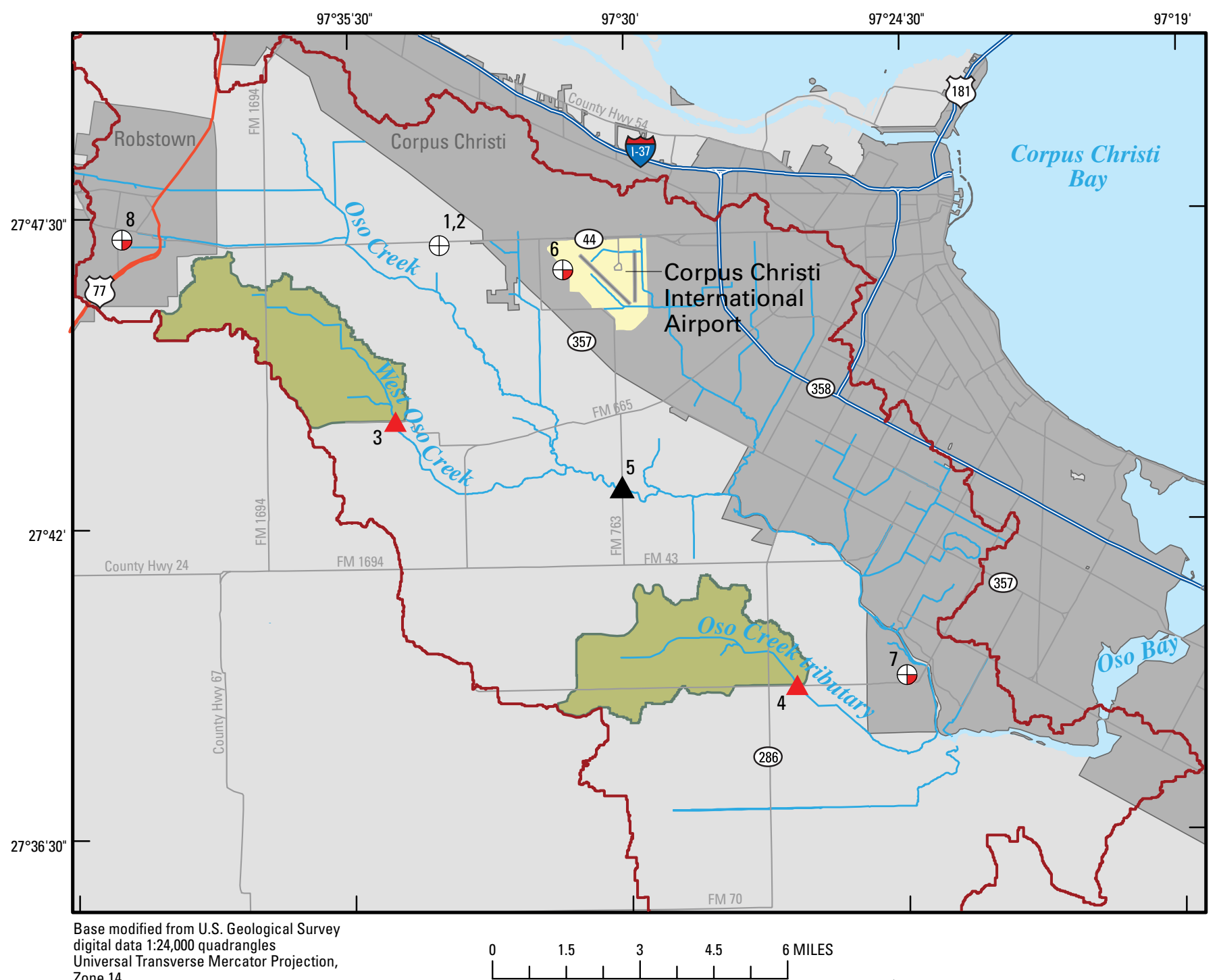

\section{EXPLANATION}

Study area (subwatershed)

\section{_ Boundary of Oso Creek watershed}

Site description—Number referenced in table 1

$1 \oplus$ Texas AgriLife Research weather station and U.S. Geological Survey rainfall sampling station

5 Long-term U.S. Geological Survey streamflowgaging station

${ }^{3}$ U.S. Geological Survey rain gage and streamflowgaging and water-quality sampling station

${ }^{7} \oplus \quad$ National Weather Service rain gage
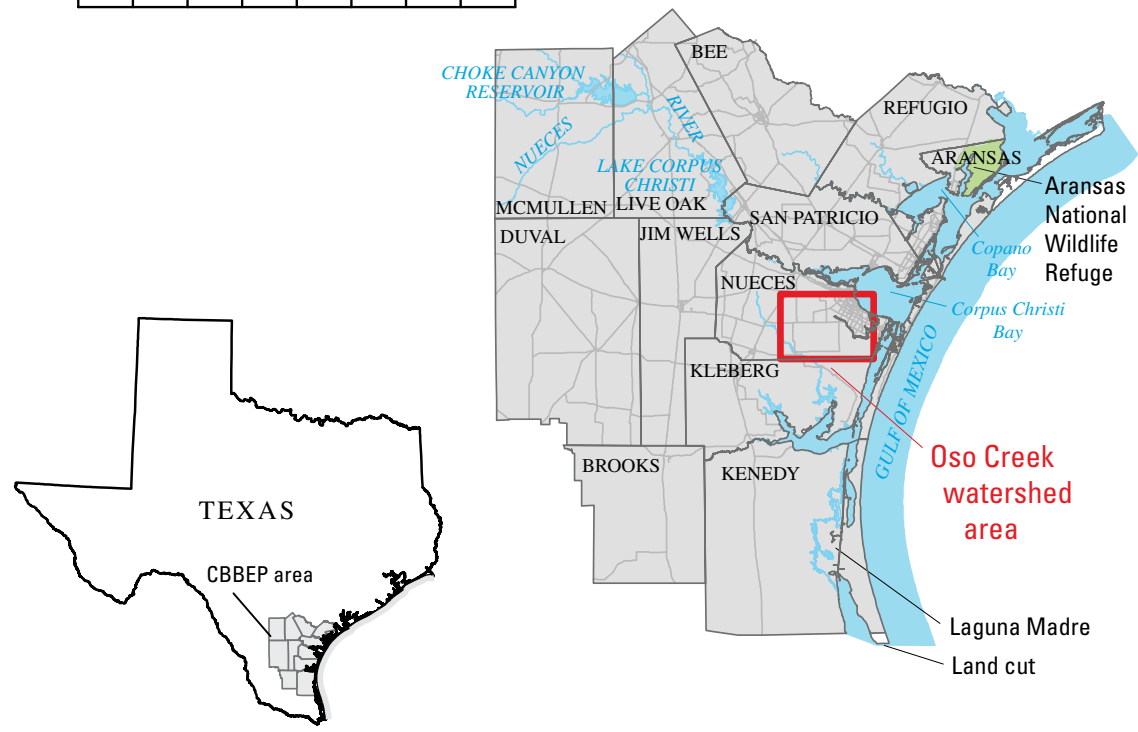

LOCATION MAP

Figure 1. Coastal Bend Bays and Estuaries Program (CBBEP) area, South Texas, and Oso Creek watershed area, Nueces County, Texas. 


\begin{tabular}{|l|l|l|l|l|l|l|l|l|l|l|l|l|}
\hline Activity & Jan. & Feb. & Mar. & Apr. & May & June & July & Aug. & Sept. & Oct. & Nov. & Dec. \\
\hline $\begin{array}{l}\text { Shredding previous crop and } \\
\text { retilling }\end{array}$ & & & & & & & & & & & & \\
\hline $\begin{array}{c}\text { Applying fertilizers and } \\
\text { herbicides }\end{array}$ & & & & & & & & & & & & \\
\hline $\begin{array}{l}\text { Tilling in preparation for } \\
\text { planting }\end{array}$ & & & & & & & & & & & & \\
\hline Planting & & & & & & & & & & & & \\
\hline $\begin{array}{l}\text { Applying pesticides and } \\
\text { cultivating }\end{array}$ & & & & & & & & & & & & \\
\hline Controlling insects (cotton) & & & & & & & & & & & & \\
\hline Harvesting (cotton) & & & & & & & & & & & & \\
\hline
\end{tabular}

Figure 2. Typical timing of agricultural activities in Nueces County, Texas.

The main stem of Oso Creek maintains a continuous flow from wastewater discharges by the cities of Robstown and Corpus Christi. There are no wastewater discharges in the two subwatersheds.

The Oso Creek watershed area is described as having a subtropical, subhumid climate characterized by hot summers and mild, dry winters (Larkin and Bomar, 1983). Maximum annual rainfall tends to occur in spring, early summer, and fall but can occur anytime during the year. The following meteorological statistics are from the National Weather Service (NWS) station at the Corpus Christi International Airport (U.S. Department of Commerce, National Climatic Data Center, 2006). Average annual rainfall (1971-2000) is 32.92 inches (in.); rainfall greater than 0.01 in. occurs, on average, 82 days per year. The average monthly low temperatures range from 46.2 degrees Fahrenheit $\left({ }^{\circ} \mathrm{F}\right)$ in January to $74.5^{\circ} \mathrm{F}$ in August; average monthly high temperatures range from $66.0^{\circ} \mathrm{F}$ in January to $93.4^{\circ} \mathrm{F}$ in August; and mean annual temperature is $71.5^{\circ} \mathrm{F}$.

Besides climate and rainfall, the type and nature of the soils affect the rainfall-runoff process. Victoria Association clays are the dominant soil in the study subwatersheds (U.S. Department of Agriculture, Soil Conservation Service, 1965). During dry periods these soils crack and absorb water rapidly. These natural processes act to reduce runoff. However, once the soils are wet, water infiltrates slowly, which increases the potential for runoff. Thus moisture conditions prior to the onset of substantial rainfall are an important factor affecting runoff.

Agriculture is the predominant land use within each of the study subwatersheds. Land use in each subwatershed is similar, consisting almost entirely (about 98 percent) of cropland. Impervious land (mostly roads) in the study subwatersheds makes up about 2 percent of the total study area (Dr.
Bobby Eddleman, Texas AgriLife Research, written commun., 2007). During 2006-08, the primary crops in the West Oso Creek and Oso Creek tributary subwatersheds were cotton and grain sorghum, accounting for about 92 percent of the total agricultural land. Corn and wheat accounted for about 6 percent of the acreage. The remaining 2 percent was fallow or pasture (Dr. Bobby Eddleman, Texas AgriLife Research, written commun., 2007; Dr. Carlos Fernandez, Texas AgriLife Research, written commun., 2009).

Beginning in late July through early September, crops are harvested and remaining crop residue is shredded and stubble is plowed. Postcrop emergents are controlled with herbicides (in the conservation tillage systems); any residual vegetation is killed as well. The process of tilling and spraying the fields after harvest helps prepare the ground to absorb fall and winter rains (fig. 2) (Dr. Bobby Eddleman, Texas AgriLife Research, written commun., 2007). The soil is retilled or resprayed during September and October to destroy winter weeds and to prepare the seedbed for the succeeding crop. Preplant fertilizers and broadcast preemergent herbicides usually are applied during the low-rainfall months of November and December. From January to mid-February, additional tilling might be done to prepare for planting. Planting begins in early to late March, depending on the available soil moisture, soil temperature, and type of crop. After crops have emerged from the soil, production practices throughout the season consist of pesticide application and row cultivation. From mid- to late April through early July, few field operations are required for grain sorghum. In contrast, this period involves ongoing insect control for cotton. Grain sorghum usually is harvested in early to mid-July. Cotton harvest usually begins with application of harvest aids (defoliants) around mid-July and ends around mid-August to early September. 
Table 1. Monitoring stations providing data used for analysis of hydrologic and water-quality conditions in agricultural areas of the Oso Creek watershed, Nueces County, Texas.

[Texas AgriLife Research, Texas AgriLife Research and Extension Center at Corpus Christi; USGS, U.S. Geological Survey; NWS, National Weather Service; --, unknown]

\begin{tabular}{|c|c|c|c|c|c|}
\hline $\begin{array}{c}\text { Site } \\
\text { number } \\
\text { (fig. 1) }\end{array}$ & Station name, number & $\begin{array}{c}\text { Latitude } \\
\text { (degrees } \\
\text { minutes } \\
\text { seconds) } \\
\end{array}$ & $\begin{array}{l}\text { Longitude } \\
\text { (degrees } \\
\text { minutes } \\
\text { seconds) } \\
\end{array}$ & $\begin{array}{l}\text { Type of } \\
\text { data }\end{array}$ & $\begin{array}{l}\text { Period of } \\
\text { record used }\end{array}$ \\
\hline 1 & $\begin{array}{l}\text { Weather station WS1, Texas AgriLife Research at Corpus } \\
\text { Christi, Tex. }\end{array}$ & $27^{\circ} 46^{\prime} 57^{\prime \prime}$ & $97^{\circ} 33^{\prime} 43^{\prime \prime}$ & $\begin{array}{l}\text { Hourly and daily } \\
\text { rainfall }\end{array}$ & $\begin{array}{l}\text { Oct. } 2005- \\
\text { Sept. } 2008\end{array}$ \\
\hline 2 & $\begin{array}{l}\text { USGS station 08211511, Texas AgriLife Research at Corpus } \\
\text { Christi, Tex. }\end{array}$ & $27^{\circ} 46^{\prime} 57^{\prime \prime}$ & $97^{\circ} 33^{\prime} 43^{\prime \prime}$ & Rainfall quality & $\begin{array}{l}\text { Oct. } 2005- \\
\text { Sept. } 2008\end{array}$ \\
\hline 3 & $\begin{array}{l}\text { USGS station 08211517, West Oso Creek at Merrett Road } \\
\text { near Corpus Christi, Tex. }\end{array}$ & $27^{\circ} 43^{\prime} 50^{\prime \prime}$ & $97^{\circ} 34^{\prime} 37^{\prime \prime}$ & $\begin{array}{l}\text { Rainfall, streamflow, } \\
\text { water quality }\end{array}$ & $\begin{array}{l}\text { Oct. 2005- } \\
\text { Sept. } 2008\end{array}$ \\
\hline 4 & $\begin{array}{l}\text { USGS station } 08211525 \text {, Unnamed Oso Creek tributary at } \\
\text { Farm Road } 2444 \text { near Corpus Christi, Tex. }\end{array}$ & $27^{\circ} 39^{\prime} 07^{\prime \prime}$ & $97^{\circ} 26^{\prime} 40^{\prime \prime}$ & $\begin{array}{l}\text { Rainfall, streamflow, } \\
\text { water quality }\end{array}$ & $\begin{array}{l}\text { Oct. } 2005- \\
\text { Sept. } 2008\end{array}$ \\
\hline 5 & USGS station 08211520, Oso Creek at Corpus Christi, Tex. & $27^{\circ} 42^{\prime} 40^{\prime \prime}$ & $97^{\circ} 30^{\prime} 06^{\prime \prime}$ & Streamflow & $\begin{array}{l}\text { Oct. } 1972- \\
\quad \text { Sept. } 2008\end{array}$ \\
\hline 6 & NWS station 412015, Corpus Christi International Airport & $27^{\circ} 46^{\prime}--"$ & $97^{\circ} 31^{\prime--"}$ & $\begin{array}{l}\text { Hourly and daily } \\
\text { rainfall }\end{array}$ & $\begin{array}{l}\text { January } 1972- \\
\text { Sept. } 2008\end{array}$ \\
\hline 7 & NWS station 412013, Corpus Christi Botanical Gardens & $27^{\circ} 39^{\prime}--"$ & $97^{\circ} 24^{\prime}--"$ & Daily rainfall & $\begin{array}{l}\text { Oct. 2005- } \\
\text { Sept. } 2008\end{array}$ \\
\hline 8 & NWS station 417677, Robstown, Tex. & $27^{\circ} 47^{\prime--"}$ & $97^{\circ} 40^{\prime}--"$ & Daily rainfall & $\begin{array}{l}\text { Oct. } 2005- \\
\text { Sept. } 2008\end{array}$ \\
\hline
\end{tabular}

\section{Texas Surface-Water-Quality Standards}

The Texas Commission on Environmental Quality (TCEQ) has designated Texas surface-water-quality standards (TSWQS) and appropriate uses (such as aquatic life, contact or noncontact recreation, or drinking water) for specific stream, estuary, and bay segments (Texas Commission on Environmental Quality, 2006). TSWQS have not been established for either specific streams or subwatersheds in this study (West Oso Creek and Oso Creek tributary). However, the two subwatersheds drain to Oso Creek and Oso Bay, which are water bodies with TSWQS. The TSWQS are defined by a combination of designated uses and criteria necessary to maintain the designated uses. The designated uses for Oso Bay are contact recreation and aquatic life. Oso Creek (TCEQ segment $2485 \mathrm{~A}$ ) is considered an unclassified water body associated with a classified segment, Oso Bay (TCEQ segment 2485). Oso Creek, segment 2485A, includes all of Oso Creek to its confluence with Oso Bay. Oso Creek and Oso Bay are on the "2008 Texas Water Quality Inventory and 303d List" (Texas Commission on Environmental Quality, 2008) for elevated bacteria counts. Oso Bay also is listed for depressed dissolved oxygen concentration.

\section{Data Collection}

Monitoring stations providing data for this study are listed in table 1 and include an hourly weather station with rain gage operated by Texas AgriLife Research (site 1); a USGS rainfall-quality sampling station (site 2); two USGS rainfall, streamflow, and water-quality sampling stations located at the outlets of the study subwatersheds (sites 3,4); a long-term USGS streamflow-gaging station on the main stem of Oso Creek (site 5); and three NWS rain gages (sites 6, 7, 8).

\section{Rainfall}

Rainfall amounts in the Oso Creek watershed area were obtained from six monitoring stations (fig. 1; table 1). Hourly and daily rainfall data were recorded at the Texas AgriLife Research weather station (site 1). Two tipping-bucket rain gages were installed, one at each monitoring station at the outlet of each study subwatershed (sites 3,4 ). These stations recorded 15-minute rainfall totals. Also, daily rainfall data were obtained from three NWS rain gages (sites 6, 7, 8). Daily rainfall in the West Oso Creek study subwatershed was estimated by using a Thiessen-weighted average (Wanielista, 1990) of rainfall measured at sites 1,3 , and 8. Daily rainfall in the Oso Creek tributary subwatershed was estimated by using rainfall primarily from site 4 . The NWS Corpus Christi Botanical Gardens station (site 7) was used for estimating daily rainfall on the Oso Creek tributary subwatershed for days when data were not available from site 4 , including all of the period October 2007-September 2008. Rainfall data from the NWS Corpus Christi International Airport station (site 6) were used to represent long-term rainfall conditions in both subwatersheds. 


\section{Streamflow}

Water-surface elevation (stage) was continuously monitored (at 15-minute intervals) at the study subwatershed stations (sites 3, 4, table 1) by up-looking acoustic transducers mounted on the streambeds (SonTek, 2010). At each station, relations between stage and runoff (streamflow) were developed from streamflow measurements made during various flow conditions during runoff events (Buchanan and Somers, 1969). From these relations, continuous runoff was computed for each study subwatershed (Kennedy, 1984).

\section{Water Quality}

Water-quality samples were collected for two sources, rainfall and runoff. Rainfall-quality samples were collected to measure nutrient concentrations and compute nutrient deposition to the study subwatersheds. Runoff-quality samples were collected to characterize runoff quality and to estimate constituent loads and yields of selected nutrients, suspended sediment, and pesticides transported from the study subwatersheds. Also, runoff-quality samples were collected during runoff events and analyzed for fecal coliform, E. coli, and Enterococci bacteria.

\section{Rainfall Sampling}

Rainfall samples for nutrients and major inorganic ions were collected at the USGS rainfall-quality sampling station (site 2 , table 1 ) by an automatic rainfall sampler. The automatic rainfall sampler is equipped with a polyethylene bucket that is covered to prevent contamination of the bucket and sample when rainfall is not occurring. A moisture sensor activates a mechanism to uncover the sample-collection bucket when rainfall begins and to cover the sample when rainfall ends. Rainfall samples were collected as a single composite sample for rainfall events. Results of the analyses of the composite samples represent the average constituent concentrations during rainfall events. As soon as possible after rainfall, samples were retrieved from the rainfall sample collector and immediately placed on ice. With the use of a Teflon churn, the composite rainfall sample was then split into various sample containers for overnight shipment to the USGS National Water Quality Laboratory (NWQL), Lakewood, Colo., for analysis. Part of the sample was bottled as unfiltered samples, representing whole-water samples. Analyses of unfiltered samples provided concentrations of total phosphorus and total Kjeldahl nitrogen (ammonia nitrogen plus organic nitrogen). Some samples were filtered through 0.45-micrometer $(\mu \mathrm{m})$ pore-diameter filters. Analyses of filtered samples provided concentrations of dissolved ammonia as $\mathrm{N}$ (nitrogen), nitrite plus nitrate nitrogen, phosphorus, and orthophosphate phosphorus. Major inorganic ion samples also were filtered by using a $0.45-\mu \mathrm{m}$ pore-diameter filters. Analytical methods are described in Fishman (1993), Fishman and Friedman (1989),
Patton and Truitt (2000), and U.S. Environmental Protection Agency (1993).

\section{Runoff Sampling}

Automatic water samplers at the runoff-monitoring stations (sites 3, 4, table 1) collected runoff samples for nutrients, major inorganic ions, and pesticides during storm events. When runoff was detected by the streamflow-gaging instrumentation (fig. 3), automatic water-quality samplers were activated to collect samples. Discrete aliquots (water-quality subsamples) were collected hourly during a period of runoff. Near or at the end of the runoff event, sampling was completed and the aliquots from each site were combined into a single streamflow-weighted composite sample (separate composite samples from each station). For example, an aliquot collected when streamflow measured 10 cubic feet per second $\left(\mathrm{ft}^{3} / \mathrm{s}\right)$ would have twice the volume in the composite sample as an aliquot that was collected when streamflow measured $5 \mathrm{ft}^{3} / \mathrm{s}$. In this way, analysis of the composite sample represents the event-mean concentration (EMC) during runoff (Huber, 1993, p. 14.1). Figure 4 shows a rainfall-streamflow hydrograph at West Oso Creek for March 14, 2007, including the subsamplecollection timing during the event. As runoff samples were retrieved from the autosampler they were immediately chilled to preserve their composition (Komor and Hansen, 2003). When sample collection was complete, portions of each individual aliquot, based on flow at the time of aliquot collection, were combined in a Teflon churn. Samples were then processed from the churn and bottled as either unfiltered or filtered samples (Wilde and others, 2004) and submitted for laboratory analysis to the NWQL. Similar to rainfall samples, nutrient samples were processed from the churn and bottled as unfiltered and filtered $(0.45-\mu \mathrm{m}$ pore-diameter filters) samples for laboratory analysis. Major inorganic ion samples were filtered through $0.45-\mu \mathrm{m}$ pore-diameter filters, and pesticide

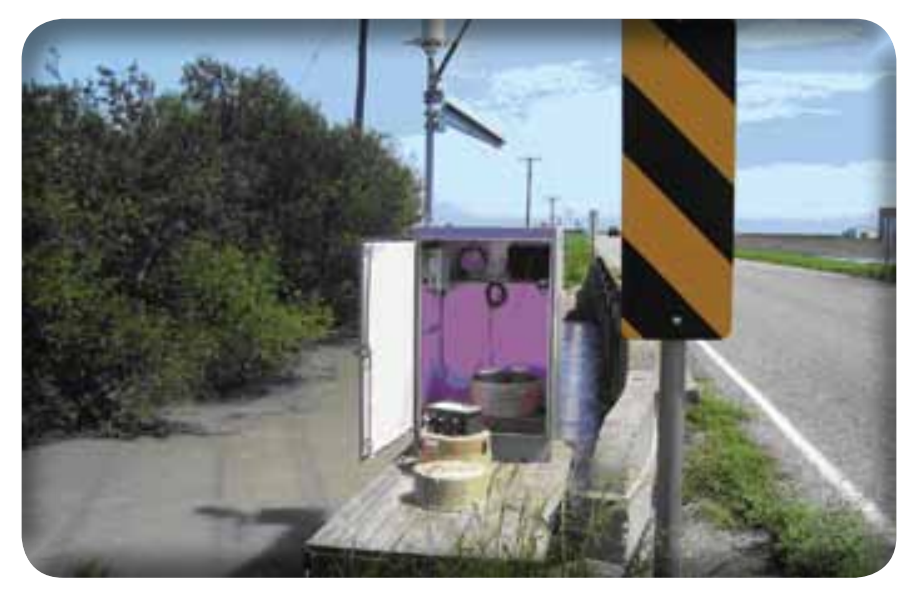

Figure 3. Streamflow-gaging and water-quality monitoring station 08211525, unnamed Oso Creek tributary at Farm Road 2444 near Corpus Christi, Texas, September 19, 2006. 


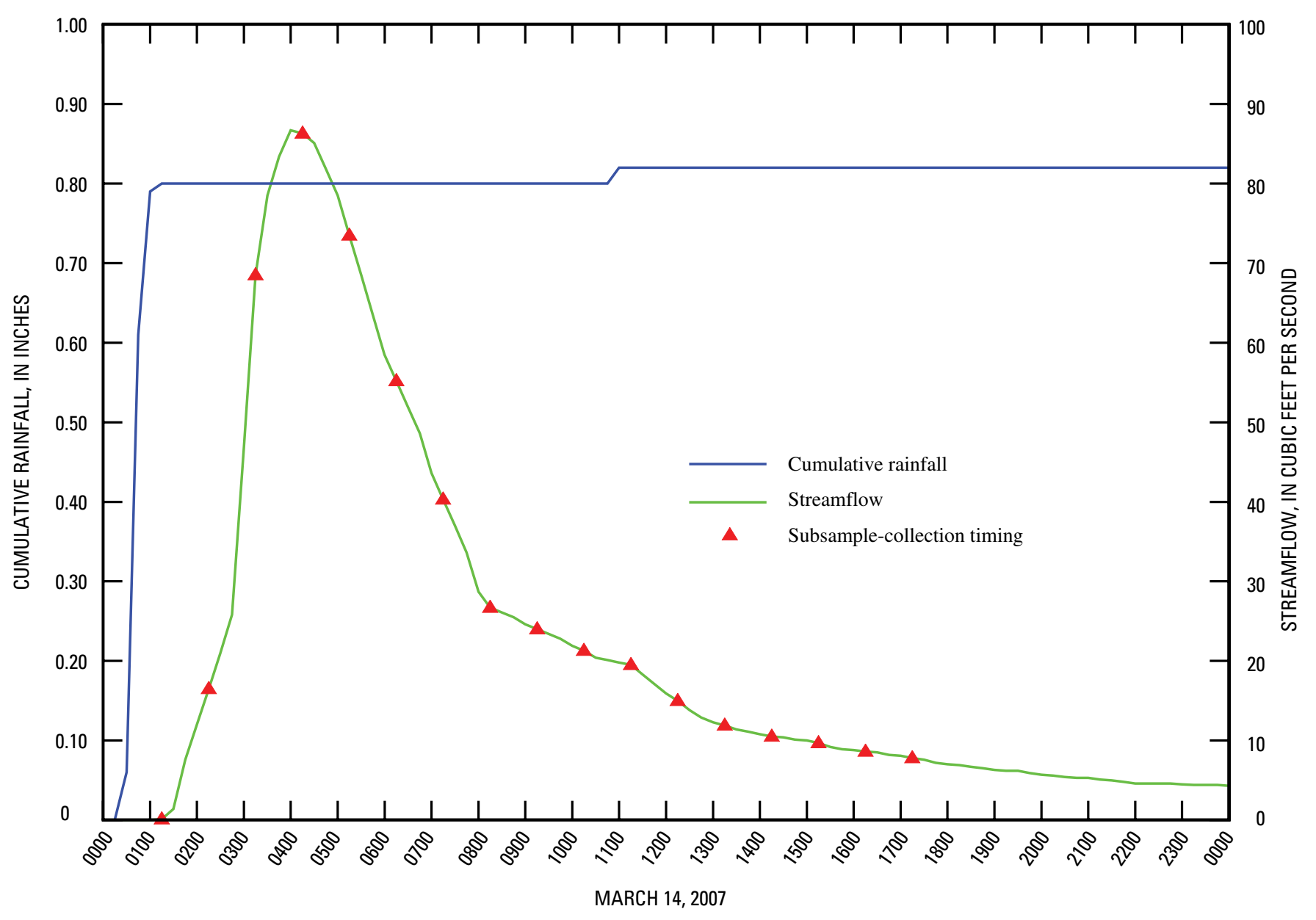

Figure 4. Hydrograph showing cumulative rainfall, streamflow, and subsample-collection timing at station 08211517 , West 0 so Creek at Merrett Road near Corpus Christi, Texas, during storm runoff, March 14, 2007.

samples were filtered through $0.7-\mu \mathrm{m}$ pore-diameter filters. Analytical methods are described in Fishman (1993), Fishman and Friedman (1989), Furlong and others (2001), Lindley and others (1996), Madsen and others (2003), Patton and Truitt (2000), Sandstrom and others (2001), U.S. Environmental Protection Agency (1993), and Zaugg and others (1995).

Suspended-sediment samples also were collected during storm-runoff events. Suspended-sediment samples were collected as discrete samples during various streamflow conditions. Samples were collected by the flow-weighted, depthintegrating, equal-width increment (EWI) method (sampler is raised and lowered through the water column at equal intervals across the stream) (U.S. Geological Survey, 2006) with isokinetic samplers US DH-48 and US DH-59 (Federal Interagency Sedimentation Project, 2010). An isokinetic sampler collects a water-sediment sample from the stream at a rate such that the velocity of the intake nozzle is equal to the incident stream velocity at the nozzle entrance. The water-sediment sample collected is thus representative of the suspended-sediment load throughout the channel cross section and is appropriate for use in estimating sediment load carried by the stream (Davis, 2005). Suspended-sediment samples were collected by wading (fig. 5) or with bridge-suspended equipment during relatively large streamflows. During collection of a suspended-sediment sample at a particular station, samples collected at each vertical section in the stream were combined in a Teflon churn and processed as a composite sample for analysis. The composite sample represents the flow-weighted average suspended-sediment concentration during the period of sample collection. Suspended-sediment samples were analyzed by the USGS sediment laboratory in Iowa City, Iowa. Samples were analyzed for suspendedsediment concentration and sand-break analysis (Guy, 1969). Sand-break analysis gives the percentage of sediment by weight that is finer than 0.062 millimeter $(\mathrm{mm})$. Particle sizes less than $0.062 \mathrm{~mm}$ are defined as silt and clay. Particles greater than $0.062 \mathrm{~mm}$ are defined as sand.

Discrete bacteria samples were collected during several events at each of the sampling stations. Samples were collected by Texas AgriLife Research personnel and analyzed by the Texas A\&M University Environmental Microbiology Laboratory in Corpus Christi. Bacteria samples were collected 


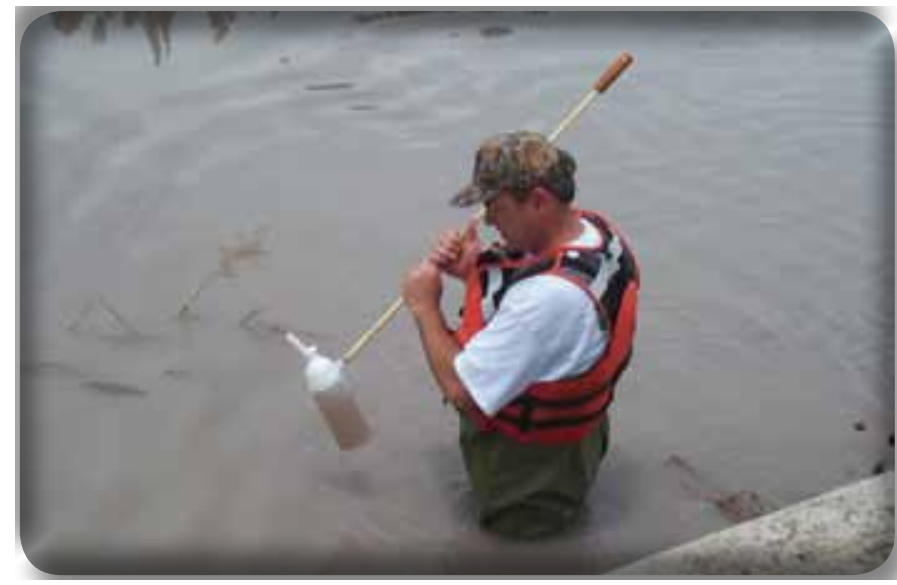

Figure 5. Suspended-sediment sample collection at station 08211517, West 0so Creek at Merrett Road near Corpus Christi, Texas, June 2, 2006.

as grab samples from the centroid of flow and analyzed by membrane filtration for fecal coliform (American Public Health Association, 1998), E. coli (American Public Health Association, 1998), and Enterococci (U.S. Environmental Protection Agency, 2000). The objective for bacteria sampling was a single sample collected as soon as possible after runoff began. Accordingly, samples were collected within several hours of the beginning of runoff and do not necessarily represent average concentrations during the entire runoff event.

\section{Quality Control and Assurance}

Quality control (QC) samples, designed to ensure the integrity of water-quality data analyzed in this report, represented more than 10 percent of field samples collected. QC samples consisted of five field blanks that were collected and analyzed to evaluate any contamination, as well as bias and variability of data, which might have resulted from sample collection, processing, transportation, and lab analysis. These samples were collected by passing USGS-certified, highly purified water through the same equipment used to collect and process routine water-quality samples. These blank samples were then collected, processed, and analyzed in the same way as routine environmental samples.

Two field blank samples were collected at the Texas AgriLife Research rainfall-quality site (station 08211511) and analyzed for nutrients and inorganic ions. Two field blank samples were collected at the West Oso Creek subwatershed outlet site (station 08211517). The first of these samples, collected in November 2006, was analyzed for pesticides. The second sample, collected in October 2007, was analyzed for nutrients and inorganic ions. One blank sample was collected at the Oso Creek tributary subwatershed outlet site (station 08211525) in March 2006 and analyzed for nutrients and inorganic ions. Field blank samples were not collected or analyzed for sediment or bacteria samples. QC and assurance methods for sediment and bacteria focused on laboratory analytical procedures.

Most compounds were not detected in the blank samples, but if detected the reported concentrations were less than or near the laboratory reporting level for the compounds (appendix 1). The concentration of the laboratory reporting level is reported with a "less than" $(<)$ remark code (appendix 1) for samples in which the analyte was not detected. Concentrations reported by the NWQL for pesticides are flagged as "estimated" (indicated by an "E" where reported) when they are qualitatively identified as present, but the reported concentrations have a greater uncertainty than usual (Childress and others, 1999). Cases that result in an "estimated" flag include concentrations that are less than the laboratory reporting level but still detectable in the analyst's judgment. Estimated flags also are associated with any detection of the atrazine degradation compounds 2-chloro-4-isopropylamino-6-amino-striazine (CIAT) and 2-chloro-6-ethylamino-4-amino-s-triazine (CEAT). Estimated flags are automatically applied to any CIAT and CEAT detections because of poor performance results during laboratory quality-assurance testing (U.S. Geological Survey, 2010). Estimated concentrations were included in computations of event loads and yields and for statistical analyses. Laboratory reporting levels for some compounds changed during the study. The NWQL updates laboratory reporting levels yearly on the basis of results of internal QC sample analyses.

Reported concentrations for certain nutrient constituents are not analyzed directly but are computed from other constituent concentrations. Computed constituents included dissolved (filtered) and total (unfiltered) nitrogen, dissolved and total organic nitrogen, and dissolved nitrate nitrogen. Laboratory analyses are performed explicitly for ammonia nitrogen, nitrite nitrogen, dissolved nitrite plus nitrate nitrogen, ammonia plus dissolved organic nitrogen, and ammonia plus total organic nitrogen. Dissolved nitrogen is computed as the sum of nitrite plus nitrate nitrogen and ammonia plus dissolved organic nitrogen (filtered); total nitrogen is computed as the sum of nitrite plus nitrate nitrogen and ammonia plus total organic nitrogen (unfiltered). Dissolved organic nitrogen is computed as the difference between ammonia plus dissolved organic nitrogen (filtered) and ammonia nitrogen alone; total organic nitrogen is computed as the difference between ammonia plus total organic nitrogen (unfiltered) and ammonia nitrogen alone. Nitrate nitrogen is computed as the difference between nitrite plus nitrate nitrogen and nitrite nitrogen alone.

QC and assurance procedures applied by the USGS NWQL and sediment laboratories include the determination and tracking of long-term method detection level, internal and external audits, and blind-blank and blind-spike programs that use standard reference materials. Laboratory quality assurance data and methods are documented in U.S. Geological Survey (2007).

Quality assurance procedures applied by the Texas A\&M microbiology laboratory for bacteria include field split samples, laboratory duplicates, and method blanks (Texas 
Commission on Environmental Quality, 2003). Analytical results of laboratory duplicates and field split replicates are included with primary bacteria sample results.

Water-quality sample data were reviewed by a USGS data manager before data were entered into the USGS National Water Information System (NWIS) (U.S. Geological Survey, 2008). The emphasis of the review was to verify the accuracy and completeness of the laboratory data, to determine whether laboratory QC and assurance data were within acceptable limits, and to determine whether samples were handled appropriately in the field and the laboratory.

\section{Hydrologic Conditions}

The 3-water-year study period represents three crop cycles in the study subwatersheds. Water year 2006 was very dry, especially during the planting and preharvest period of February through May. In fact, some producers did not plant or abandoned crops because of lack of rainfall. Water years 2007 and 2008 were relatively typical years in terms of agricultural practices (Dr. Carlos Fernandez, Texas AgriLife Research, written commun., 2008).

\section{Rainfall}

Long-term (1960-2008) rainfall from the NWS Corpus Christi International Airport station (site 6, table 1) was compared with rainfall in the subwatersheds during water years 2006-08 (October 2005-September 2008) (table 2). Average annual rainfall in the Corpus Christi area during 1960-2008 was 31.66 in. Area-weighted, average annual rainfall on the two study subwatersheds during water years 2006-08 was 33.26 in. Although rainfall during 2006 was less than normal ( 29.97 in.), the period of June-August included several major runoff events. Rainfall in water year 2007 was above average (45.03 in.), with especially heavy rainfall during July 2007, about 15 in. Rainfall in water year 2008 was substantially less than average in the West Oso Creek subwatershed (19.61 in.) but only slightly less than average in the Oso Creek tributary subwatershed (29.10 in.).

Mean (1960-2008) monthly rainfall for the NWS Corpus Christi International Airport station and monthly area-weighted rainfall for the West Oso Creek and Oso Creek tributary subwatersheds (combined) for October 2005September 2006, October 2006-September 2007, and October 2007-September 2008 are shown in figure 6. Although study area rainfall was greater than average during the 3-year study period, monthly rainfall was less than average during 23 of the 36 months.

\section{Runoff}

The USGS, in cooperation with the Texas Water Development Board, has operated streamflow-gaging station 08211520 Oso Creek at Corpus Christi, Tex., since
1972 (site 5, fig. 1; table 1). Data from this station were used to estimate long-term annual runoff volumes for comparison with study subwatershed runoff volumes. Land use in the $90.3-\mathrm{mi}^{2}$ watershed upstream from the gaging station is largely cropland, similar to that in the study subwatersheds. However, a substantial amount of impervious cover, associated with the town of Robstown, is located upstream from the station. Average streamflow during water years 1973-2008 was $30.6 \mathrm{ft}^{3} / \mathrm{s}$. Excluding an estimated wastewater treatment discharge of about 3 million gallons per day (Mgal/d) from Robstown, long-term average annual runoff at the Oso Creek at Corpus Christi station was 3.90 in. (table 3). During water years 2006-08, average annual runoff at the Oso Creek at Corpus Christi station was greater than average, 5.82 in. So, it is likely that 2006-08 represents a period of greater than average runoff for the study area subwatersheds.

Runoff during water years $2006-08$ corresponded to rainfall patterns, with rainfall and runoff events interspersed between considerable periods of no runoff. Selected rainfall and runoff events (typically rainfall greater than 1.0 in. or runoff greater than 0.001 in., or both) are listed in table 4, including dates, rainfall totals, runoff volumes, and runoff coefficients (ratio of runoff volume, in inches, to rainfall volume, in inches). Most of the minor rainfall and runoff events, for which study subwatersheds had less than $0.01 \mathrm{in}$. of runoff, are not listed separately but are included in the totals for October 2005-September 2008 listed in table 4. Table 4 also indicates whether runoff water-quality samples were collected during the event. Appendix 2 (West Oso Creek) and appendix 3 (Oso Creek tributary) list waterquality data for all sampled runoff events during water years 2006-08.

Runoff is highly dependent on antecedent conditions. Rainfall of 2 to 3 in. during May 25-29, 2007, resulted in no runoff or only minor runoff at the subwatershed sites. Less rainfall during January 24-February 3, 2007, produced substantially more runoff because of antecedent wet conditions from substantial rainfall in early January.

Most of the runoff from the study subwatersheds occurred in response to a few specific storm periods (events). More than 60 percent of the runoff from each subwatershed occurred during two wet periods: September 18-October 1, 2006, and July 2-August 8, 2007 (table 4). During both periods, multiple rainfall events and prolonged wet-soil conditions contributed to substantial runoff.

The West Oso Creek subwatershed produced more runoff during the study period than the Oso Creek tributary subwatershed, 13.95 in. compared with 9.45 in. (table 4). Runoff response was quicker and peak flows were larger in the West Oso Creek subwatershed than in the Oso Creek tributary subwatershed. Differences in hydrologic response between the subwatersheds might be explained by slightly greater land slopes in the West Oso Creek subwatershed and possible noncontributing areas in the Oso Creek tributary subwatershed. The rainfall/runoff response for each subwatershed during the March 14-18, 2007, event is shown in figure 7. 


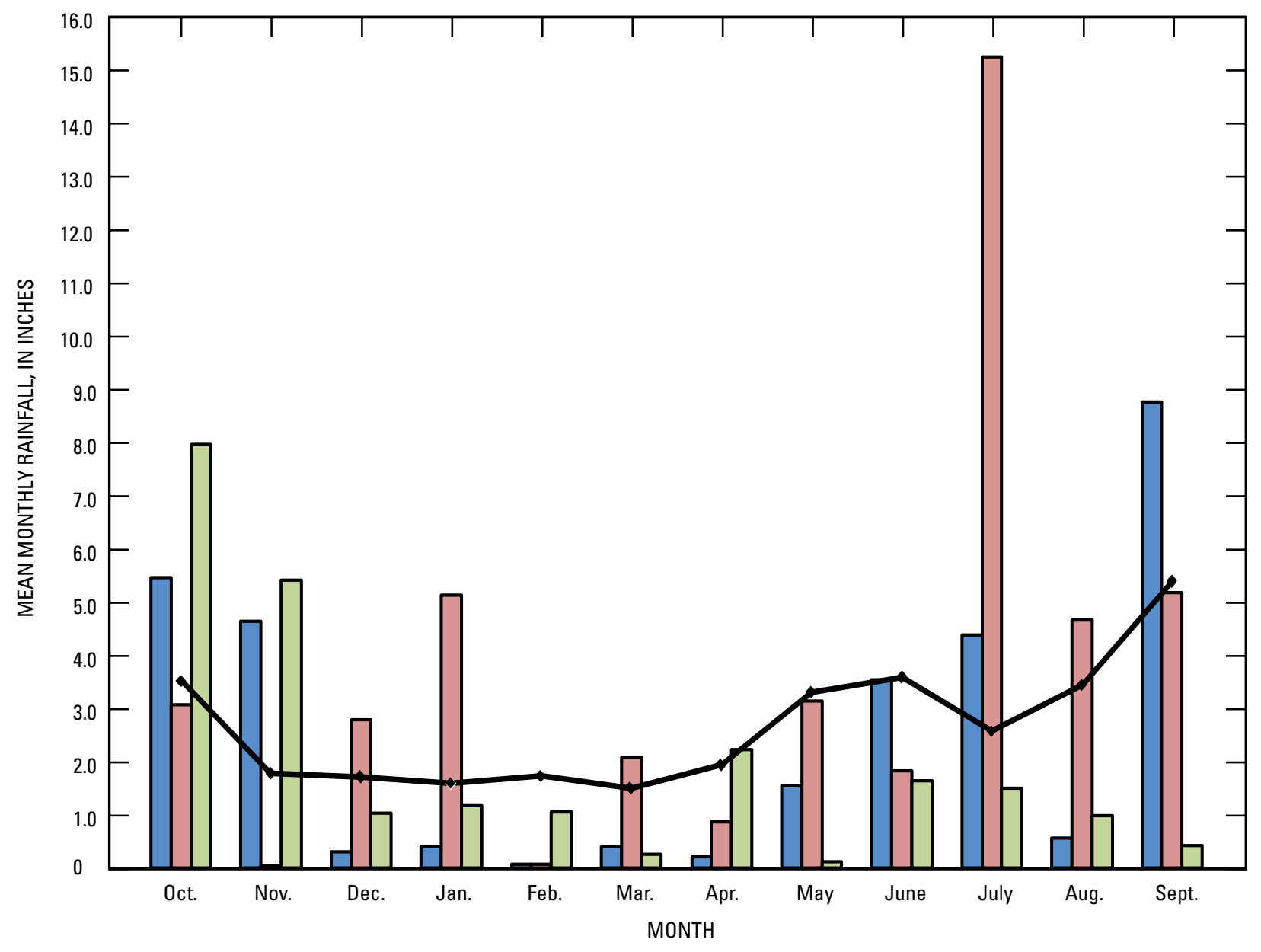

\section{EXPLANATION}

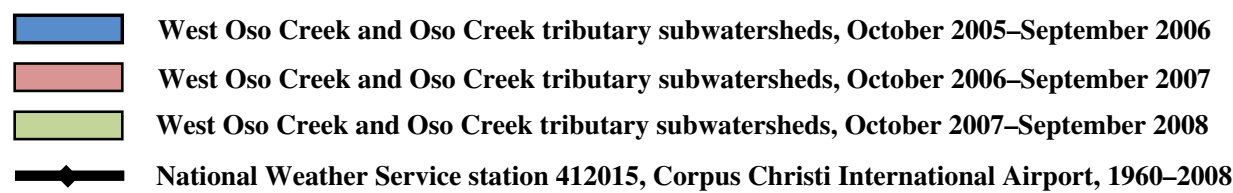

Figure 6. Mean monthly rainfall for National Weather Service station 412015, Corpus Christi International Airport, 1960-2008; and monthly area-weighted rainfall for West 0so Creek and Oso Creek tributary subwatersheds (combined), Nueces County, Texas, water years 2006-08.

\section{Water Quality}

\section{Rainfall}

Seventeen rainfall samples were collected and analyzed for major inorganic ions and nutrients during the study (table 5). During the October 2005-September 2008 study period, $89.17 \mathrm{in}$. of rainfall were recorded at the Texas AgriLife Research station (site 1, fig. 1). The 17 rainfallquality samples represent $31.27 \mathrm{in}$. of rainfall recorded at the Texas AgriLife Research station or about 35 percent of total rainfall during the study period. Thirteen samples were collected during rainfall for which runoff events were sampled. Five rainfall samples were collected during events for which no runoff occurred. These five samples were collected during rainfall events with about $0.5 \mathrm{in}$. of rainfall or less. These samples provided only enough sample volume for nutrient analyses.

Summary statistics for selected rainfall nutrient concentrations are listed in table 6. Most of the nitrogen in rainfall is in the form of dissolved ammonia and dissolved nitrate (the nitrite plus nitrate analysis was predominantly nitrate in these samples, and nitrite was rarely detected; therefore, nitrite plus nitrate is referred to as nitrate in this report), which were 


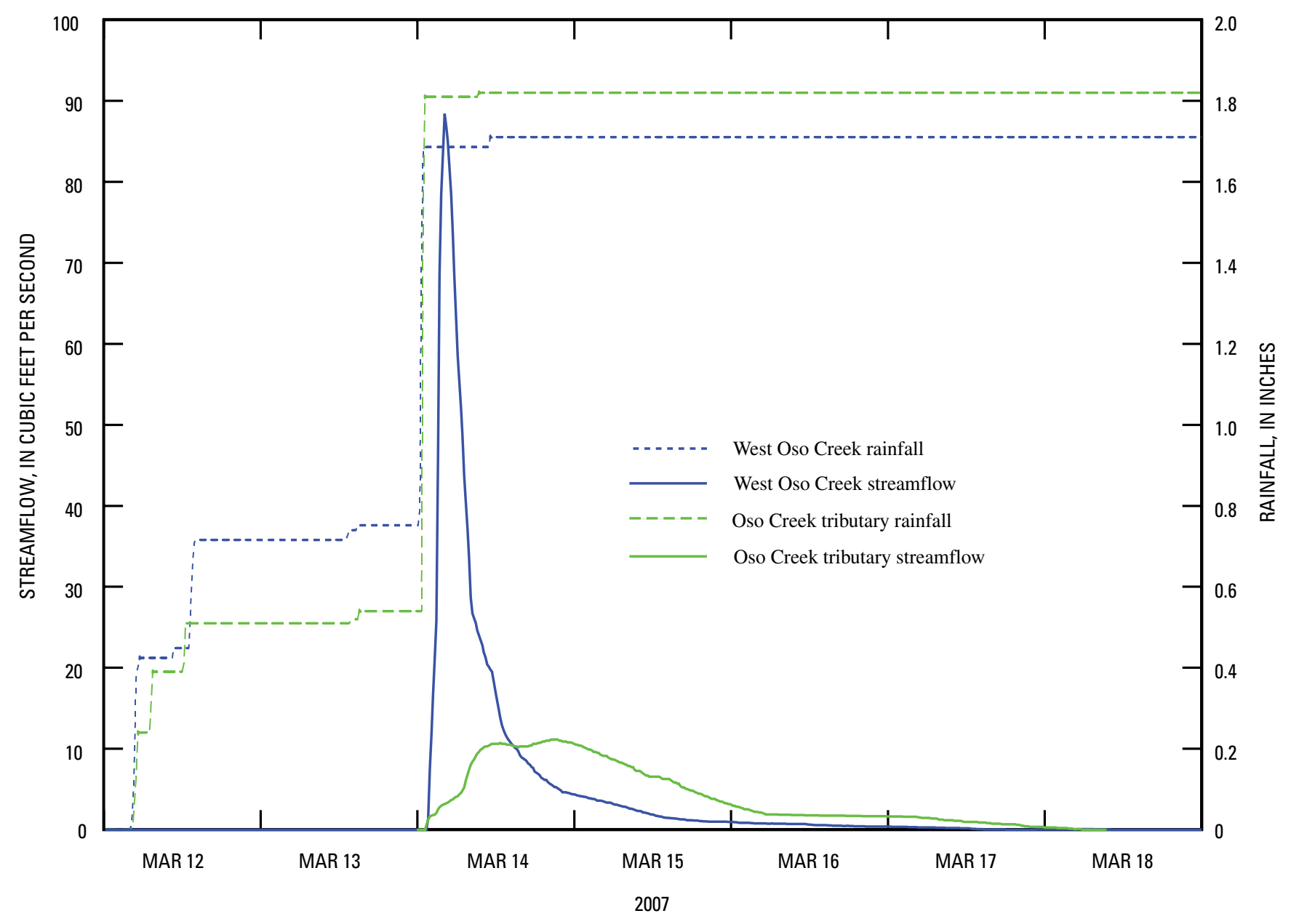

Figure 7. Rainfall/runoff response for West Oso Creek and Oso Creek tributary subwatersheds, Nueces County, Texas, March 12-18, 2007.

detected in all samples. Median concentrations of ammonia and nitrate were 0.17 and 0.12 milligram per liter $(\mathrm{mg} / \mathrm{L})$, respectively. Organic forms of nitrogen were detected in all samples at relatively low concentrations; the median concentration of total organic nitrogen was $0.08 \mathrm{mg} / \mathrm{L}$. Nitrite was detected in less than one-half the samples (table 5); the median concentration was less than $0.002 \mathrm{mg} / \mathrm{L}$ (table 6). Dissolved and total phosphorus were detected in about onehalf of the samples (table 5); the median concentrations were less than $0.006 \mathrm{mg} / \mathrm{L}$ and less than $0.007 \mathrm{mg} / \mathrm{L}$, respectively (table 6).

The deposition of rainfall constituents, in pounds per acre, can be defined as the product of the EMC and rainfall volume and a conversion factor. For rainfall events during which rainfall samples were collected and analyzed, daily deposition of a constituent was computed (using total nitrogen for example) as where

DTN = daily deposition of total nitrogen, in pounds per acre;

EMCTN = total nitrogen rainfall event-mean concentration, in milligrams per liter;

$\mathrm{R}=$ daily rainfall on the study subwatershed, in inches; and

cf $=$ conversion factor of 0.2266 .

For unsampled rainfall events, those for which nitrogen concentrations were not available, daily deposition of nitrogen was estimated from a regression equation that relates daily rainfall and daily nitrogen deposition. Least-squares regression was used with the computed event deposition from sampled events to develop the equation relating daily rainfall and daily deposition. Similar to a previous study of rainfall nitrogen deposition in the Coastal Bend area (Ockerman and Livingston, 1999), rainfall and deposition were logtransformed before performing the regression, then retransformed to original units (Helsel and Hirsch, 2002) to improve
$\mathrm{DTN}=\mathrm{EMCTN} \times \mathrm{R} \times \mathrm{cf}$, 
Table 2. Estimated annual (water years 2006-08) rainfall for West 0so Creek and Oso Creek tributary subwatersheds, Nueces County, Texas, and long-term average annual (water years 1960-2008) rainfall measured at National Weather Service station 412015, Corpus Christi International Airport.

$[--$, not available $]$

\begin{tabular}{lccccc}
\hline Subwatershed & $\begin{array}{c}\text { Oct. 2005-Sept. } \\
\text { 2006 rainfall } \\
\text { (inches) }\end{array}$ & $\begin{array}{c}\text { Oct. 2006-Sept. } \\
\text { 2007 rainfall } \\
\text { (inches) }\end{array}$ & $\begin{array}{c}\text { Oct. 2007-Sept. } \\
\text { 2008 rainfall } \\
\text { (inches) }\end{array}$ & $\begin{array}{c}\text { Average annual } \\
\text { rainfall, 0ct. } \\
\text { 2005-Sept. 2008 } \\
\text { (inches) }\end{array}$ & $\begin{array}{c}\text { Long-term average } \\
\text { annual rainfall, } \\
\text { 1960-2008 } \\
\text { (inches) }\end{array}$ \\
\hline West Oso Creek & 27.91 & 44.87 & 19.61 & 30.80 & - \\
Oso Creek tributary & 31.97 & 45.19 & 29.10 & 35.65 & - \\
$\begin{array}{l}\text { Mean (subwatershed area } \\
\text { weighted) }\end{array}$ & 29.97 & 45.03 & 24.77 & 33.26 & 31.66 \\
\hline
\end{tabular}

Table 3. Annual (water years 2006-08) runoff from West 0so Creek and Oso Creek tributary subwatersheds and long-term average annual (water years 1973-2008) runoff from Oso Creek watershed, Nueces County, Texas.

$[--$, not applicable]

\begin{tabular}{cccccc}
\hline $\begin{array}{c}\text { Subwatershed } \\
\text { or station name } \\
\text { (number) }\end{array}$ & $\begin{array}{c}\text { 0ct. 2005-Sept. } \\
\text { 2006 runoff } \\
\text { (inches) }\end{array}$ & $\begin{array}{c}\text { 0ct. 2006-Sept. } \\
\text { 2007 runoff } \\
\text { (inches) }\end{array}$ & $\begin{array}{c}\text { 0ct. 2007-Sept. } \\
\text { 2008 runoff } \\
\text { (inches) }\end{array}$ & $\begin{array}{c}\text { Average annual } \\
\text { study area } \\
\text { runoff } \\
\text { (inches) }\end{array}$ & $\begin{array}{c}\text { Water years } \\
\text { 1973-2008 average } \\
\text { annual runoff } \\
\text { (inches) }\end{array}$ \\
\hline $\begin{array}{c}\text { West Oso Creek } \\
\text { (station 08211517) }\end{array}$ & 3.19 & 8.19 & 3.14 & 5.69 & -- \\
$\begin{array}{c}\text { Oso Creek tributary } \\
\text { (station 08211525) }\end{array}$ & 2.60 & 4.67 & 2.17 & 3.64 & -- \\
$\begin{array}{c}\text { Oso Creek at Corpus } \\
\text { Christi, Tex. } \\
\text { (station 08211520) }\end{array}$ & 4.37 & 10.9 & 2.18 & 5.82 & 3.90 \\
\hline
\end{tabular}

${ }^{1}$ Runoff at station 08211520 excludes an estimated annual 3 million gallons per day of wastewater discharge during the study period.

the quality of the regression relation. The resulting regression equation is

$$
\text { DTN }=0.09 \times \mathrm{R}^{0.360}
$$

where

DTN = daily deposition of total nitrogen, in pounds per acre; and

$\mathrm{R}=$ daily rainfall on the study subwatershed, in inches.

The coefficient of determination (R-squared) for the regression equation was 0.22 ; the residual standard error was 0.082 pound per acre (lb/acre).

The sampling periods for most rainfall-quality samples collected during the study ranged from 12 to 24 hours and, in most cases, represented the total rainfall for a day. Thus, for purposes of computing deposition of rainfall constituents by using equation 1 and for developing equation 2 relating daily rainfall and daily total nitrogen deposition, the event rainfall for each rainfall sample (table 5) was treated as a daily rainfall total.

Daily total nitrogen deposition for the 17 sampled rainfall events, which was computed by using equation 1 with event (daily) rainfall and total nitrogen sample concentrations (representing EMCs) (total nitrogen unfiltered, table 5), and the corresponding daily total nitrogen deposition, which was estimated by using equation 2 , each relative to daily rainfall, are shown in figure 8.

Daily total nitrogen rainfall deposition for each subwatershed was estimated by using equation 2 with daily rainfall for each subwatershed; estimated monthly and annual deposition, computed from summation of daily deposition, are shown in table 7 . The average (area-weighted) annual total nitrogen deposition for the subwatersheds over the 3-year study period was 4.47 pounds per acre per year [(lb/acre $) / y r]$.

Rainfall deposition of total phosphorus was much less than that of total nitrogen. The median total phosphorus concentration for the 17 rainfall samples (table 6) was less than 
Table 4. Rainfall, runoff, and runoff/rainfall coefficients (ratio of runoff volume to rainfall volume) for selected rainfall and runoff events during water years 2006-08, West 0so Creek and 0so Creek tributary subwatersheds, Nueces County, Texas.

[--, not applicable]

\begin{tabular}{|c|c|c|c|c|c|c|c|c|}
\hline \multirow[b]{2}{*}{ Event date } & \multicolumn{8}{|c|}{ Subwatershed } \\
\hline & $\begin{array}{l}\text { Rainfall } \\
\text { (inches) }\end{array}$ & $\begin{array}{c}\text { Runoff } \\
\text { (inches) }\end{array}$ & $\begin{array}{c}\text { Runoff/ } \\
\text { rainfall } \\
\text { coefficient }\end{array}$ & $\begin{array}{c}\text { Runoff } \\
\text { water- } \\
\text { quality } \\
\text { samples } \\
\text { collected? }\end{array}$ & $\begin{array}{l}\text { Rainfall } \\
\text { (inches) }\end{array}$ & $\begin{array}{c}\text { Runoff } \\
\text { (inches) }\end{array}$ & $\begin{array}{c}\text { Runoff/ } \\
\text { rainfall } \\
\text { coefficient }\end{array}$ & $\begin{array}{c}\text { Runoff } \\
\text { water- } \\
\text { quality } \\
\text { samples } \\
\text { collected? }\end{array}$ \\
\hline Oct. 11-13 & 0.92 & 0 & 0 & No & 7.18 & 0.14 & 0.02 & No \\
\hline Nov. $16-17$ & .49 & .01 & .02 & No & .95 & 0 & 0 & No \\
\hline Nov. 26-29 & 2.62 & .24 & .09 & No & 3.80 & .04 & .01 & No \\
\hline \multicolumn{9}{|l|}{2006} \\
\hline July 6-9 & .88 & .01 & .01 & Yes & 1.73 & .02 & .01 & Yes \\
\hline July 26-27 & 1.34 & .02 & .01 & No & .15 & 0 & 0 & No \\
\hline Aug. 19-20 & .60 & .01 & .02 & No & 0 & 0 & 0 & No \\
\hline Sept. 9-17 & 2.79 & .01 & 0 & Yes & 2.91 & .18 & .06 & Yes \\
\hline Sept. 18-23 & 3.17 & .96 & .30 & Yes & 3.58 & 1.31 & .37 & Yes \\
\hline Sept. 24-Oct. 1 & 2.82 & 1.29 & .46 & No & 2.04 & .85 & .42 & No \\
\hline Oct. $22-25$ & 1.36 & 0 & 0 & No & 1.01 & .06 & .06 & No \\
\hline \multicolumn{9}{|l|}{2007} \\
\hline July 19-24 & 2.07 & 1.26 & .61 & No & 1.76 & .05 & .03 & No \\
\hline July 26-Aug. 8 & 6.37 & 2.32 & .36 & No & 2.13 & .27 & .13 & No \\
\hline Aug. 30-Sept. 2 & 2.45 & 0 & 0 & No & 1.05 & .10 & .10 & Yes \\
\hline Sept. 3-13 & 1.29 & .63 & .49 & No & 1.67 & .18 & .11 & No \\
\hline Sept. 29-Oct. 15 & 3.34 & .32 & .10 & No & 2.43 & .46 & .12 & No \\
\hline \multicolumn{9}{|l|}{2008} \\
\hline Mar. 10-19 & .75 & .03 & .04 & Yes & 1.00 & .06 & .12 & Yes \\
\hline July 23-Aug. 8 & 4.51 & .22 & .05 & Yes & 6.65 & 1.62 & .12 & Yes \\
\hline Aug. 13-31 & 3.21 & 2.81 & .88 & No & 7.21 & .12 & .12 & Yes \\
\hline Sept. 14-22 & .18 & 0 & 0 & No & .50 & .15 & .12 & No \\
\hline Sept. 24-30 & .14 & 0 & 0 & No & .84 & .03 & .03 & No \\
\hline Total-27 events & 63.75 & 13.78 & .22 & -- & 73.26 & 9.43 & .13 & -- \\
\hline $\begin{array}{l}\text { Total-Oct. 2005- } \\
\text { Sept. } 2008\end{array}$ & 92.39 & 13.95 & .15 & -- & 106.26 & 9.45 & .09 & -- \\
\hline
\end{tabular}


Table 5. Event (daily) rainfall, Texas AgriLife Research at Corpus Christi weather station (WS1); and event concentrations of selected constituents in rainfall samples, Texas AgriLife Research at Corpus Christi rainfall-quality sampling station (08211511), Nueces County, Texas, water years 2006-08.

[fltrd, filtered; mg/L, milligrams per liter; N, nitrogen; unfltrd, unfiltered; --, not analyzed; <, less than; E, estimated; P, phosphorus]

\begin{tabular}{|c|c|c|c|c|c|c|c|c|c|c|}
\hline $\begin{array}{c}\text { Sample } \\
\text { date }\end{array}$ & $\begin{array}{l}\text { Event } \\
\text { (daily) } \\
\text { rainfall } \\
\text { (inches) }\end{array}$ & $\begin{array}{c}\text { Calcium, } \\
\text { water, } \\
\text { fltrd } \\
(\mathrm{mg} / \mathrm{L})\end{array}$ & $\begin{array}{l}\text { Magnesium, } \\
\text { water, } \\
\text { fltrd } \\
(\mathrm{mg} / \mathrm{L})\end{array}$ & $\begin{array}{l}\text { Potassium, } \\
\text { water, } \\
\text { fltrd } \\
\text { (mg/L) }\end{array}$ & $\begin{array}{c}\text { Sodium, } \\
\text { water, } \\
\text { fltrd } \\
(\mathrm{mg} / \mathrm{L})\end{array}$ & $\begin{array}{c}\text { Chloride, } \\
\text { water, } \\
\text { fltrd } \\
\text { (mg/L) }\end{array}$ & $\begin{array}{c}\text { Sulfate, } \\
\text { water, } \\
\text { fltrd } \\
(\mathrm{mg} / \mathrm{L})\end{array}$ & $\begin{array}{c}\text { Ammonia } \\
\text { + organic } \\
\text { nitrogen, } \\
\text { water, } \\
\text { fltrd } \\
\text { (mg/L as N) }\end{array}$ & $\begin{array}{c}\text { Ammonia } \\
\text { + organic } \\
\text { nitrogen, } \\
\text { water, } \\
\text { unfltrd } \\
\text { (mg/L as N) }\end{array}$ & $\begin{array}{c}\text { Ammonia } \\
\text { nitrogen, } \\
\text { water, } \\
\text { fltrd } \\
\text { (mg/L as N) }\end{array}$ \\
\hline May 10, 2006 & 1.10 & 1.20 & 1.10 & 0.127 & 0.142 & 1.15 & 2.69 & 1.1 & 1.0 & 0.82 \\
\hline May 14, 2006 & .52 & -- & -- & -- & -- & -- & -- & 2.3 & 1.1 & .75 \\
\hline June 1, 2006 & 9.30 & $<.02$ & $<.008$ & $<.010$ & $<.20$ & .16 & .16 & .17 & E.06 & .04 \\
\hline July 3, 2006 & 1.60 & .14 & .040 & .029 & .32 & .56 & .69 & .28 & .26 & .22 \\
\hline July 6, 2006 & 1.30 & .11 & .027 & .018 & .20 & .35 & .67 & .18 & .18 & .16 \\
\hline July 26, 2006 & 2.40 & .38 & .109 & .046 & .73 & 1.29 & .95 & .29 & .20 & .21 \\
\hline Sept. 11, 2006 & .46 & -- & -- & -- & -- & -- & -- & .13 & 2.0 & .10 \\
\hline Sept. 24, 2006 & 1.80 & .04 & .010 & .031 & .47 & .76 & .64 & .24 & .09 & .08 \\
\hline Oct. 14, 2006 & .14 & -- & -- & -- & -- & -- & -- & .75 & .75 & .71 \\
\hline Jan. 3, 2007 & 1.49 & .09 & .035 & .024 & .34 & .47 & .59 & .17 & .17 & .13 \\
\hline Jan. 24, 2007 & .51 & -- & -- & -- & -- & -- & -- & .18 & .18 & .07 \\
\hline Mar. 14, 2007 & 1.19 & .23 & .044 & .047 & .39 & .54 & .88 & .24 & .24 & .17 \\
\hline May 25, 2007 & 1.52 & .13 & .048 & .046 & .49 & 1.46 & .71 & .20 & .20 & .20 \\
\hline July 2, 2007 & 4.67 & .07 & .028 & .014 & .20 & .35 & .38 & .08 & .08 & .05 \\
\hline Mar. 6, 2008 & 1.24 & .68 & .192 & .091 & 1.47 & 2.76 & 2.18 & .34 & .35 & .30 \\
\hline July 24, 2008 & 1.77 & .29 & .100 & .109 & 1.32 & 2.56 & .63 & E.10 & E.07 & .05 \\
\hline Aug. 18, 2008 & .26 & -- & -- & -- & -- & -- & -- & .40 & .34 & .32 \\
\hline
\end{tabular}

the minimum laboratory reporting level, $0.008 \mathrm{mg} / \mathrm{L}$. The use of equation 1 with mean annual (October 2005-September 2008) rainfall for the subwatersheds (33.26 in., table 2) and the minimum laboratory reporting level to estimate an upper limit of annual total phosphorus deposition for the study period resulted in an estimate of less than 0.07 (lb/acre)/yr.

Values for estimated monthly and annual total nitrogen deposition for water years 2006-07 were revised and compared with the values published in the previous report on hydrologic conditions and water quality of the study subwatersheds (Ockerman, 2008, table 7). Additional data collected during water year 2008, along with previously collected data, were used to revise the relation between rainfall and nitrogen deposition (equation 2), resulting in revised deposition values for water years 2006-07. Previously published values of average annual total nitrogen deposition for 2006-07 were 5.94 and 5.06 (lb/acre)/yr for the West Oso Creek and Oso Creek tributary subwatersheds, respectively. The revised values of average annual total nitrogen deposition for 2006-07 are 5.52 and $4.52(\mathrm{lb} / \mathrm{acre}) / \mathrm{yr}$ for the West Oso Creek and Oso Creek tributary subwatersheds, respectively.

\section{Runoff}

During June 2006-September 2008, 24 event-composite runoff (streamflow) samples were collected at the two subwatershed outlet monitoring sites: 12 samples at West Oso Creek (site 3, fig. 1) and 12 samples at Oso Creek tributary (site 4, fig. 1). Samples were analyzed to characterize the quality of storm runoff from the study subwatersheds. Results of analyses of West Oso Creek and Oso Creek tributary samples are shown in appendixes 2 and 3, respectively.

\section{Nutrients and Major Inorganic lons}

Summary statistics for event concentrations of selected nutrient (nitrogen and phosphorus) and major inorganic ions 
Table 5. Event (daily) rainfall, Texas AgriLife Research at Corpus Christi weather station (WS1); and event concentrations of selected constituents in rainfall samples, Texas AgriLife Research at Corpus Christi rainfall-quality sampling station (08211511), Nueces County, Texas, water years 2006-08-Continued.

\begin{tabular}{|c|c|c|c|c|c|c|c|c|c|c|}
\hline $\begin{array}{c}\text { Sample } \\
\text { date }\end{array}$ & $\begin{array}{c}\text { Event } \\
\text { (daily) } \\
\text { rainfall } \\
\text { (inches) }\end{array}$ & $\begin{array}{c}\text { Nitrite + } \\
\text { nitrate } \\
\text { nitrogen, } \\
\text { water, fltrd } \\
\text { (mg/L as N) }\end{array}$ & $\begin{array}{c}\text { Nitrite } \\
\text { nitrogen, } \\
\text { water, } \\
\text { fltrd } \\
\text { (mg/L } \\
\text { as N) }\end{array}$ & $\begin{array}{c}\text { Organic } \\
\text { nitrogen, } \\
\text { water, } \\
\text { fltrd } \\
(\mathrm{mg} / \mathrm{L} \\
\text { as N) }\end{array}$ & $\begin{array}{c}\text { Organic } \\
\text { nitrogen, } \\
\text { water, } \\
\text { unfltrd } \\
(\mathrm{mg} / \mathrm{L} \\
\text { as N)})^{1}\end{array}$ & $\begin{array}{c}\text { Total } \\
\text { nitrogen, } \\
\text { water, fltrd } \\
(\mathrm{mg} / \mathrm{L} \text { as } \mathrm{N})^{1}\end{array}$ & $\begin{array}{c}\text { Total } \\
\text { nitrogen, } \\
\text { water, } \\
\text { unfltrd } \\
\text { (mg/L as N) }\end{array}$ & $\begin{array}{l}\text { Phospho- } \\
\text { rus, water, } \\
\text { fltrd } \\
\text { (mg/L as } \mathrm{P} \text { ) }\end{array}$ & $\begin{array}{l}\text { Phospho- } \\
\text { rus, water, } \\
\text { unfltrd } \\
\text { (mg/L as } \mathrm{P} \text { ) }\end{array}$ & $\begin{array}{c}\text { Ortho- } \\
\text { phosphate } \\
\text { phosphorus, } \\
\text { water, fltrd } \\
\text { (mg/L as } \mathrm{P} \text { ) }\end{array}$ \\
\hline May 10, 2006 & 1.10 & 0.378 & 0.004 & 0.31 & 0.18 & 1.5 & 1.4 & $<0.004$ & 0.006 & $<0.006$ \\
\hline May 14, 2006 & .52 & .338 & .003 & 1.6 & .31 & 2.6 & 1.4 & .21 & .043 & $<.006$ \\
\hline June 1, 2006 & 9.30 & .029 & $<.002$ & .14 & -- & .20 & E.09 & $<.004$ & .007 & $<.006$ \\
\hline July 3, 2006 & 1.60 & .135 & $<.002$ & .06 & .04 & .41 & .39 & .006 & $<.004$ & $<.006$ \\
\hline July 6, 2006 & 1.30 & .122 & $<.002$ & .02 & .02 & .30 & .30 & $<.004$ & $<.004$ & $<.006$ \\
\hline July 26, 2006 & 2.40 & .149 & $<.002$ & .08 & -- & .44 & .35 & .004 & .005 & $<.006$ \\
\hline Sept. 11, 2006 & .46 & .091 & $<.002$ & .03 & 1.9 & .22 & 2.1 & $<.004$ & $<.004$ & $<.006$ \\
\hline Sept. 24, 2006 & 1.80 & .078 & $<.002$ & .16 & -- & .32 & E.17 & $<.004$ & $<.004$ & $<.006$ \\
\hline Oct. 14, 2006 & .14 & .250 & .004 & .01 & .04 & .96 & 1.0 & .018 & .028 & .013 \\
\hline Jan. 3, 2007 & 1.49 & .064 & .002 & .03 & .04 & .22 & .24 & .005 & $<.008$ & .003 \\
\hline Jan. 24, 2007 & .51 & .066 & .002 & .05 & .10 & .19 & .24 & $<.006$ & $<.008$ & $<.006$ \\
\hline Mar. 14, 2007 & 1.19 & .092 & .001 & .05 & .07 & .31 & .33 & $<.006$ & .005 & $<.006$ \\
\hline May 25, 2007 & 1.52 & .102 & .002 & .09 & .005 & .39 & .30 & $<.006$ & $<.008$ & $<.006$ \\
\hline July 2, 2007 & 4.67 & .057 & $<.002$ & .08 & .03 & .19 & E.13 & $<.006$ & .004 & $<.006$ \\
\hline Mar. 6, 2008 & 1.24 & .132 & E.002 & .11 & .12 & .47 & .48 & .008 & .009 & E.003 \\
\hline July 24,2008 & 1.77 & E.013 & $<.002$ & E.07 & E.03 & E.11 & E.08 & E.004 & E.005 & E.004 \\
\hline Aug. 18, 2008 & .26 & .134 & $<.002$ & .15 & .09 & .53 & .47 & E.005 & E.007 & E.005 \\
\hline
\end{tabular}

${ }^{1}$ Concentration of constituent not analyzed directly but computed from other analyzed constituents.

(calcium, potassium, chloride, and sulfate) for each subwatershed are shown in table 8. Nutrient concentrations in runoff were greater at the West Oso Creek site than at the Oso Creek tributary site. Major inorganic ion concentrations were greater at the Oso Creek tributary site than at the West Oso Creek site.

The results of Wilcoxon rank-sum tests (Helsel and Hirsch, 2002), done to indicate whether event-median concentrations of respective constituents at the two subwatershed sites are significantly different at the .05 level, are listed in table 9. The tests indicate that event-median concentrations of selected forms of nitrogen are significantly greater at the West Oso Creek subwatershed. Event-median concentrations of major inorganic ions in runoff were all significantly greater at the Oso Creek tributary subwatershed. There was no significant difference in the total phosphorus median concentrations between the two subwatersheds; however, dissolved orthophosphate concentrations were greater in the Oso Creek tributary subwatershed.
The load of a constituent in runoff (streamflow) is the mass of a given constituent transported past a site on a stream during a specified period (Huber, 1993, p. 14.2). Daily nutrient loads were computed for the study subwatershed outlet sites from runoff and concentration data. For runoff events that were sampled and for which EMCs were determined, the daily constituent load at a particular site is computed as

$$
\mathrm{L}=\mathrm{EMC} \times \mathrm{R} \times \mathrm{cf} \text {, }
$$

where

$\mathrm{L}=$ constituent load, in pounds per day;

$\mathrm{EMC}=$ event-mean concentration during runoff event, in milligrams per liter or micrograms per liter;

$\mathrm{R}$ = runoff, in acre-feet per day; and

$\mathrm{cf}=$ conversion factor, 2.719 for concentrations in milligrams per liter or $2.719 \times 10^{-3}$ for concentrations in micrograms per liter. 
Table 6. Summary statistics for event rainfall, Texas AgriLife Research at Corpus Christi weather station (WS1); and event concentrations of selected nutrients in rainfall samples, Texas AgriLife Research at Corpus Christi rainfall-quality sampling station (08211511), Nueces County, Texas, water years 2006-08.

[in., inches; mg/L, milligrams per liter; --, not applicable; <, less than]

\begin{tabular}{|c|c|c|c|c|c|}
\hline Constituent & Number of samples & Mean & Median & Minimum & Maximum \\
\hline Rainfall (in.) & 17 & 1.84 & 1.30 & 0.14 & 9.30 \\
\hline Ammonia + organic nitrogen, dissolved $(\mathrm{mg} / \mathrm{L})$ & 17 & .42 & .24 & .08 & 2.30 \\
\hline Ammonia + organic nitrogen, total $(\mathrm{mg} / \mathrm{L})$ & 17 & .40 & .20 & .06 & 2.00 \\
\hline Ammonia nitrogen, dissolved (mg/L) & 17 & .26 & .17 & .04 & .82 \\
\hline Nitrite + nitrate nitrogen, dissolved $(\mathrm{mg} / \mathrm{L})$ & 17 & .17 & .12 & .013 & .378 \\
\hline Nitrite nitrogen, dissolved $(\mathrm{mg} / \mathrm{L})$ & 17 & -- & $<.002$ & $<.002$ & .004 \\
\hline Nitrate nitrogen, dissolved $(\mathrm{mg} / \mathrm{L})^{1}$ & 17 & .17 & .12 & .013 & .78 \\
\hline Organic nitrogen, total $(\mathrm{mg} / \mathrm{L})^{2}$ & 17 & .20 & .08 & .02 & 1.9 \\
\hline Nitrogen, total $(\mathrm{mg} / \mathrm{L})^{3}$ & 17 & .56 & .33 & .17 & 2.10 \\
\hline Phosphorus, dissolved (mg/L) & 17 & $<.006$ & $<.006$ & $<.004$ & .021 \\
\hline Phosphorus, total (mg/L) & 17 & -- & $<.007$ & $<.004$ & .043 \\
\hline Orthophosphate phosphorus, dissolved (mg/L) & 17 & $<.006$ & $<.006$ & $<.006$ & .013 \\
\hline
\end{tabular}

${ }^{1}$ Computed as difference between nitrite plus nitrate nitrogen and nitrite nitrogen.

${ }^{2}$ Computed as difference between ammonia plus total organic nitrogen (unfiltered) and ammonia nitrogen.

${ }^{3}$ Computed as sum of nitrite plus nitrate nitrogen and ammonia plus total organic nitrogen (unfiltered).

Event-median concentrations of selected nutrients in samples at each site (table 9) were used to estimate runoff loads for unsampled events at each site. During water years 2006-08, sampled runoff events represent about 35 percent of total runoff from the West Oso Creek subwatershed. About 65 percent of the runoff was unsampled. Sampled and unsampled runoff percentages from the Oso Creek tributary subwatershed were about 76 percent and 24 percent, respectively. The percentage of total runoff sampled in the West Oso Creek subwatershed was less than that sampled in the Oso Creek tributary subwatershed because three of the four runoff events with the greatest runoff volume in West Oso Creek were not sampled. The three runoff events with the greatest runoff volume in Oso Creek tributary were sampled.

Constituent yield, a measure of the load-producing characteristics of a watershed, is computed by dividing the runoff load by the drainage area of the watershed:

$$
\mathrm{Y}=\mathrm{L} / \mathrm{DA},
$$

where

$\mathrm{Y}=$ constituent yield, in pounds per acre per month (or year);

$\mathrm{L}=$ constituent load exiting the watershed, in pounds per month (or year); and

DA = contributing drainage area of the watershed, in acres.
Estimated monthly and annual loads of selected nutrients in runoff from each of the study subwatersheds are listed in table 10, and the corresponding annual runoff yields are listed in table 11. Monthly and annual nutrient loads were highly variable, depending on storm runoff. Large storm events contributed most of the runoff constituent loads. As a result of large storms in July 2007, about 39 percent of the total nitrogen runoff load and 44 percent of the total phosphorus runoff load for the entire study period for both subwatersheds occurred in this 1-month period.

Nitrogen yields from the West Oso Creek subwatershed were greater than yields from the Oso Creek tributary subwatershed for two reasons: (1) West Oso Creek subwatershed runoff was greater, and (2) nitrogen concentrations generally were greater for the West Oso Creek subwatershed. Average total nitrogen yield from the West Oso Creek subwatershed was $2.62(\mathrm{lb} / \mathrm{acre}) / \mathrm{yr}$ for the 3-year study period. Average total nitrogen yield from the Oso Creek tributary subwatershed for the 3-year period was less than one-half that for the West Oso Creek subwatershed, 0.839 (lb/acre)/yr.

Average total phosphorus yield from the West Oso Creek subwatershed was greater than that from the Oso Creek tributary subwatershed. Although the median runoff concentrations for total phosphorus were about the same for each subwatershed, greater runoff at West Oso Creek resulted in greater runoff yields. The average annual total phosphorus yields for West Oso Creek and Oso Creek tributary were 0.644 and 0.419 (lb/acre)/yr, respectively (table 11). 


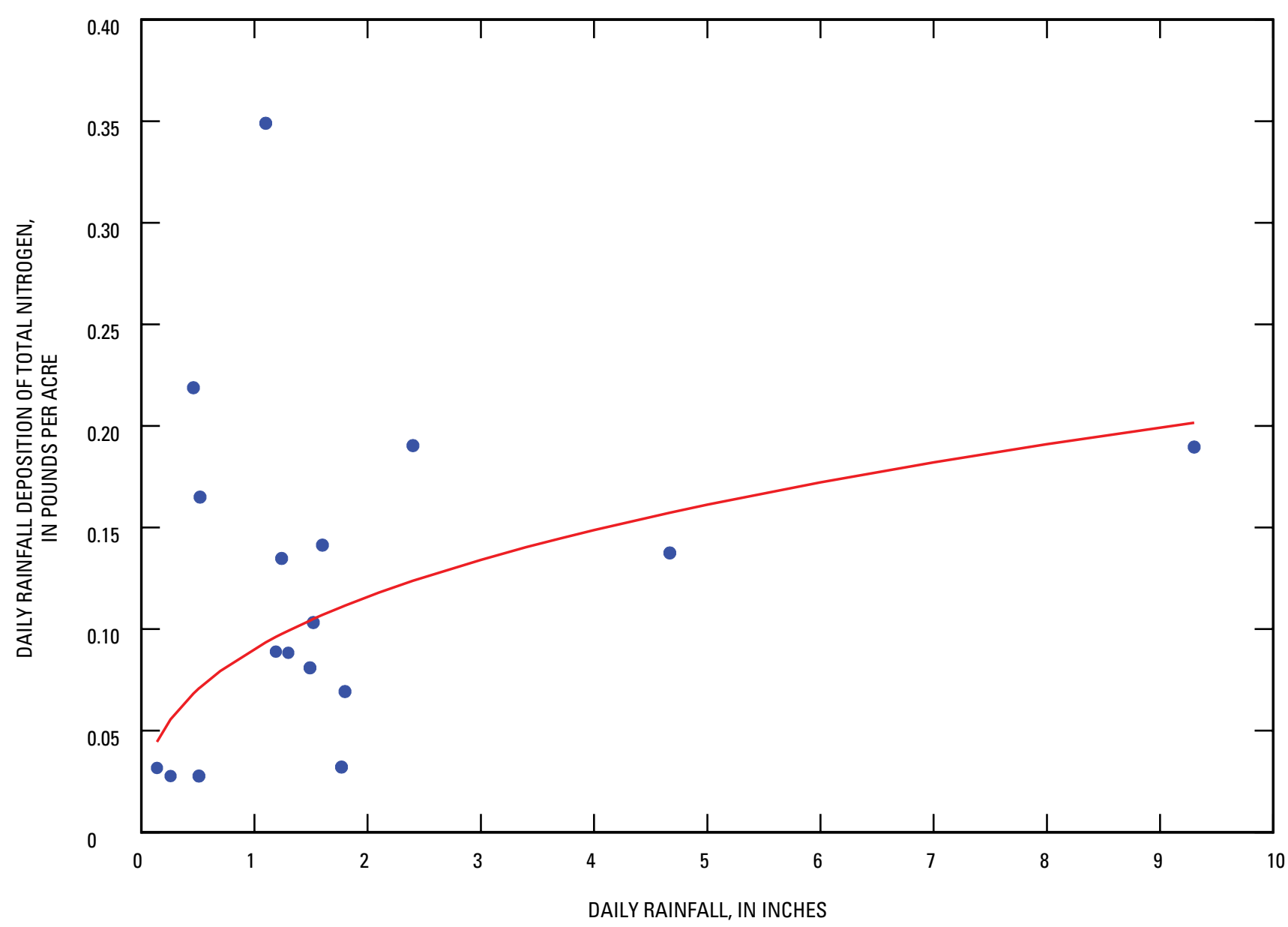

EXPLANATION

- Daily deposition computed from event (daily) rainfall and sample (event-mean) concentration (table 5, total nitrogen, unfiltered)

Daily deposition estimated by regression with daily rainfall

Figure 8. Daily deposition of total nitrogen computed from event (daily) rainfall and sample concentrations and estimated by regression with daily rainfall, each relative to daily rainfall, for sampled rainfall events, 0so Creek watershed, Nueces County, Texas, water years 2006-08.

Estimated runoff loads and yields of nitrogen and phosphorus for water years 2006-07 were revised from estimates published in the previous report on the study subwatersheds (Ockerman, 2008). Runoff-quality data collected since the previous report, along with previous data, were used to estimate median concentrations that were then used to compute runoff loads during unsampled events. This resulted in revisions to 2006-07 load and yield estimates. The previously published 2006-07 average annual runoff yield (weighted average of both study subwatersheds) for total nitrogen was $1.78(\mathrm{lb} / \mathrm{acre}) / \mathrm{yr}$. The revised estimate of average annual runoff yield for 2006-07 is 1.91 (lb/acre)/yr.

Information on fertilizer nutrient application in study subwatershed croplands for 2006-08 was compiled by
Texas AgriLife Research (Dr. Bobby Eddleman, Texas AgriLife Research, written commun., 2007) and the Natural Resources Conservation Service (John Freeman, U.S. Department of Agriculture, Natural Resources Conservation Service, Nueces County, Tex., written commun., 2009). Annual runoff yields of total nitrogen and total phosphorus were compared to nutrient inputs from fertilizer applications and rainfall deposition (table 12).

Nitrogen input from fertilizer is much larger than nitrogen that either enters the study area subwatersheds through rainfall deposition or exits the subwatersheds in runoff. Average (area-weighted for both subwatersheds) annual application of fertilizer-based nitrogen was 64.2 (lb/acre)/ $\mathrm{yr}$, compared to 4.47 (lb/acre)/yr from rainfall deposition 
Table 7. Estimated monthly and annual total nitrogen rainfall deposition on West 0 so Creek and 0 so Creek tributary subwatersheds, Nueces County, Texas, water years 2006-08.

[In pounds per acre]

\begin{tabular}{|c|c|c|c|c|c|c|c|c|c|c|c|c|c|}
\hline Year & Oct. & Nov. & Dec. & Jan. & Feb. & Mar. & Apr. & May & June & July & Aug. & Sept. & Annual \\
\hline \multicolumn{14}{|c|}{ West Oso Creek subwatershed } \\
\hline 2006 & 0.48 & 0.37 & 0.12 & 0.23 & 0.15 & 0.19 & 0.14 & 0.47 & 0.39 & 0.73 & 0.27 & 1.03 & 4.57 \\
\hline 2007 & .38 & .05 & .52 & .68 & .13 & .20 & .44 & .53 & .52 & 1.39 & .95 & .68 & 6.47 \\
\hline 2008 & .26 & .25 & .20 & .54 & .16 & .23 & .31 & .23 & .12 & .60 & .67 & .19 & 3.76 \\
\hline \multicolumn{14}{|c|}{ Oso Creek tributary subwatershed } \\
\hline 2006 & .59 & .43 & .18 & .17 & 0 & .09 & 0 & .31 & .26 & .42 & .08 & .94 & 3.48 \\
\hline 2007 & .62 & 0 & .51 & .72 & .07 & .24 & .29 & .33 & .41 & 1.06 & .76 & .56 & 5.56 \\
\hline 2008 & .20 & .27 & .06 & .38 & .05 & .18 & .14 & .21 & .13 & .60 & .55 & .13 & 3.03 \\
\hline
\end{tabular}

Table 8. Summary statistics for event concentrations of selected nutrients and major inorganic ions in runoff samples, West Oso Creek (station 08211517) and 0so Creek tributary (station 08211525) subwatersheds, Nueces County, Texas, water years 2006-08.

[mg/L, milligrams per liter; --, not available; <, less than laboratory reporting level]

\begin{tabular}{|c|c|c|c|c|c|}
\hline Constituent & $\begin{array}{c}\text { Number of } \\
\text { samples }\end{array}$ & Mean & Median & Minimum & Maximum \\
\hline \multicolumn{6}{|c|}{ West 0 so Creek subwatershed } \\
\hline Ammonia nitrogen, dissolved (mg/L) & 12 & -- & 0.040 & $<0.02$ & 0.228 \\
\hline Nitrite + nitrate nitrogen, dissolved $(\mathrm{mg} / \mathrm{L})$ & 12 & 1.00 & .61 & .22 & 3.26 \\
\hline Ammonia + organic nitrogen, total $(\mathrm{mg} / \mathrm{L})$ & 12 & 2.50 & 2.20 & .75 & 7.0 \\
\hline Organic nitrogen, total $(\mathrm{mg} / \mathrm{L})^{1}$ & 12 & 2.40 & 2.07 & .74 & 6.6 \\
\hline Nitrogen, total $(\mathrm{mg} / \mathrm{L})^{2}$ & 12 & 3.50 & 3.18 & .97 & 9.0 \\
\hline Phosphorus, total (mg/L) & 12 & .71 & .62 & .29 & 1.5 \\
\hline Calcium, dissolved (mg/L) & 11 & 14.2 & 14.4 & 8.9 & 18.4 \\
\hline Potassium, dissolved (mg/L) & 11 & 4.86 & 4.07 & 3.24 & 9.73 \\
\hline Chloride, dissolved (mg/L) & 11 & 2.33 & 1.61 & .97 & 6.03 \\
\hline Sulfate, dissolved (mg/L) & 11 & 1.99 & 1.60 & .90 & 3.90 \\
\hline \multicolumn{6}{|c|}{ Oso Creek tributary subwatershed } \\
\hline Ammonia nitrogen, dissolved (mg/L) & 12 & -- & .021 & $<.020$ & .172 \\
\hline Nitrite + nitrate nitrogen, dissolved $(\mathrm{mg} / \mathrm{L})$ & 12 & -- & .20 & $<.04$ & 1.37 \\
\hline Ammonia + organic nitrogen, total $(\mathrm{mg} / \mathrm{L})$ & 12 & 1.28 & 1.04 & .79 & 2.5 \\
\hline Organic nitrogen, total $(\mathrm{mg} / \mathrm{L})^{1}$ & 12 & 1.26 & 1.03 & .78 & 2.3 \\
\hline Nitrogen, total $(\mathrm{mg} / \mathrm{L})^{2}$ & 12 & 1.68 & 1.26 & .84 & 3.57 \\
\hline Phosphorus, total (mg/L) & 12 & .66 & .61 & .41 & 1.02 \\
\hline Calcium, dissolved (mg/L) & 11 & 18.7 & 18.9 & 10.3 & 28.5 \\
\hline Potassium, dissolved (mg/L) & 11 & 8.58 & 8.31 & 4.82 & 16.9 \\
\hline Chloride, dissolved (mg/L) & 11 & 11.9 & 11.0 & 1.97 & 23.8 \\
\hline Sulfate, dissolved (mg/L) & 11 & 6.98 & 6.23 & 1.30 & 17.4 \\
\hline
\end{tabular}

\footnotetext{
${ }^{1}$ Computed as difference between ammonia plus total organic nitrogen (unfiltered) and ammonia nitrogen.
}

${ }^{2}$ Computed as sum of nitrite plus nitrate nitrogen and ammonia plus organic nitrogen, total. 
Table 9. Event-median concentrations of selected nutrients and major inorganic ions in runoff samples, West 0 so Creek (station 08211517) and Oso Creek tributary (station 08211525) subwatersheds, Nueces County, Texas, water years 2006-08; and results of Wilcoxon rank-sum tests to indic ate whether event-median concentrations for the two subwatersheds are significantly different.

[mg/L, milligrams per liter]

\begin{tabular}{|c|c|c|c|c|}
\hline \multirow{2}{*}{ Constituent } & \multicolumn{2}{|c|}{$\begin{array}{l}\begin{array}{l}\text { Subwatershed event-median concentration } \\
(\mathrm{mg} / \mathrm{L})\end{array} \\
\end{array}$} & \multirow{2}{*}{$p$-value } & \multirow{2}{*}{$\begin{array}{c}\text { Concentrations } \\
\text { significantly different } \\
\text { at } .05 \text { level? }\end{array}$} \\
\hline & West Oso Creek & Oso Creek tributary & & \\
\hline Ammonia nitrogen, dissolved & 0.040 & 0.021 & .03 & Yes \\
\hline Nitrite + nitrate nitrogen, dissolved & .61 & .20 & .02 & Yes \\
\hline Ammonia + organic nitrogen, total & 2.20 & 1.04 & .01 & Yes \\
\hline Organic nitrogen, total ${ }^{1}$ & 2.07 & 1.03 & .01 & Yes \\
\hline Nitrogen, total ${ }^{2}$ & 3.18 & 1.26 & .01 & Yes \\
\hline Phosphorus, total & .62 & .61 & .34 & No \\
\hline Orthophosphate phosphorus, dissolved & .284 & .418 & .0068 & Yes \\
\hline Calcium, dissolved & 14.4 & 18.9 & .02 & Yes \\
\hline Potassium, dissolved & 4.07 & 8.31 & .0009 & Yes \\
\hline Chloride, dissolved & 1.61 & 11.0 & .0001 & Yes \\
\hline Sulfate, dissolved & 1.60 & 6.23 & .001 & Yes \\
\hline
\end{tabular}

${ }^{1}$ Computed as difference between ammonia plus total organic nitrogen (unfiltered) and ammonia nitrogen.

${ }^{2}$ Computed as sum of nitrite plus nitrate nitrogen and ammonia plus total organic nitrogen (unfiltered).

and 1.72 (lb/acre)/yr in runoff. Annual rainfall deposition of nitrogen exceeds runoff yields because most rainfall does not contribute to runoff, even though for most periods of runoff, nitrogen runoff yields exceed rainfall nitrogen deposition. The average annual runoff yield of total nitrogen represents about 2.5 percent of nitrogen applied as fertilizer and nitrogen entering the subwatersheds through rainfall deposition. Also, nearly all of the nitrogen applied as fertilizer and entering the subwatersheds through rainfall deposition is in the form of ammonia and nitrate. Nitrogen exiting the study subwatersheds in runoff is mostly organic nitrogen (table 11).

As with nitrogen, fertilizer inputs of phosphorus are much greater than phosphorus runoff yields. Average annual fertilizer input of phosphorus was 13.2 (lb/acre)/yr (table 12). Average runoff of total phosphorus was 0.530 (lb/acre)/yr, or about 4.0 percent of the phosphorus applied as fertilizer. Average phosphorus input from rainfall was relatively small, estimated to be less than 0.07 (lb/acre)/yr. Fertilizer is applied as soluble orthophosphate. Most of the runoff phosphorus also was in the form of orthophosphate (table 11).

\section{Suspended Sediment}

Results of analyses for 26 samples of suspended sediment in runoff are listed in table 13. Twelve samples were collected at West Oso Creek (station 08211517), and 14 samples were collected at Oso Creek tributary (station 08211525). The samples were analyzed for concentration and for percentage silt and clay, by weight (particle size less than $0.062 \mathrm{~mm}$ ). The sediment concentrations from these samples are not EMCs but represent sediment concentrations at the time of sample collection. Sediment concentrations, loads, and yields are a function of streamflow and other factors, including soil erodibility, rainfall intensity and duration, and crop growth stage and tillage practices (U.S. Department of Agriculture, Agricultural Research Service, 2006). Generally, suspendedsediment concentrations, loads, and yields were larger for the West Oso Creek subwatershed than for the Oso Creek tributary subwatershed. Considering all samples from both sites, the percentage of silt and clay was 96 or greater for 23 of the 26 samples.

For each subwatershed (sites 3, 4, fig. 1), a regression equation was developed relating suspended-sediment load ([instantaneous] tons per day) to streamflow (cubic feet per second). The regression relations for each site are shown in figure 9. The equations and R-squared and residual standard error values are listed in table 14 .

From these equations, instantaneous sediment loads were computed for each subwatershed outlet site and aggregated to obtain monthly and annual loads (table 15). As with runoff and nutrient loads, suspended-sediment loads were highly variable by month. More than 75 percent of the entire sediment load from the study subwatersheds occurred during the 3 months of September 2006, July 2007, and August 2008. 
Table 10. Estimated monthly and annual runoff loads of selected nutrients from West Oso Creek (station 08211517) and Oso Creek tributary (station 08211525) subwatersheds, Nueces County, Texas, water years 2006-08.

[In pounds]

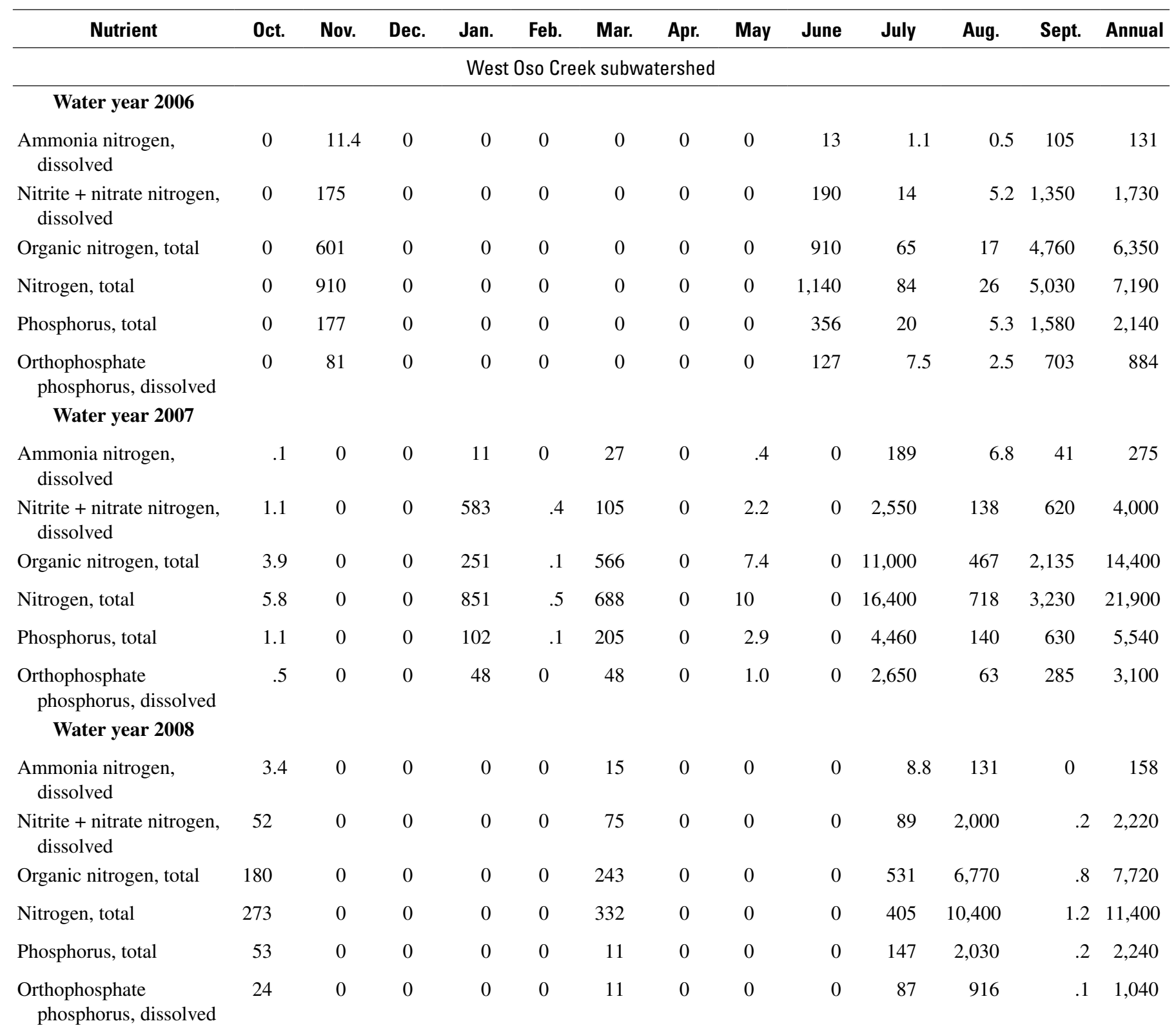

Annual and average annual suspended-sediment yields for the subwatersheds (table 16) were computed from the loads and watershed drainage areas. Suspended-sediment yields from the West Oso Creek subwatershed were more than three times greater than those from the Oso Creek tributary subwatershed. The average suspended-sediment yield from the West Oso Creek subwatershed was 522 (lb/acre)/yr. The average suspended-sediment yield from the Oso Creek tributary subwatershed was 139 (lb/acre)/yr. One reason the West Oso Creek sediment yield is greater is that the subwatershed produced more runoff than the Oso Creek tributary subwatershed. Also, because runoff response is more rapid for the
West Oso Creek subwatershed than for the Oso Creek tributary subwatershed, larger peak flows can generate higher stream velocities and, potentially, greater sediment concentrations and loads. The West Oso Creek monitoring station is located at the edge of an agricultural field with no pasture buffer or structural controls to mitigate sediment runoff to the monitoring site. Also, part of West Oso Creek upstream from the monitoring site is not a well-defined channel, but a watercourse that flows through (over) cultivated cropland. In contrast, the Oso Creek tributary upstream from the monitoring site on that stream is surrounded by a buffer area of grassland along the sides of the channel. 
Table 10. Estimated monthly and annual runoff loads of selected nutrients from West Oso Creek (station 08211517) and Oso Creek tributary (station 08211525) subwatersheds, Nueces County, Texas, water years 2006-07-Continued.

\begin{tabular}{|c|c|c|c|c|c|c|c|c|c|c|c|c|c|}
\hline Nutrient & Oct. & Nov. & Dec. & Jan. & Feb. & Mar. & Apr. & May & June & July & Aug. & Sept. & Annual \\
\hline \multicolumn{14}{|c|}{ Oso Creek tributary subwatershed } \\
\hline \multicolumn{14}{|l|}{ Water year 2006} \\
\hline $\begin{array}{l}\text { Ammonia nitrogen, } \\
\text { dissolved }\end{array}$ & 3.3 & 1.0 & 0 & 0 & 0 & 0 & 0 & 0 & 2.3 & 0.3 & 0 & 63 & 70 \\
\hline $\begin{array}{l}\text { Nitrite + nitrate nitrogen, } \\
\text { dissolved }\end{array}$ & 33 & 9.9 & 0 & 0 & 0 & 0 & 0 & 0 & 24 & 1.3 & 0 & 559 & 627 \\
\hline Organic nitrogen, total & 168 & 51 & 0 & 0 & 0 & 0 & 0 & 0 & 135 & 25 & 0 & 2,530 & 2,910 \\
\hline Nitrogen, total & 206 & 62 & 0 & 0 & 0 & 0 & 0 & 0 & 162 & 26 & 0 & 3,520 & 3,980 \\
\hline Phosphorus, total & 100 & 30 & 0 & 0 & 0 & 0 & 0 & 0 & 88 & 17 & 0 & 1,450 & 1,680 \\
\hline $\begin{array}{l}\text { Orthophosphate } \\
\text { phosphorus, dissolved } \\
\text { Water year } 2007\end{array}$ & 69 & 21 & 0 & 0 & 0 & 0 & 0 & 0 & 57 & 12 & 0 & 877 & 1,040 \\
\hline $\begin{array}{l}\text { Ammonia nitrogen, } \\
\text { dissolved }\end{array}$ & 1.9 & 0 & 0 & 9.0 & .3 & 16 & 0 & .6 & 0 & 74 & 3.3 & 12 & 117 \\
\hline $\begin{array}{l}\text { Nitrite + nitrate nitrogen, } \\
\text { dissolved }\end{array}$ & 18 & 0 & 0 & 311 & 6.2 & 95 & 0 & 14.8 & 0 & 662 & 28 & 107 & 1,240 \\
\hline Organic nitrogen, total & 90 & 0 & 0 & 426 & 7.4 & 228 & 0 & 26 & 0 & 4,070 & 165 & 590 & 5,600 \\
\hline Nitrogen, total & 110 & 0 & 0 & 749 & 13.7 & 333 & 0 & 23.1 & 0 & 4,660 & 190 & 714 & 6,790 \\
\hline Phosphorus, total & 53 & 0 & 0 & 190 & 3.3 & 93 & 0 & 18 & 0 & 2,780 & 80 & 343 & 3,560 \\
\hline $\begin{array}{l}\text { Orthophosphate } \\
\text { phosphorus, dissolved } \\
\text { Water year } 2008\end{array}$ & 37 & 0 & 0 & 118 & 2.2 & 35 & 0 & 6.5 & 0 & 2,330 & 58 & 237 & 2,820 \\
\hline $\begin{array}{l}\text { Ammonia nitrogen, } \\
\text { dissolved }\end{array}$ & 4.5 & 0 & 0 & 0 & 0 & 13 & 0 & 0 & 0 & 38 & 3.6 & 4.6 & 64 \\
\hline $\begin{array}{l}\text { Nitrite }+ \text { nitrate nitrogen, } \\
\text { dissolved }\end{array}$ & 45 & 0 & 0 & 1.1 & 0 & 101 & 0 & 0 & 0 & 96 & 30 & 43 & 316 \\
\hline Organic nitrogen, total & 232 & 0 & 0 & .6 & 0 & 147 & 0 & .1 & 0 & 1,830 & 165 & 221 & 2,600 \\
\hline Nitrogen, total & 284 & 0 & 0 & .7 & 0 & 258 & 0 & .1 & 0 & 1,600 & 146 & 271 & 2,560 \\
\hline Phosphorus, total & 138 & 0 & 0 & .3 & 0 & 75 & 0 & 0 & 0 & 975 & 93 & 131 & 1,410 \\
\hline $\begin{array}{l}\text { Orthophosphate } \\
\text { phosphorus, dissolved }\end{array}$ & 95 & 0 & 0 & .2 & 0 & 41 & 0 & 0 & 0 & 776 & 82 & 90 & 1,080 \\
\hline
\end{tabular}

Estimated runoff loads of suspended sediment for water years 2006-07 were revised from estimates published in the previous report on the study subwatersheds (Ockerman, 2008). Additional suspended-sediment data collected since the previous report were used to revise the relations used to estimate suspended-sediment loads (fig. 9). The 2006-07 average annual runoff yield for suspended sediment in the West Oso Creek subwatershed was revised to 608 (lb/acre)/ yr, compared with the previous estimate of 582 (lb/acre)/ yr. The 2006-07 average annual runoff yield for suspended sediment in the Oso Creek tributary subwatershed was revised to $159(\mathrm{lb} / \mathrm{acre}) / \mathrm{yr}$, compared with the previous estimate of 257 (lb/acre)/yr.

\section{Pesticides}

Runoff samples were analyzed for a suite of 88 pesticides. The pesticide analysis schedules requested from the USGS NWQL included some pesticides not used in the subwatersheds, and some pesticides used in the subwatersheds were not included in the 88 requested analyses because some analyses were not available through the NWQL. Also, a complete list of pesticides applied by agricultural users in the subwatersheds was not available at the beginning of the study. Texas AgriLife Research (Dr. Bobby Eddleman, Texas AgriLife Research, written commun., 2007), with assistance from the Natural Resources Conservation Service 
Table 11. Estimated annual and average annual runoff yields of selected nutrients from West 0so Creek (station 08211517) and 0so Creek tributary (station 08211525) subwatersheds, Nueces County, Texas, water years 2006-08.

[In pounds per acre per year]

\begin{tabular}{lcccc}
\hline \multicolumn{1}{c}{ Nutrient } & Water year 2006 & Water year 2007 & Water year 2008 & $\begin{array}{c}\text { Water years 2006-08 } \\
\text { average }\end{array}$ \\
\hline Ammonia nitrogen, dissolved & West Oso Creek subwatershed (5,145 acres) & & 0.037 \\
Nitrite + nitrate nitrogen, dissolved & 0.026 & 0.053 & 0.031 & .515 \\
Organic nitrogen, total & .336 & .778 & .432 & 1.84 \\
Nitrogen, total & 1.23 & 2.80 & 1.50 & 2.62 \\
Phosphorus, total & 1.39 & 4.26 & 2.22 & .644 \\
Orthophosphate phosphorus, dissolved & .416 & 1.08 & .435 & .325 \\
& .172 & .602 & .202 & .016 \\
Ammonia nitrogen, dissolved & 0so Creek tributary subwatershed (5,287 acres) & & .138 \\
Nitrite + nitrate nitrogen, dissolved & .013 & .022 & .012 & .701 \\
Organic nitrogen, total & .119 & .235 & .060 & .839 \\
Nitrogen, total & .550 & 1.06 & .492 & .419 \\
Phosphorus, total & .753 & 1.28 & .484 & .311 \\
Orthophosphate phosphorus, dissolved & .318 & .673 & .267 & .204 \\
\hline
\end{tabular}

(John Freeman, U.S. Department of Agriculture, Natural Resources Conservation Service, Nueces County, Tex., written commun., 2009), compiled information on pesticide application rates for the study subwatersheds during 2005-08. The pesticides that were reported as applied in the study subwatersheds during 2005-08 are listed in table 17. Table 17 also indicates applied pesticides that were not included in the laboratory analyses of runoff samples.

Pesticides detected in runoff samples and concentration summary statistics are listed in table 18. Pesticide analytical results for all samples are listed in appendixes 2 and 3 . Laboratory analyses indicated detection of 32 pesticide compounds ( 24 herbicides and 8 insecticides) in 24 runoff samples collected from the two subwatershed outlet sites combined. At the West Oso Creek site, 23 pesticides were detected (19 herbicides and 4 insecticides) and at the Oso Creek tributary site, 24 pesticides were detected (18 herbicides and 6 insecticides). Of the 32 pesticides detected during the study, 14 were detected only once, either at the West Oso Creek site or the Oso Creek tributary site. All of these 14 single detections were at low concentrations (near the minimum laboratory reporting level). Two herbicides were detected in all samples from both sites: atrazine and atrazine degradation byproduct CIAT. Also, glyphosate and glyphosate degradation byproduct aminomethylphosphonic acid (AMPA) were detected in all samples collected during water years 2006-07. Glyphosate and AMPA were not included in the sample analysis for samples collected during water year 2008. Herbicides 2,4-D and pendimethalin were detected in more than 50 percent of all samples at both sites.

Pesticide runoff loads and yields were computed by using equations 3 and 4, respectively, for atrazine, glyphosate, and pendimethalin. For sampled events, sample concentrations were used to estimate runoff loads. For unsampled runoff, seasonal event-median concentrations (table 19) were used to estimate runoff loads. The preharvest season comprises January-June; the harvest/postharvest season comprises JulySeptember. No samples were collected from October through December. Monthly and annual estimates of selected pesticide runoff loads are listed in table 20.

Annual and average annual application rates and runoff yields for selected pesticides are listed in table 21. Similar to results for nutrients and suspended sediment, runoff yields of the herbicides atrazine, glyphosate, and pendimethalin were greater for the West Oso Creek subwatershed than for the Oso Creek tributary subwatershed. Of all pesticides detected in runoff, the highest runoff yields were for glyphosate, $0.012(\mathrm{lb} / \mathrm{acre}) / \mathrm{yr}$ for the West Oso Creek subwatershed and 0.001 (lb/acre)/yr for the Oso Creek tributary subwatershed. Average annual runoff yields of atrazine were 0.002 and 0.0003 (lb/acre)/yr, respectively, from the West Oso Creek and Oso Creek tributary subwatersheds. Comparison of applications and runoff yields indicates that, for water years 2006-08, about 0.9 percent of glyphosate applied to the West Oso Creek 


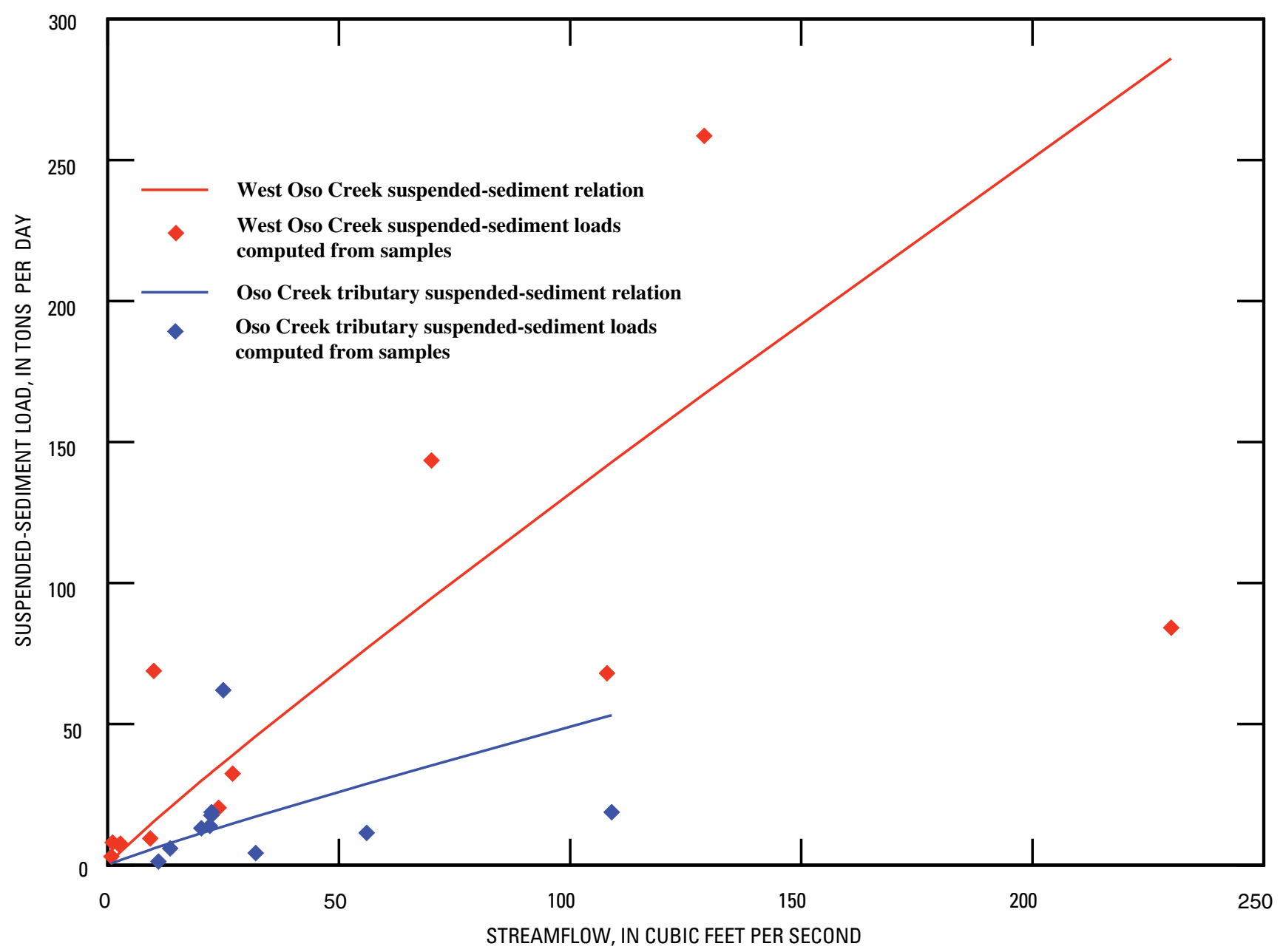

Figure 9. Relations between suspended-sediment load and streamflow for West Oso Creek (station 08211517) and Oso Creek tributary (station 082115725) subwatersheds, Nueces County, Texas, water years 2006-08.

subwatershed croplands was detected in runoff. For the Oso Creek tributary subwatershed, about 0.08 percent of applied glyphosate was detected in runoff. The percentages of applied atrazine in runoff were about 0.4 and 0.05 , respectively, in the West Oso Creek and Oso Creek tributary subwatersheds. Applied pendimethalin in runoff was estimated to be 0.08 and 0.008 percent, respectively, in the West Oso Creek and Oso Creek tributary subwatersheds.

Estimated runoff loads and yields of selected pesticides for water years 2006-07 were revised from estimates published in the previous report on the study subwatersheds (Ockerman, 2008). Runoff-quality data collected since the previous report, along with previous data, were used to estimate median concentrations that were then used to compute runoff loads during unsampled events. This resulted in revisions to 2006-07 load and yield estimates. The 2006-07 average annual runoff yield for atrazine was unchanged for the West Oso Creek subwatershed. The 2006-07 average annual runoff yield for atrazine for the Oso Creek tributary subwatershed was revised to 0.00023 (lb/acre)/yr, compared with a previous estimate of 0.00012 (lb/acre)/yr. No additional sample data were collected for glyphosate since the previous study, so runoff load and yield estimates for glyphosate did not change from the previous report.

\section{Bacteria}

Seventeen bacteria samples were collected during the study, 10 from the West Oso Creek subwatershed outlet site and 7 from the Oso Creek tributary subwatershed outlet site (table 22). Summary statistics of bacteria sample analysis results are shown in table 23. Table 23 also shows TSWQS for bacteria in Oso Bay and Oso Creek, TCEQ segments 2485 and 2485A, respectively (Texas Commission on Environmental Quality, 2006).

Similar to other constituents, bacteria densities were greater at the West Oso Creek subwatershed than at the Oso Creek tributary subwatershed. Bacteria loads and yields were not estimated because bacteria samples were collected near the beginning of runoff events, and concentrations 
Table 12. Fertilizer applications, rainfall deposition, and runoff yields of total nitrogen and total phosphorus for West 0 so Creek and Oso Creek tributary subwatersheds, Nueces County, Texas, water years 2006-08.

[lb/acre, pounds per acre; (lb/acre)/yr, pounds per acre per year; <, less than]

\begin{tabular}{|c|c|c|c|}
\hline Subwatershed and period & Fertilizer application & Rainfall deposition & Runoff yield \\
\hline \multicolumn{4}{|c|}{ Total nitrogen } \\
\hline Water year 2006, lb/acre & 71.3 & 4.57 & 1.39 \\
\hline Water year 2008, lb/acre & 59.6 & 3.76 & 2.22 \\
\hline 2006-08 average, (lb/acre)/yr & 65.5 & 4.93 & 2.62 \\
\hline \multicolumn{4}{|l|}{ Oso Creek tributary } \\
\hline Water year 2008, lb/acre & 57.5 & 3.03 & .484 \\
\hline 2006-08 average, $(\mathrm{lb} / \mathrm{acre}) / \mathrm{yr}$ & 63.0 & 4.02 & .839 \\
\hline Area-weighted average, both subwatersheds, $2006-08,(\mathrm{lb} / \mathrm{acre}) / \mathrm{yr}$ & 64.2 & 4.47 & 1.72 \\
\hline
\end{tabular}

Total phosphorus

\section{West Oso Creek}

Water year 2006, lb/acre

Water year 2007, lb/acre

2006-08 average, (lb/acre)/yr
Water year 2008, lb/acre
15.4

14.3

11.1

13.6

14.6

12.9

10.8

12.8

13.2
$<.06$

.416

1.08

.435

.644

\section{Oso Creek tributary}

Water year 2006, lb/acre

Water year 2007, lb/acre

Water year 2008, lb/acre

2006-08 average, (lb/acre)/yr

Area-weighted average, both subwatersheds, 2006-08, (lb/acre)/yr and infrequent conditions, the resulting effect on downstream receiving waters (Oso Bay and Oso Creek) is not known. However, the relatively large bacteria densities (compared to TSWQS) indicate that runoff from these subwatersheds has the potential to contribute bacteria to Oso Bay and
Oso Creek. might not be representative of bacteria conditions throughout the runoff events. Most sample bacteria densities exceeded TSWQS (table 23). The TSWQS listed in table 23 apply to Oso Bay and Oso Creek and are not technically applicable to the study subwatersheds. Also, because runoff and associated bacteria densities represent relatively brief 
Table 13. Results of analyses for samples of suspended sediment in runoff from West Oso Creek (station 08211517) and 0so Creek tributary (station 08211525) subwatersheds, Nueces County, Texas, water years 2006-08.

[ft ${ }^{3} / \mathrm{s}$, cubic feet per second; $\mathrm{mg} / \mathrm{L}$, milligrams per liter]

\begin{tabular}{|c|c|c|c|c|}
\hline Sample collection date & Collection time & $\begin{array}{c}\text { Discharge } \\
\left(\mathrm{ft}^{3} / \mathbf{s}\right)\end{array}$ & $\begin{array}{c}\text { Concentration } \\
\text { (mg/L) }\end{array}$ & $\begin{array}{c}\text { Percentage silt and clay, } \\
\text { by weight }\end{array}$ \\
\hline \multicolumn{5}{|c|}{ West 0so Creek subwatershed } \\
\hline \multirow[t]{3}{*}{ June 1, 2006} & 1400 & 129 & 745 & 96 \\
\hline & 1140 & 27 & 447 & 99 \\
\hline & 1600 & 24 & 315 & 97 \\
\hline July 3,2006 & 1717 & .81 & 1,400 & 99 \\
\hline \multirow[t]{2}{*}{ Jan. 4, 2007} & 1145 & 2.8 & 1,005 & 100 \\
\hline & 1530 & 2.5 & 1,070 & 100 \\
\hline Jan. 25, 2007 & 0900 & 9.2 & 383 & 97 \\
\hline Mar. 14, 2007 & 1430 & 10 & 2,560 & 99 \\
\hline July 2, 2007 & 1845 & 108 & 234 & 72 \\
\hline July 3,2007 & 0945 & 230 & 136 & 73 \\
\hline Mar. 11, 2008 & 0445 & 1.1 & 2,720 & 99 \\
\hline July 24,2008 & 1300 & 70 & 762 & 99 \\
\hline \multicolumn{5}{|c|}{ Oso Creek tributary subwatershed } \\
\hline June 1,2006 & 1710 & 25 & 923 & 97 \\
\hline \multirow[t]{4}{*}{ Sept. 15, 2006} & 1400 & 22.4 & 293 & 99 \\
\hline & 1505 & 22.5 & 311 & 99 \\
\hline & 1730 & 22.1 & 234 & 99 \\
\hline & 1930 & 20.3 & 239 & 96 \\
\hline Sept. 16, 2006 & 0730 & 13.5 & 163 & 96 \\
\hline Jan. 4, 2007 & 1415 & 8.1 & 484 & 97 \\
\hline Jan. 25, 2007 & 0700 & 24.8 & 200 & 100 \\
\hline Mar. 14, 2007 & 1700 & 10 & 1,504 & 98 \\
\hline July 3, 2007 & 1930 & 32 & 50 & 99 \\
\hline July 4, 2007 & 0830 & 56 & 76 & 100 \\
\hline Aug. 30, 2007 & 0800 & 11 & 44 & 99 \\
\hline Mar. 11, 2008 & 1400 & 3.8 & 882 & 99 \\
\hline July 24,2008 & 1700 & 109 & 64 & 87 \\
\hline
\end{tabular}

Table 14. Regression equations relating suspended-sediment load to streamflow for West Oso Creek (station 08211517) and Oso Creek tributary (station 08211525) subwatersheds, Nueces County, Texas, water years 2006-08.

[L, load in tons per day; Q, streamflow in cubic feet per second]

\begin{tabular}{lccc}
\hline \multicolumn{1}{c}{ Subwatershed } & Equation & $\begin{array}{c}\text { Coefficient of determination } \\
\text { (R-squared) }\end{array}$ & $\begin{array}{c}\text { Residual standard error } \\
\text { (tons per day) }\end{array}$ \\
\hline West Oso Creek & $\mathrm{L}=1.82 \times \mathrm{Q}^{0.93}$ & 0.80 & 71 \\
Oso Creek tributary & $\mathrm{L}=0.71 \times \mathrm{Q}^{0.92}$ & .64 & 20 \\
\hline
\end{tabular}


Table 15. Estimated monthly and annual runoff suspended-sediment loads, West 0so Creek (station 08211517) and Oso Creek tributary (station 08211525) subwatersheds, Nueces County, Texas, water years 2006-08.

[In tons]

\begin{tabular}{|c|c|c|c|c|c|c|c|c|c|c|c|c|c|}
\hline $\begin{array}{l}\text { Water } \\
\text { year }\end{array}$ & Oct. & Nov. & Dec. & Jan. & Feb. & Mar. & Apr. & May & June & July & Aug. & Sept. & Annual \\
\hline \multicolumn{14}{|c|}{ West Oso Creek subwatershed } \\
\hline 2006 & 0 & 74 & 0 & 0 & 0 & 0 & 0 & 0 & 187 & 9.2 & 1.3 & 627 & 898 \\
\hline 2007 & .6 & 0 & 0 & 54 & .04 & 36 & 0 & 1.0 & 0 & 1,827 & 63 & 253 & 2,230 \\
\hline 2008 & 25 & 0 & 0 & 0 & 0 & 10 & 0 & 0 & 0 & 66 & 798 & 0 & 899 \\
\hline \multicolumn{14}{|c|}{ Oso Creek tributary subwatershed } \\
\hline 2006 & 16 & 5.8 & 0 & 0 & 0 & 0 & 0 & 0 & 10 & 2.7 & 0 & 266 & 300 \\
\hline 2007 & 10 & 0 & 0 & 45 & 1.0 & 11 & 0 & 2.4 & 0 & 399 & 14 & 60 & 542 \\
\hline 2008 & 26 & 0 & 0 & 0 & 0 & 9 & 0 & 0 & 0 & 178 & 21 & 23 & 257 \\
\hline
\end{tabular}

Table 16. Annual and average annual runoff yields of suspended sediment, West Oso Creek (station 08211517) and Oso Creek tributary (station 08211525) subwatersheds, Nueces County, Texas, water years 2006-08.

[In pounds per acre per year]

\begin{tabular}{lcccc}
\hline \multicolumn{1}{c}{ Subwatershed } & Water year 2006 & Water year 2007 & Water year 2008 & $\begin{array}{c}\text { Water years } \\
\text { 2006-08 average }\end{array}$ \\
\hline West Oso Creek & 349 & 867 & 350 & 522 \\
Oso Creek tributary & 113 & 205 & 97 & 139 \\
\hline
\end{tabular}

Table 17. Pesticides used in West 0 so Creek and Oso Creek tributary subwatersheds, Nueces County, Texas, water years 2006-08.

[* indicates chemical not included in runoff-sample laboratory analysis]

\begin{tabular}{lll}
\hline \multicolumn{1}{c}{ Herbicides } & \multicolumn{1}{c}{ Insecticides } & $\begin{array}{c}\text { Defoliants, desicants, } \\
\text { growth regulators }\end{array}$ \\
\hline 2,4-D & $*$ Acephate & *Ethephon \\
Atrazine & $*$ Acetamiprid & $*$ Mepiquat chloride \\
Glyphosate & $*$ Cyfluthrin & *Mepiquat pentaborate \\
Glufosinate-ammonium & $*$ Deltamethrin & $*$ Thidiazuron \\
*Prosulfuron & Dicrotophos & $*$ Thidiazuron + diuron \\
Pendimethalin & Imidacloprid & $*$ Paraquat chloride \\
Prometryn & Malathion & \\
Trifluralin & Myclobutanil ${ }^{1}$ & \\
& Propoxur ${ }^{2}$ & \\
& $*$ Thiamethoxam & \\
& Zeta-cypermethrin & \\
\hline
\end{tabular}

\footnotetext{
${ }^{1}$ Fungicide used primarily for residential applications.

${ }^{2}$ Insecticide used primarily for residential applications.
} 
Table 18. Summary statistics of concentrations of selected pesticides in runoff samples from West 0so Creek (station 08211517) and Oso Creek tributary (station 08211525) subwatersheds, Nueces County, Texas, water years 2006-08.

[ $\mu \mathrm{g} / \mathrm{L}$, micrograms per liter; --, not computed; <, less than]

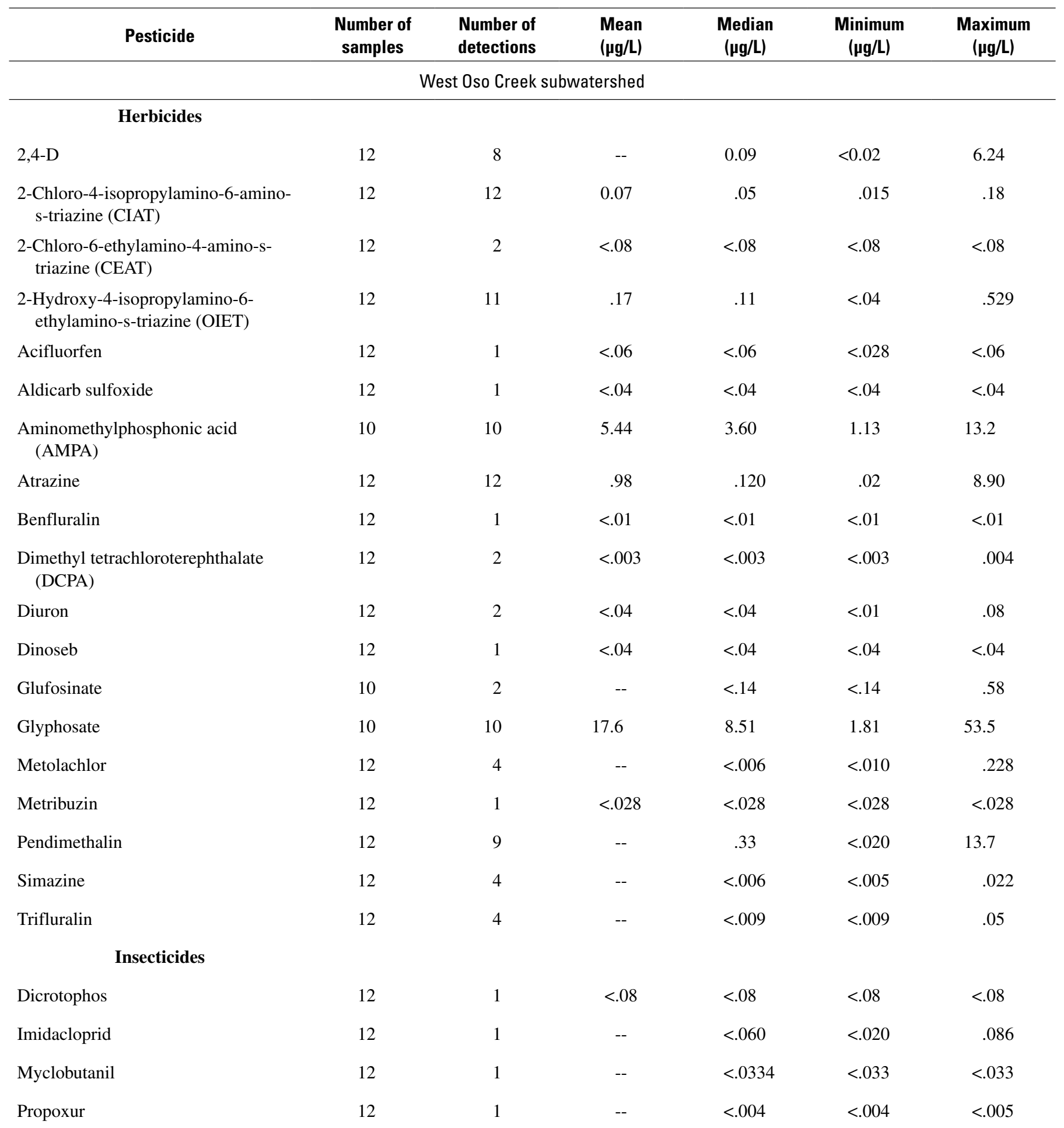


Table 18. Summary statistics of concentrations of selected pesticides in runoff samples from West 0 so Creek (station 08211517) and Oso Creek tributary (station 08211525) subwatersheds, Nueces County, Texas, water years 2006-08-Continued.

\begin{tabular}{|c|c|c|c|c|c|c|}
\hline Pesticide & $\begin{array}{l}\text { Number of } \\
\text { samples }\end{array}$ & $\begin{array}{l}\text { Number of } \\
\text { detections }\end{array}$ & $\begin{array}{l}\text { Mean } \\
(\mu \mathrm{g} / \mathrm{L})\end{array}$ & $\begin{array}{c}\text { Median } \\
(\mu \mathrm{g} / \mathrm{L})\end{array}$ & $\underset{(\mu \mathrm{g} / \mathrm{L})}{\operatorname{Minimum}}$ & $\begin{array}{c}\text { Maximum } \\
(\mu \mathrm{g} / \mathrm{L})\end{array}$ \\
\hline \multicolumn{7}{|c|}{ Oso Creek tributary subwatershed } \\
\hline \multicolumn{7}{|l|}{ Herbicides } \\
\hline 2,4-D & 12 & 8 & -- & $<0.05$ & $<0.02$ & 1.23 \\
\hline $\begin{array}{l}\text { 2-Chloro-4-isopropylamino-6-amino- } \\
\text { s-triazine (CIAT) }\end{array}$ & 12 & 12 & 0.107 & .062 & .009 & .562 \\
\hline $\begin{array}{l}\text { 2-Chloro-6-ethylamino-4-amino-s- } \\
\text { triazine (CEAT) }\end{array}$ & 12 & 3 & -- & $<.08$ & $<.08$ & .11 \\
\hline $\begin{array}{l}\text { 2-Hydroxy-4-isopropylamino-6- } \\
\text { ethylamino-s-triazine (OIET) }\end{array}$ & 12 & 12 & .257 & .200 & .021 & .902 \\
\hline 3,4 Dichloroaniline & 12 & 1 & -- & $<.004$ & $<.004$ & .006 \\
\hline $\begin{array}{l}\text { Aminomethylphosphonic acid } \\
\text { (AMPA) }\end{array}$ & 8 & 8 & .90 & .60 & .35 & 1.94 \\
\hline Atrazine & 12 & 12 & 1.94 & .254 & .012 & 10.5 \\
\hline Bromacil & 12 & 1 & -- & $<.04$ & $<.02$ & .05 \\
\hline Carbaryl & 12 & 4 & $<.02$ & $<.02$ & $<.02$ & $<.02$ \\
\hline $\begin{array}{l}\text { Dimethyl tetrachloroterephthalate } \\
\text { (DCPA) }\end{array}$ & 12 & 1 & $<.003$ & $<.003$ & $<.003$ & .004 \\
\hline Dicamba & 12 & 1 & -- & $<.04$ & $<.04$ & .97 \\
\hline Diuron & 12 & 3 & -- & $<.04$ & $<.02$ & .10 \\
\hline Glyphosate & 8 & 8 & 2.56 & 1.08 & .59 & 10.6 \\
\hline Metolachlor & 12 & 3 & -- & $<.010$ & $<.006$ & .008 \\
\hline Pendimethalin & 12 & 8 & -- & .040 & $<.012$ & .144 \\
\hline Simazine & 12 & 5 & -- & $<.006$ & $<.005$ & .064 \\
\hline Terbuthylazine & 12 & 1 & -- & $<.01$ & $<.01$ & .02 \\
\hline Trifluralin & 12 & 4 & -- & $<.009$ & $<.009$ & .054 \\
\hline \multicolumn{7}{|l|}{ Insecticides } \\
\hline Azinphos-methyl & 9 & 1 & $<.05$ & $<.05$ & $<.05$ & $<.08$ \\
\hline Dicrotophos & 12 & 1 & $<.08$ & $<.08$ & $<.08$ & $<.08$ \\
\hline Malathion & 12 & 2 & -- & $<.016$ & $<.016$ & 2.64 \\
\hline Fipronil sulfide & 12 & 1 & -- & $<.013$ & $<.013$ & $<.013$ \\
\hline Malaoxon & 12 & 1 & -- & $<.039$ & $<.039$ & .049 \\
\hline Myclobutanil & 12 & 2 & -- & $<.033$ & $<.010$ & $<.033$ \\
\hline
\end{tabular}


Table 19. Event-median concentrations of selected pesticides in runoff samples from West Oso Creek (station 08211517) and 0so Creek tributary (station 08211525) subwatersheds, Nueces County, Texas, by season (preharvest or harvest/postharvest), water years 2006-08, used to estimate runoff loads for unsampled events.

[In micrograms per liter]

\begin{tabular}{|c|c|c|c|}
\hline \multirow[b]{2}{*}{ Pesticide } & \multicolumn{2}{|c|}{ Season median concentration } & \multirow{2}{*}{$\begin{array}{c}\text { Median concentration } \\
\text { all samples }\end{array}$} \\
\hline & $\begin{array}{l}\text { Preharvest } \\
\text { (Jan.-June) }\end{array}$ & $\begin{array}{c}\text { Harvest/postharvest } \\
\text { (July-Sept.) }\end{array}$ & \\
\hline Atrazine & 0.198 & 0.097 & 0.120 \\
\hline Glyphosate & 5.10 & 12.6 & 8.51 \\
\hline Atrazine & 1.88 & .194 & .254 \\
\hline Glyphosate & 1.34 & 1.08 & 1.08 \\
\hline Pendimethalin & .091 & .020 & .040 \\
\hline
\end{tabular}

Table 20. Estimated monthly and annual runoff loads of selected pesticides from West Oso Creek (station 08211517) and Oso Creek tributary (station 08211525) subwatersheds, Nueces County, Texas, water years 2006-08.

[In pounds]

\begin{tabular}{|c|c|c|c|c|c|c|c|c|c|c|c|c|c|}
\hline Pesticide & Oct. & Nov. & Dec. & Jan. & Feb. & Mar. & Apr. & May & June & July & Aug. & Sept. & Annual \\
\hline \multicolumn{14}{|c|}{ West Oso Creek subwatershed } \\
\hline \multicolumn{14}{|c|}{ Water year 2006} \\
\hline Glyphosate & 0 & 3.60 & 0 & 0 & 0 & 0 & 0 & 0 & 1.37 & .581 & .104 & 21.5 & 27.2 \\
\hline Pendimethalin & 0 & .06 & 0 & 0 & 0 & 0 & 0 & 0 & .015 & .043 & .002 & .728 & .85 \\
\hline Glyphosate & .023 & 0 & 0 & .448 & 0 & .703 & 0 & .153 & 0 & 92.5 & 2.85 & 12.8 & 109 \\
\hline Pendimethalin & .0004 & 0 & 0 & .483 & 0 & .003 & 0 & .007 & 0 & 1.20 & .05 & .21 & 1.95 \\
\hline \multicolumn{14}{|c|}{ Water year 2008} \\
\hline Atrazine & .008 & 0 & 0 & 0 & 0 & .035 & 0 & 0 & 0 & .023 & .317 & 0 & .38 \\
\hline \multicolumn{14}{|c|}{ Water year 2006} \\
\hline Atrazine & .032 & .010 & 0 & 0 & 0 & 0 & 0 & 0 & .170 & .007 & 0 & .086 & .30 \\
\hline Glyphosate & .176 & .053 & 0 & 0 & 0 & 0 & 0 & 0 & .055 & .014 & 0 & 2.34 & 2.64 \\
\hline Pendimethalin & .003 & .001 & 0 & 0 & 0 & 0 & 0 & 0 & .002 & .001 & 0 & .134 & .14 \\
\hline \multicolumn{14}{|c|}{ Water year 2007} \\
\hline Atrazine & .017 & 0 & 0 & .009 & 0 & .897 & 0 & .004 & 0 & .82 & .091 & .170 & 2.01 \\
\hline Glyphosate & .096 & 0 & 0 & .335 & .005 & .364 & 0 & .024 & 0 & 8.24 & .234 & .677 & 10.0 \\
\hline Pendimethalin & .002 & 0 & 0 & .056 & .001 & .013 & 0 & 0 & 0 & .085 & .063 & .071 & .290 \\
\hline \multicolumn{14}{|c|}{ Water year 2008} \\
\hline
\end{tabular}


Table 21. Estimated annual and average annual application rates and runoff yields of selected pesticides from West 0 so Creek and Oso Creek tributary subwatersheds, Nueces County, Texas, water years 2006-08.

[In pounds per acre per year]

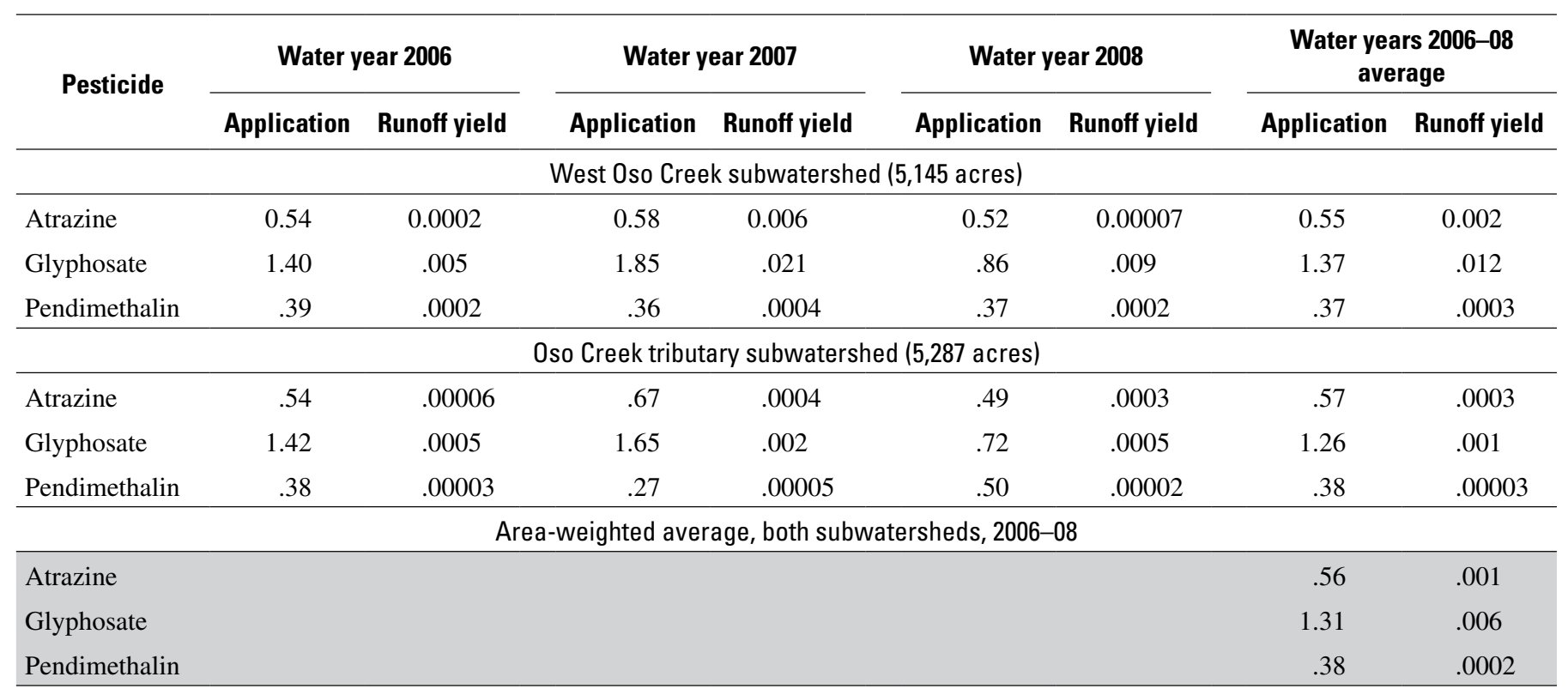

Table 22. Bacteria densities in runoff samples from West Oso Creek (station 08211517) and Oso Creek tributary (station 08211525) subwatersheds, Nueces County, Texas, water years 2006-08.

[CFU/100 mL, colony forming units per 100 milliliters; E. coli, Escherichia coli; --, not analyzed for]

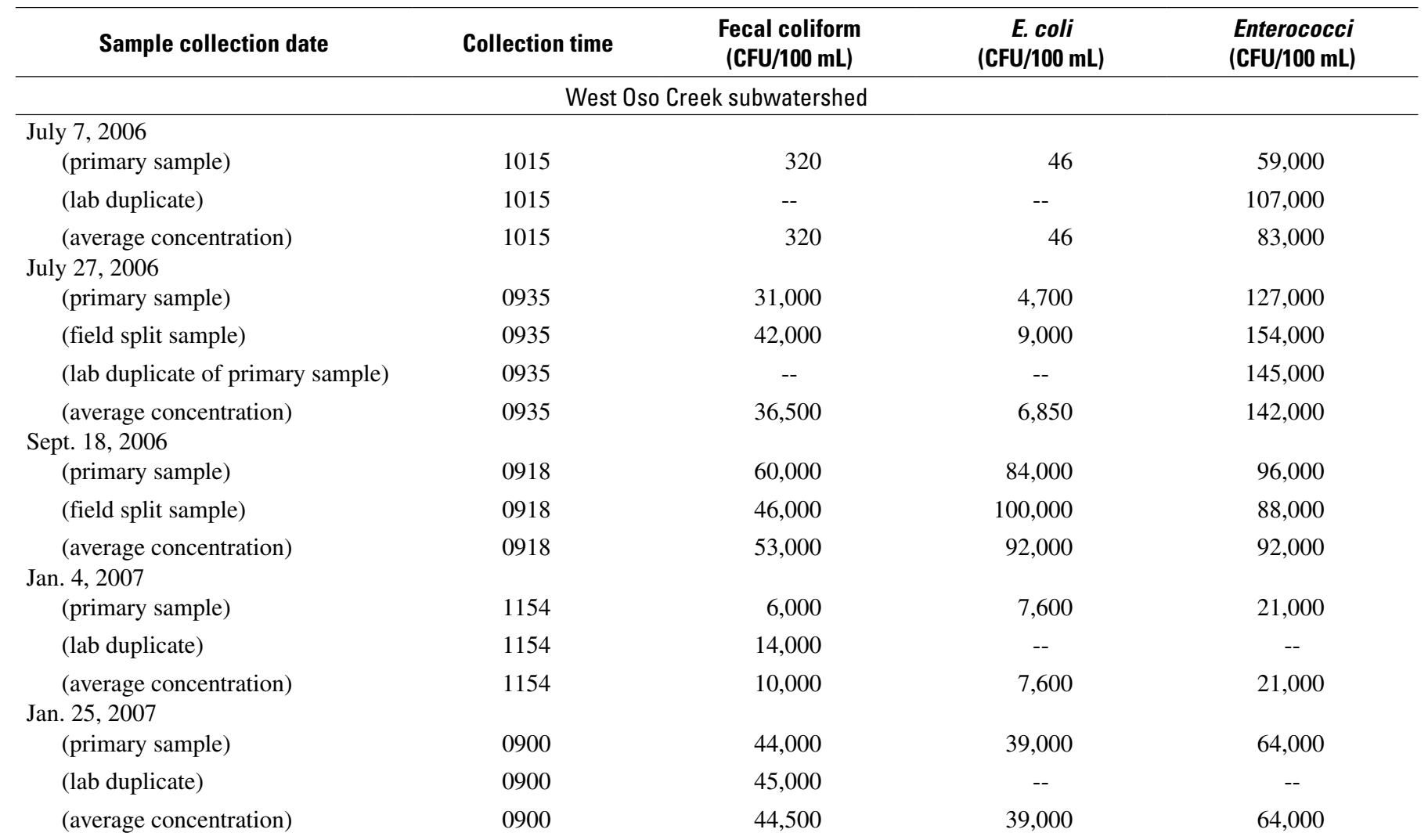


Table 22. Bacteria densities in runoff samples from West 0so Creek (station 08211517) and 0so Creek tributary (station 08211525) subwatersheds, Nueces County, Texas, water years 2006-08-Continued.

\begin{tabular}{|c|c|c|c|c|}
\hline Sample collection date & Collection time & $\begin{array}{l}\text { Fecal coliform } \\
\text { (CFU/100 mL) }\end{array}$ & $\begin{array}{c}\text { E. coli } \\
\text { (CFU/100 mL) }\end{array}$ & $\begin{array}{l}\text { Enterococci } \\
\text { (CFU/100 mL) }\end{array}$ \\
\hline \multicolumn{5}{|c|}{ West Oso Creek subwatershed-Continued } \\
\hline $\begin{array}{l}\text { May } 25,2007 \\
\quad \text { (primary sample) }\end{array}$ & 1512 & 304 & 391 & 5,200 \\
\hline (lab duplicate) & 1512 & 761 & -- & -- \\
\hline (average concentration) & 1512 & 532 & 391 & 5,200 \\
\hline \multicolumn{5}{|l|}{ July 7,2007} \\
\hline (primary sample) & 1150 & -- & 15,600 & 45,000 \\
\hline (field split sample) & 1150 & -- & 5,800 & 83,000 \\
\hline (lab duplicate of primary sample) & 1150 & -- & 7,200 & 49,000 \\
\hline (average concentration) & 1150 & -- & 9,530 & 59,000 \\
\hline \multicolumn{5}{|l|}{ Aug. 30,2007} \\
\hline (primary sample) & 1540 & 82,000 & 12,500 & 145,000 \\
\hline (field split sample) & 1540 & 69,000 & 69,000 & 143,000 \\
\hline (lab duplicate of primary sample) & 1540 & -- & 30,000 & -- \\
\hline (average concentration) & 1540 & 75,500 & 37,200 & 144,000 \\
\hline \multicolumn{5}{|l|}{ July 24, 2008} \\
\hline (primary sample) & 1015 & 10,200 & 1,550 & 127,000 \\
\hline (field split sample) & 1015 & 9,800 & 1,125 & 197,000 \\
\hline (average concentration) & 1015 & 10,000 & 1,338 & 162,000 \\
\hline \multicolumn{5}{|l|}{ Aug. 18, 2008} \\
\hline (primary sample) & 0935 & $<63$ & 250 & 11,600 \\
\hline (field split sample) & 0935 & $<63$ & 125 & 11,500 \\
\hline (average concentration) & 0935 & $<63$ & 188 & 11,600 \\
\hline \multicolumn{5}{|c|}{ Oso Creek tributary subwatershed } \\
\hline \multicolumn{5}{|l|}{ July 7, 2006} \\
\hline (primary sample) & 1110 & 145 & 80 & 4,800 \\
\hline (field split sample) & 1110 & 253 & 77 & 5,200 \\
\hline (lab duplicate) & 1110 & -- & 53 & -- \\
\hline (lab duplicate of primary sample) & 1110 & 83 & -- & -- \\
\hline (average concentration) & 1110 & 160 & 70 & 5,000 \\
\hline \multicolumn{5}{|l|}{ Sept. 15, 2006} \\
\hline (primary sample) & 1000 & 3,600 & 16,000 & 25,000 \\
\hline (field split sample) & 1000 & 8,000 & 21,000 & 28,000 \\
\hline (lab duplicate of primary sample) & 1000 & -- & -- & 25,000 \\
\hline (average concentration) & 1000 & 5,800 & 18,500 & 26,000 \\
\hline \multicolumn{5}{|l|}{ Jan. 4, 2007} \\
\hline (primary sample) & 1217 & 4,300 & 5,300 & 31,000 \\
\hline (field split sample) & 1217 & 2,780 & 3,000 & 39,000 \\
\hline (average concentration) & 1217 & 3,540 & 4,150 & 35,000 \\
\hline \multicolumn{5}{|l|}{ Jan. 25,2007} \\
\hline (primary sample) & 0920 & 14,900 & 4,100 & 22,000 \\
\hline \multicolumn{5}{|l|}{ July 2, 2007} \\
\hline (primary sample) & 1150 & -- & 5,000 & 75,000 \\
\hline July 24, 2008 (primary sample) & 1100 & 1,600 & 933 & 71,000 \\
\hline (field split sample) & 1100 & -- & -- & 83,000 \\
\hline (average concentration) & 1100 & 1,600 & 933 & 77,000 \\
\hline \multicolumn{5}{|l|}{ Aug. 18,2008} \\
\hline (primary sample) & 1015 & $<63$ & 188 & 10,800 \\
\hline (field split sample) & 1015 & $<63$ & 313 & 5,800 \\
\hline (average concentration) & 1015 & $<63$ & 250 & 8,300 \\
\hline
\end{tabular}


Table 23. Summary statistics of bacteria densities in runoff samples from West 0 so Creek (station 08211517) and Oso Creek tributary (station 08211525) subwatersheds, Nueces County, Texas, water years 2006-08; and Texas surface-water-quality standards for bacteria in Oso Bay and Oso Creek, Texas Commission on Environmental Quality segments 2485 and 2485A, respectively.

[CFU/100 mL, colony forming units per 100 milliliters; TSWQS, Texas surface-water-quality standard; <, less than; E. coli, Escherichia coli]

\begin{tabular}{|c|c|c|c|c|c|c|}
\hline Bacteria & $\begin{array}{c}\text { Number of } \\
\text { samples }\end{array}$ & $\begin{array}{c}\text { Mean } \\
\text { (CFU/100 mL) }\end{array}$ & $\begin{array}{c}\text { Median } \\
\text { (CFU/100 mL) }\end{array}$ & $\begin{array}{l}\text { Minimum } \\
\text { (CFU/100 mL) }\end{array}$ & $\begin{array}{l}\text { Maximum } \\
\text { (CFU/100 mL) }\end{array}$ & $\begin{array}{c}\text { TSWOS }^{1} \\
\text { (CFU/100 mL) } \\
\text { for receiving waters } \\
\text { of Oso Bay and } \\
\text { Oso Creek }\end{array}$ \\
\hline \multicolumn{7}{|c|}{ West Oso Creek subwatershed } \\
\hline Fecal coliform & 9 & 25,600 & 10,000 & $<63$ & 75,500 & ${ }^{2} 200 / 400$ \\
\hline E. coli & 10 & 19,400 & 7,220 & 46 & 92,000 & ${ }^{3} 126 / 394$ \\
\hline Enterococci & 10 & 78,400 & 73,500 & 5,200 & 162,000 & ${ }^{4} 35 / 89$ \\
\hline \multicolumn{7}{|c|}{ Oso Creek tributary subwatershed } \\
\hline Fecal coliform & 6 & 4,340 & 2,570 & $<63$ & 14,900 & ${ }^{2} 200 / 400$ \\
\hline E. coli & 7 & 4,720 & 4,100 & 70 & 18,500 & ${ }^{3} 126 / 394$ \\
\hline Enterococci & 7 & 35,500 & 26,000 & 5,000 & 77,000 & ${ }^{4} 35 / 89$ \\
\hline
\end{tabular}

${ }^{1}$ Texas Commission on Environmental Quality (2006).

${ }^{2}$ Geometric mean of fecal coliform should not exceed $200 \mathrm{CFU} / 100 \mathrm{~mL}$; single samples should not exceed $400 \mathrm{CFU} / 100 \mathrm{~mL}$ (freshwater, contact recreation criteria).

${ }^{3}$ Geometric mean of E. coli should not exceed $126 \mathrm{CFU} / 100 \mathrm{~mL}$; single samples should not exceed $394 \mathrm{CFU} / 100 \mathrm{~mL}$ (freshwater, contact recreation criteria).

${ }^{4}$ Geometric mean of Enterococci should not exceed 35 CFU/100 mL; single samples should not exceed $89 \mathrm{CFU} / 100 \mathrm{~mL}$ (saltwater, contact recreation criteria).

\section{Summary}

During water years 2006-08 (October 2005-September 2008), the U.S. Geological Survey (USGS), in cooperation with the Texas State Soil and Water Conservation Board, Coastal Bend Bays and Estuaries Program (CBBEP), and Texas AgriLife Research and Extension Center at Corpus Christi, studied hydrologic conditions and water quality of rainfall and storm runoff of two primarily agricultural subwatersheds of the Oso Creek watershed in Nueces County, Texas. One area, the upper West Oso Creek subwatershed, is about 5,145 acres. The other area, a subwatershed drained by an unnamed tributary to Oso Creek (hereinafter, Oso Creek tributary), is about 5,287 acres.

Rainfall and runoff (streamflow) were continuously monitored at USGS stations at the outlets of the study subwatersheds during the 3-year study. Seventeen rainfall samples were collected and analyzed for nutrients and major inorganic ions. Twenty-four composite runoff samples were collected and analyzed for nutrients, major inorganic ions, and pesticides. Twenty-six discrete suspended-sediment samples were collected and analyzed, and 17 bacteria samples were collected and analyzed for fecal coliform, Escherichia coli (E. coli), and Enterococcus. These rainfall, streamflow, and water-quality data were used to estimate loads of selected constituents entering the study subwatersheds in rainfall and exiting the subwatersheds in runoff. Data on applications of fertilizers to croplands in the study subwatersheds were compiled and compared with quantities of nutrients in rainfall deposition and runoff yields, and data on applications of pesticides were compiled and compared with quantities of pesticides in runoff yields.

For the study period, total rainfall was greater than average, although annual rainfall was less than average in each of water years 2006 and 2008, and monthly rainfall was less than average during 23 of the 36 months. Runoff in the subwatersheds during water years 2006-08 corresponded to rainfall patterns, with periods of runoff interspersed between considerable periods of no runoff. Most of the runoff from the two subwatersheds occurred in response to a few temporally isolated storm periods. More than 60 percent of the runoff from each subwatershed occurred during two wet periods: September 18-October 1, 2006, and July 2-August 8, 2007. During both of these periods, multiple rainfall events and prolonged wetsoil conditions contributed to substantial runoff. The West Oso Creek subwatershed produced more runoff during the study period than the Oso Creek tributary subwatershed, 13.95 in. compared with $9.45 \mathrm{in}$. Runoff response was quicker and peak flows were larger in the West Oso Creek subwatershed than in the Oso Creek tributary subwatershed. 
Most of the nitrogen in rainfall was in the form of dissolved ammonia and dissolved nitrate, which were detected in all samples. Median concentrations of ammonia and nitrate were 0.17 and $0.12 \mathrm{mg} / \mathrm{L}$, respectively. Organic forms of nitrogen were detected in all samples at relatively low concentrations; the median value of total organic nitrogen was 0.08 $\mathrm{mg} / \mathrm{L}$. Nitrite was detected in less than one-half of the samples at low concentrations; the median concentration was less than $0.002 \mathrm{mg} / \mathrm{L}$. Total phosphorus was detected in about one-half of the samples at relatively low concentrations; the median concentration was less than $0.007 \mathrm{mg} / \mathrm{L}$.

Based on rainfall volumes in the study subwatersheds and sample concentrations, daily total nitrogen and total phosphorus deposition were computed for each subwatershed. The average (area-weighted) annual total nitrogen deposition for both subwatersheds over the 3-year study period was 4.47 (lb/acre)/yr, compared with less than 0.07 (lb/acre)/yr for total phosphorus.

Statistical tests (Wilcoxon rank-sum tests) indicate significant differences in median values of event-mean runoff concentrations between the two subwatersheds. Nitrogen concentrations in runoff were greater at the West Oso Creek site than at the Oso Creek tributary site. Major inorganic ion concentrations were greater at the Oso Creek tributary site than at the West Oso Creek site. There was no significant difference in total phosphorus concentrations between the subwatersheds.

Runoff loads and yields were computed for selected nutrients. Total nitrogen runoff yield for the 3-year study period averaged 2.62 (lb/acre)/yr from the West Oso Creek subwatershed and 0.839 (lb/acre)/yr from the Oso Creek tributary subwatershed. Total phosphorus yields from the West Oso Creek and Oso Creek tributary subwatersheds for the 3-year period were 0.644 and 0.419 (lb/acre)/yr, respectively. Runoff yields of nitrogen and phosphorus were relatively small compared to inputs of nitrogen in fertilizer and rainfall deposition. Average annual runoff yield of total nitrogen (subwatersheds combined) represents about 2.5 percent of nitrogen applied as fertilizer and nitrogen entering the subwatersheds through rainfall deposition. Average annual runoff yield of total phosphorus (subwatersheds combined) represents about 4.0 percent of the phosphorus in applied fertilizer and rainfall deposition.

Suspended-sediment yields from the West Oso Creek subwatershed were more than three times those from the Oso Creek tributary subwatershed. The average suspendedsediment yield from the West Oso Creek subwatershed was 522 (lb/acre)/yr. The average suspended-sediment yield from the Oso Creek tributary subwatershed was 139 (lb/acre)/yr.

Thirty-two pesticide compounds ( 24 herbicides and 8 insecticides) were detected in runoff samples collected from the two subwatersheds. At the West Oso Creek subwatershed, 23 pesticides were detected (19 herbicides and 4 insecticides). At the Oso Creek tributary subwatershed, 24 pesticides were detected (18 herbicides and 6 insecticides). Of the 32 pesticides detected during the study, 14 of the pesticides were detected in only one sample (at either one or the other subwatershed site). All of these 14 detections were at low concentrations (near the minimum laboratory reporting level). Two herbicides were detected in all samples: atrazine and atrazine degradation byproduct 2-chloro-4-isopropylamino-6amino-s-triazine (CIAT). Glyphosate and glyphosate byproduct aminomethylphosphonic acid (AMPA) were detected in all samples collected during water years 2006-07. However, these compounds were not included in the analyses of samples collected during water year 2008. Herbicides 2,4-D and pendimethalin were detected in more than 50 percent of the samples.

Runoff yields of the herbicides glyphosate, atrazine, and pendimethalin were greater for the West Oso Creek subwatershed than for the Oso Creek tributary subwatershed. Of all pesticides detected in runoff, the highest runoff yields were for glyphosate: 0.012 (lb/acre)/yr for the West Oso Creek subwatershed and 0.001 (lb/acre)/yr for the Oso Creek tributary subwatershed. Comparison of applications and runoff yields indicates that, for water years 2006-08, about 0.9 percent of glyphosate applied to the West Oso Creek subwatershed croplands was detected in runoff. For the Oso Creek tributary subwatershed, about 0.08 percent of applied glyphosate was detected in runoff.

At both subwatershed outlet sites, most sample concentrations of fecal coliform, E. coli, and Enterococci were greater than Texas surface-water-quality standards for those bacteria established for the receiving waters of Oso Creek and Oso Bay. Because runoff and associated bacteria densities represent relatively brief and infrequent conditions, the resulting effect on Oso Bay and Oso Creek is not known. However, the relatively large bacteria densities (compared to Texas surfacewater-quality standards) indicate that runoff from the study subwatersheds is a potential source of bacteria for Oso Bay and Oso Creek.

Estimates of rainfall nitrogen deposition and runoff loads and yields of nutrients, suspended sediment, and pesticides for 2006-07 from the previous report of the study subwatersheds were revised, based on the collection and analysis of additional data during the 2008 water year. The new data were used to revise the relations used to estimate deposition and loads during unsampled events, resulting in revised estimates of deposition, loads, and yields.

\section{References}

American Public Health Association, 1998, Standard methods for the examination of water and wastewater (20th ed.): Washington, D.C., American Public Health Association, United Book Press, 1,220 p.

Buchanan, T.J., and Somers, W.P., 1969, Discharge measurements at gaging stations: U.S. Geological Survey Techniques of Water-Resources Investigations, book 3, chap. A8, 65 p. 
Childress, C.J.O., Foreman, W.T., Connor, B.F., and Maloney, T.J., 1999, New reporting procedures based on long-term method detection levels and some considerations for interpretations of water-quality data provided by the U.S. Geological Survey National Water Quality Laboratory: U.S. Geological Survey Open-File Report 99-193, 19 p.

Coastal Bend Bays and Estuaries Program, 2008, What is the CCBEP?: accessed March 24, 2008, at http://www.cbbep. org/whatiscbbep/whatis.html.

Davis, B.E., 2005, A guide to the proper selection and use of federally approved sediment and water-quality samplers: U.S. Geological Survey Open-File Report 2005-1087, 26 p.

Federal Interagency Sedimentation Project, 2010, Index of depth-integrating samplers: accessed January 30, 2010, at http://fisp.wes.army.mil/Catalog_Index.htm.

Fishman, M.J., ed., 1993, Methods of analysis by the U.S. Geological Survey National Water Quality LaboratoryDetermination of inorganic and organic constituents in water and fluvial sediments: U.S. Geological Survey OpenFile Report 93-125, 217 p.

Fishman, M.J., and Friedman, L.C., 1989, Methods for determination of inorganic substances in water and fluvial sediments: U.S. Geological Survey Techniques of WaterResources Investigations, book 5, chap. A1, 545 p.

Furlong, E.T., Anderson, B.D., Werner, S.L., Soliven, P.P., Coffey, L.J., and Burkhardt, M.R., 2001, Methods of analysis by the U.S. Geological Survey National Water Quality Laboratory-Determination of pesticides in water by graphitized carbon-based solid-phase extraction and highperformance liquid chromatography/mass spectrometry: U.S. Geological Survey Water-Resources Investigations Report 01-4134, 73 p.

Guy, H.P., 1969, Laboratory theory and methods for sediment analysis: U.S. Geological Survey Techniques of WaterResources Investigations, book 5, chap. C1, 58 p.

Helsel, D.R., and Hirsch, R.M., 2002, Statistical methods in water resources: U.S. Geological Survey Techniques of Water-Resources Investigations, book 4, chap. A3, version 1.1, accessed January 30, 2010, at http://pubs.water.usgs/ twri4a3/.

Huber, W.C., 1993, Contaminant transport in surface water, in Maidment, D.R., ed., Handbook of hydrology: New York, McGraw-Hill, p. 14.1-14.50.

Kennedy, E.J., 1984, Discharge ratings at gaging stations: U.S. Geological Survey Techniques of Water-Resources Investigations, book 3, chap. A10, 59 p.

Komor, S.C., and Hansen, D.S., 2003, Attenuation of runoff and chemical loads in grass filter strips at two cattle feedlots, Minnesota, 1995-98: U.S. Geological Survey WaterResources Investigations Report 03-4036, 15 p.
Larkin, T.J., and Bomar, G.W., 1983, Climatic atlas of Texas: Texas Department of Water Resources Report LP-192, $151 \mathrm{p}$.

Lindley, C.E., Stewart, J.T., and Sandstrom, M.W., 1996, Determination of low concentrations of acetochlor in water by automated solid-phase extraction and gas chromatography with mass selective detection: Journal of AOAC International, v. 79, no. 4, p. 962-966.

Madsen, J.E., Sandstrom, M.W., and Zaugg, S.D., 2003, Methods of analysis by the U.S. Geological Survey National Water Quality Laboratory-A method supplement for the determination of fipronil and degradates in water by gas chromatography/mass spectrometry: U.S. Geological Survey Open-File Report 02-462, 11 p.

Ockerman, D.J., 2008, Hydrologic conditions and quality of rainfall and storm runoff for two agricultural areas of the Oso Creek watershed, Nueces County, Texas, 2005-07: U.S. Geological Survey Scientific Investigations Report 2008-5103, 67 p.

Ockerman, D.J., and Livingston, C.W., 1999, Nitrogen concentrations and deposition in rainfall at two sites in the Coastal Bend area, South Texas, 1996-98: U.S. Geological Survey Fact Sheet 146-99, 6 p.

Patton, C.J., and Truitt, E.P., 2000, Methods of analysis by the U.S. Geological Survey National Water Quality Laboratory-Determination of ammonium plus organic nitrogen by a Kjeldahl digestion method and an automated photometric finish that includes digest cleanup by gas diffusion: U.S. Geological Survey Open-File Report 00-170, $31 \mathrm{p}$.

Quenzer, A.M., Maidment, D.R., Hellweger, F.L., Eid, N.J., Ward, G.H., and Armstrong, N.E., 1998, Total loads and water quality in the Corpus Christi Bay System: Texas Natural Resource Conservation Commission, Corpus Christi Bay National Estuary Program CCBNEP-27, 226 p.

Sandstrom, M.W., Stroppel, M.E., Foreman, W.T., and Schroeder, M.P., 2001, Methods of analysis by the U.S. Geological Survey National Water Quality LaboratoryDetermination of moderate-use pesticides and selected degradates in water by $\mathrm{C}$ - 18 solid-phase extraction and gas chromatography/mass spectrometry: U.S. Geological Survey Water-Resources Investigations Report 01-4098, $70 \mathrm{p}$.

SonTek, 2010, Argonaut-SW (shallow water): accessed July 6, 2010, at http://www.sontek.com/argonautsw.php.

Texas Commission on Environmental Quality, 2003, Surface water quality monitoring procedures, volume 1-Physical and chemical monitoring methods for water, sediment, and tissue: Austin, Texas Commission on Environmental Quality, RG-415, 198 p. 
Texas Commission on Environmental Quality, 2006, 2000 Texas surface water quality standards: accessed October, 15, 2007, at http://www.tceq.state.tx.us/permitting/water quality/wq_assessment/standards/WQ_standards_2000. html.

Texas Commission on Environmental Quality, 2007, Oso Bay and Oso Creek-A TMDL project for bacteria: accessed September 15, 2007, at http://www.tceq.state.tx.us/ implementation/water/tmdl/67-osobaybacteria.html.

Texas Commission on Environmental Quality, 2008, 2008 Texas water quality inventory and 303(d) list: accessed March 25, 2008, at http://www.tceq.state.tx.us/compliance/ monitoring/water/quality/data/08twqi/twqi08.html.

U.S. Department of Agriculture, Agricultural Research Service, 2006, Revised universal soil loss equation (RUSLE): accessed November 18, 2007, at $h t t p: / / w w w$ ars. usda.gov/Research/docs.htm?docid=5971.

U.S. Department of Agriculture, Soil Conservation Service, 1965, Soil survey Nueces County, Texas: Series 1960, no. 26,65 p., 79 map sheets.

U.S. Department of Commerce, National Climatic Data Center, 2006, Find a station: accessed September 13, 2007, at http://www.ncdc.noaa.gov/oa/ncdc.html.

U. S. Environmental Protection Agency, 1993, Method 365.1, Determination of phosphorus by semi-automated colorimetry revision 2.0-Methods for the determination of inorganic substances in environmental samples: Cincinnati, Ohio, U.S. Environmental Protection Agency, Office of Research and Development, Environmental Monitoring Systems Laboratory, $17 \mathrm{p}$.

U.S. Environmental Protection Agency, 2000, Improved enumeration methods for the recreational water quality indicators-Enterococci and Escherichia coli: Washington D.C., U.S. Environmental Protection Agency, Office of Science and Technology, $49 \mathrm{p}$.
U.S. Environmental Protection Agency, 2008, National estuary program - Coastal Bend bays and estuaries: accessed March 24, 2008, at http://www.epa.gov/owow/estuaries/programs/ ccb.htm.

U.S. Geological Survey, 2006, Collection of water samples: U.S. Geological Survey Techniques of Water-Resources Investigations, book 9, chap. A4, accessed August 24, 2007, at http://pubs.water.usgs.gov/twri9A4/.

U.S. Geological Survey, 2007, Office of Water Quality, Branch of Quality Systems: accessed April 7, 2008, at http://bqs. usgs.gov.

U.S. Geological Survey, 2008, National Water Information System (NWISWeb) data available on the World Wide Web: accessed September 2007-January 2008 at http://waterdata. usgs.gov/nwis/.

U.S. Geological Survey, 2010, Branch of Quality SystemsOrganic Blind Sample Project, statistical data tables: accessed July 6, 2010, at http://bqs.usgs.gov/OBSP/ pickAyear4data.html.

Wanielista, M.P., 1990, Hydrology and water quantity control: New York, Wiley, 565 p.

Wilde, F.D., Radtke, D.B., Gibs, Jacob, and Iwatsubo, R.T., eds, 2004 [with updates through 2009], Processing of water samples (version 2.2): U.S. Geological Survey Techniques of Water-Resources Investigations, book 9, chap. A5, accessed January 30, 2010, at http://pubs.water.usgs.gov/ twri9A5/.

Zaugg, S.D., Sandstrom, M.W., Smith, S.G., and Fehlberg, K.M., 1995, Methods of analysis by the U.S. Geological Survey National Water Quality Laboratory-Determination of pesticides in water by $\mathrm{C}-18$ solid-phase extraction and capillary-column gas chromatography/mass spectrometry with selected-ion monitoring: U.S. Geological Survey Open-File Report 95-181, 60 p. 
Blank Page 
Appendixes 1-3 
Blank Page 
Appendix 1. Quality control and assurance data for rainfall samples collected at Texas AgriLife Research at Corpus Christi (station 08211511); and for runoff samples collected at West Oso Creek (station 08211517) and Oso Creek tributary (station 08211525), Nueces County, Texas, water years 2006-08.

[unfltrd, unfiltered; $\mu \mathrm{S} / \mathrm{cm}$, microsiemens per centimeter at 25 degrees Celsius; fltrd, filtered; $\mathrm{mg} / \mathrm{L}$, milligrams per liter; E, estimated, <, less than; --, not analyzed; N, nitrogen; P, phosphorus; $\mu \mathrm{g} / \mathrm{L}$, micrograms per liter; CIAT, 2-chloro-4-isopropylamino-6-amino-s-triazine; CEAT, 2-chloro-6-ethylamino-4-aminos-triazine; OIET, 2-hydroxy-4-isopropylamino-6-ethylamino-s-triazine; DCPA, dimethyl tetrachloroterephthalate; MCPA, 4-chloro-2-methylphenoxy acetic acid; MCPB, 4-(2-methyl-4-chlorophenoxy)butyric acid]

\begin{tabular}{|c|c|c|c|c|c|c|c|c|}
\hline Date & Sample type & $\begin{array}{c}\text { pH, water, } \\
\text { unfltrd, lab } \\
\text { (standard units) }\end{array}$ & $\begin{array}{c}\text { Specific } \\
\text { conductance, } \\
\text { unfltrd, lab } \\
(\mu \mathrm{S} / \mathrm{cm})\end{array}$ & $\begin{array}{l}\text { Calcium, } \\
\text { water, fltrd } \\
\text { (mg/L) }\end{array}$ & $\begin{array}{c}\text { Magnesium, } \\
\text { water, } \\
\text { fltrd } \\
\text { (mg/L) }\end{array}$ & $\begin{array}{l}\text { Potassium, } \\
\text { water, } \\
\text { fltrd } \\
\text { (mg/L) }\end{array}$ & $\begin{array}{c}\text { Sodium, } \\
\text { water, } \\
\text { fltrd } \\
\text { (mg/L) }\end{array}$ & $\begin{array}{c}\text { Chloride, } \\
\text { water, } \\
\text { fltrd } \\
\text { (mg/L) }\end{array}$ \\
\hline \multicolumn{9}{|c|}{ Station 08211511-Texas AgriLife Research at Corpus Christi, Tex. } \\
\hline Mar. 28, 2006 & Blank & 8.5 & 3 & 0.11 & E0.005 & E0.005 & 0.26 & $<0.01$ \\
\hline Oct. 25,2007 & Blank & 6.1 & 5 & $<.04$ & $<.02$ & .006 & $<.12$ & $<.01$ \\
\hline
\end{tabular}

Station 08211517—West Oso Creek at Merrett Road near Corpus Christi, Tex.

\begin{tabular}{|c|c|c|c|c|c|c|c|c|}
\hline Nov. 20, 2006 & Blank & -- & -- & -- & -- & -- & -- & -- \\
\hline Oct. 25,2007 & Blank & 5.8 & 5 & $<.04$ & $<.02$ & .007 & $<.12$ & $<.01$ \\
\hline \multicolumn{9}{|c|}{ Station 08211525-Unnamed Oso Creek tributary at Farm Road 2444 near Corpus Christi, Tex. } \\
\hline Mar. 28, 2006 & Blank & 9.5 & 14 & $<.04$ & .02 & .03 & $<.12$ & $<.01$ \\
\hline
\end{tabular}

\begin{tabular}{|c|c|c|c|c|c|c|c|c|}
\hline Date & Sample type & $\begin{array}{c}\text { Fluoride, } \\
\text { water, } \\
\text { fltrd } \\
\text { (mg/L) }\end{array}$ & $\begin{array}{c}\text { Silica, } \\
\text { water, } \\
\text { fltrd } \\
\text { (mg/L) }\end{array}$ & $\begin{array}{c}\text { Sulfate, } \\
\text { water, } \\
\text { fltrd } \\
\text { (mg/L) }\end{array}$ & $\begin{array}{c}\text { Ammonia } \\
+ \text { organic-N, } \\
\text { water, fltrd } \\
\text { (mg/L as } \mathrm{N})\end{array}$ & $\begin{array}{c}\text { Ammonia } \\
\text { + organic-N, } \\
\text { water, unfltrd } \\
\text { (mg/L as } \mathrm{N})\end{array}$ & $\begin{array}{l}\text { Ammonia, } \\
\text { water, } \\
\text { fltrd } \\
\text { (mg/L as } \mathrm{N} \text { ) }\end{array}$ & $\begin{array}{c}\text { Nitrite } \\
+ \text { nitrate, } \\
\text { water, fltrd } \\
(\mathrm{mg} / \mathrm{L} \text { as } \mathrm{N})\end{array}$ \\
\hline \multicolumn{9}{|c|}{ Station 08211511-Texas AgriLife Research at Corpus Christi, Tex. } \\
\hline Mar. 28, 2006 & Blank & 0.03 & -- & $<0.01$ & $<0.10$ & $<0.10$ & $<0.01$ & $<0.016$ \\
\hline Nov. 20, 2006 & Blank & -- & -- & -- & -- & -- & -- & -- \\
\hline Oct. 25,2007 & Blank & $<.01$ & $<.02$ & $<.01$ & -- & -- & $<.02$ & $<.016$ \\
\hline
\end{tabular}

Station 08211525-Unnamed Oso Creek tributary at Farm Road 2444 near Corpus Christi, Tex.

\begin{tabular}{llllllll}
\hline Mar. 28, 2006 & Blank & .03 & .03 & $<.01$ & -- & $<.01<.016$
\end{tabular}

\begin{tabular}{|c|c|c|c|c|c|c|c|c|}
\hline Date & Sample type & $\begin{array}{c}\text { Nitrite, } \\
\text { water, } \\
\text { fltrd } \\
\text { (mg/L as N) }\end{array}$ & $\begin{array}{c}\text { Organic } \\
\text { nitrogen, } \\
\text { water, } \\
\text { fltrd } \\
\text { (mg/L as N) }\end{array}$ & $\begin{array}{c}\text { Organic } \\
\text { nitrogen, } \\
\text { water, } \\
\text { unfltrd } \\
\text { (mg/L as } \mathrm{N} \text { ) }\end{array}$ & $\begin{array}{c}\text { Total } \\
\text { nitrogen, } \\
\text { water, } \\
\text { fltrd } \\
\text { (mg/L as N) }\end{array}$ & $\begin{array}{c}\text { Total } \\
\text { nitrogen, } \\
\text { water, } \\
\text { unfltrd } \\
\text { (mg/L as } \mathrm{N} \text { ) }\end{array}$ & $\begin{array}{c}\text { Ortho- } \\
\text { phosphate, } \\
\text { water, } \\
\text { fltrd } \\
\text { (mg/L as } \mathrm{P} \text { ) }\end{array}$ & $\begin{array}{c}\text { Phosphorus, } \\
\text { water, } \\
\text { unfltrd } \\
\text { (mg/L as } \mathrm{P} \text { ) }\end{array}$ \\
\hline \multicolumn{9}{|c|}{ Station 08211511 -Texas AgriLife Research at Corpus Christi, Tex. } \\
\hline Mar. 28, 2006 & Blank & $<0.002$ & -- & -- & -- & -- & $<0.006$ & $<0.004$ \\
\hline \multicolumn{9}{|c|}{ Station 08211517-West Oso Creek at Merrett Road near Corpus Christi, Tex. } \\
\hline Nov. 20, 2006 & Blank & -- & -- & -- & -- & -- & -- & -- \\
\hline Oct. 25,2007 & Blank & $<.002$ & -- & -- & -- & -- & $<.006$ & -- \\
\hline
\end{tabular}

Station 08211525-Unnamed Oso Creek tributary at Farm Road 2444 near Corpus Christi, Tex.

Mar. 28, 2006 Blank

E.001

$<.006$ 
Appendix 1. Quality control and assurance data for rainfall samples collected at Texas AgriLife Research at Corpus Christi (station 08211511); and for runoff samples collected at West Oso Creek (station 08211517) and Oso Creek tributary (station 08211525), Nueces County, Texas, water years 2006-08-Continued.

\begin{tabular}{|c|c|c|c|c|c|c|c|c|}
\hline Date & Sample type & $\begin{array}{c}\text { 1-Naphthol, } \\
\text { water, } \\
\text { fltrd } \\
\text { ( } \mathrm{gg} / \mathrm{L})\end{array}$ & $\begin{array}{c}\text { 2,4-D } \\
\text { methylester, } \\
\text { water, fltrd } \\
\text { ( } \mathrm{gg} / \mathrm{L})\end{array}$ & $\begin{array}{c}2,4-D, \\
\text { water, } \\
\text { fltrd } \\
(\mu \mathrm{g} / \mathrm{L})\end{array}$ & $\begin{array}{c}\text { 2,4-DB, } \\
\text { water, } \\
\text { fltrd } \\
(\mu \mathrm{g} / \mathrm{L})\end{array}$ & $\begin{array}{c}\text { 2,6-Diethyl- } \\
\text { aniline, } \\
\text { water, fltrd } \\
\text { ( } \mathrm{gg} / \mathrm{L})\end{array}$ & $\begin{array}{l}\text { 2-Chloro- } \\
\text { 2,6-diethyl } \\
\text { acetanilide, } \\
\text { water, fltrd } \\
\text { ( } \mathrm{gg} / \mathrm{L})\end{array}$ & $\begin{array}{c}\text { CIAT, } \\
\text { water, } \\
\text { fltrd } \\
(\mu \mathrm{g} / \mathrm{L})\end{array}$ \\
\hline \multicolumn{9}{|c|}{ Station 08211511-Texas AgriLife Research at Corpus Christi, Tex. } \\
\hline Mar. 28, 2006 & -- & -- & -- & -- & -- & -- & -- & -- \\
\hline \multicolumn{9}{|c|}{ Station 08211517-West Oso Creek at Merrett Road near Corpus Christi, Tex. } \\
\hline Nov. 20, 2006 & Blank & $<0.09$ & $<0.19$ & $<0.04$ & $<0.02$ & $<0.006$ & $<0.006$ & $<0.014$ \\
\hline Oct. 25,2007 & -- & -- & -- & -- & -- & -- & -- & -- \\
\hline Date & Sample type & $\begin{array}{c}\text { CEAT, } \\
\text { water, } \\
\text { fltrd } \\
(\mu \mathrm{g} / \mathrm{L})\end{array}$ & $\begin{array}{l}\text { 2-Ethyl-6- } \\
\text { methyl- } \\
\text { aniline, } \\
\text { water, fltrd } \\
\text { ( } \mu \mathrm{g} / \mathrm{L})\end{array}$ & $\begin{array}{c}\text { OIET, } \\
\text { water, } \\
\text { fltrd } \\
\text { ( } \mu \mathrm{g} / \mathrm{L})\end{array}$ & $\begin{array}{l}\text { 3,4-Dichloro- } \\
\text { aniline, } \\
\text { water, fltrd } \\
(\mu \mathrm{g} / \mathrm{L})\end{array}$ & $\begin{array}{c}\text { 3-Hydroxy } \\
\text { carbofuran, } \\
\text { water, fltrd } \\
\text { ( } \mathrm{gg} / \mathrm{L})\end{array}$ & $\begin{array}{l}\text { 4-Chloro- } \\
\text { 2-methyl } \\
\text { phenol, } \\
\text { water, fltrd } \\
\text { ( } \mu \mathrm{g} / \mathrm{L})\end{array}$ & $\begin{array}{l}\text { Acetochlor, } \\
\text { water, } \\
\text { fltrd } \\
\text { ( } \mathrm{gg} / \mathrm{L})\end{array}$ \\
\hline \multicolumn{9}{|c|}{ Station 08211511-Texas AgriLife Research at Corpus Christi, Tex. } \\
\hline Mar. 28, 2006 & -- & -- & -- & -- & -- & -- & -- & -- \\
\hline Oct. 25,2007 & -- & -- & -- & -- & -- & -- & -- & -- \\
\hline Date & Sample type & $\begin{array}{l}\text { Acifluorfen, } \\
\text { water, } \\
\text { fltrd } \\
\text { ( } \mu \mathrm{g} / \mathrm{L})\end{array}$ & $\begin{array}{c}\text { Alachlor, } \\
\text { water, } \\
\text { fltrd } \\
(\mu \mathrm{g} / \mathrm{L})\end{array}$ & $\begin{array}{c}\text { Aldicarb } \\
\text { sulfone, } \\
\text { water, fltrd } \\
(\mu \mathrm{g} / \mathrm{L})\end{array}$ & $\begin{array}{c}\text { Aldicarb } \\
\text { sulfoxide, } \\
\text { water, fltrd } \\
\text { ( } \mathrm{gg} / \mathrm{L})\end{array}$ & $\begin{array}{c}\text { Aldicarb, } \\
\text { water, } \\
\text { fltrd } \\
(\mu \mathrm{g} / \mathrm{L})\end{array}$ & $\begin{array}{c}\text { Atrazine, } \\
\text { water, } \\
\text { fltrd } \\
(\mu \mathrm{g} / \mathrm{L})\end{array}$ & $\begin{array}{c}\text { Azinphos- } \\
\text { methyl oxon, } \\
\text { water, fltrd } \\
(\mu \mathrm{g} / \mathrm{L})\end{array}$ \\
\hline \multicolumn{9}{|c|}{ Station 08211511-Texas AgriLife Research at Corpus Christi, Tex. } \\
\hline Mar. 28, 2006 & -- & -- & -- & -- & -- & -- & -- & -- \\
\hline Oct. 25,2007 & -- & -- & -- & -- & -- & -- & -- & -- \\
\hline \multicolumn{9}{|c|}{ Station 08211517-West Oso Creek at Merrett Road near Corpus Christi, Tex. } \\
\hline Nov. 20, 2006 & Blank & $<0.06$ & $<0.005$ & $<0.08$ & $<0.04$ & $<0.04$ & $<0.007$ & $<0.04$ \\
\hline Oct. 25, 2007 & -- & -- & -- & -- & -- & -- & -- & -- \\
\hline
\end{tabular}

Station 08211525-Unnamed Oso Creek tributary at Farm Road 2444 near Corpus Christi, Tex.

Mar. 28, 2006 
Appendix 1. Quality control and assurance data for rainfall samples collected at Texas AgriLife Research at Corpus Christi (station 08211511); and for runoff samples collected at West Oso Creek (station 08211517) and Oso Creek tributary (station 08211525), Nueces County, Texas, water years 2006-08-Continued.

\begin{tabular}{|c|c|c|c|c|c|c|c|c|}
\hline Date & Sample type & $\begin{array}{l}\text { Azinphos- } \\
\text { methyl, } \\
\text { water, fltrd } \\
(\mu \mathrm{g} / \mathrm{L})\end{array}$ & $\begin{array}{c}\text { Bendiocarb, } \\
\text { water, } \\
\text { fltrd } \\
\text { ( } \mathrm{gg} / \mathrm{L})\end{array}$ & $\begin{array}{c}\text { Benfluralin, } \\
\text { water, } \\
\text { fltrd } \\
\text { ( } \mu \mathrm{g} / \mathrm{L})\end{array}$ & $\begin{array}{c}\text { Benomyl, } \\
\text { water, } \\
\text { fltrd } \\
(\mu \mathrm{g} / \mathrm{L})\end{array}$ & $\begin{array}{c}\text { Bensul- } \\
\text { furon } \\
\text { methyl, } \\
\text { water, fltrd } \\
(\mu \mathrm{g} / \mathrm{L})\end{array}$ & $\begin{array}{c}\text { Bentazon, } \\
\text { water, } \\
\text { fltrd } \\
\text { ( } \mu \mathrm{g} / \mathrm{L})\end{array}$ & $\begin{array}{c}\text { Bromacil, } \\
\text { water, } \\
\text { fltrd } \\
\text { ( } \mu \mathrm{g} / \mathrm{L})\end{array}$ \\
\hline \multicolumn{9}{|c|}{ Station 08211511-Texas AgriLife Research at Corpus Christi, Tex. } \\
\hline Mar. 28, 2006 & -- & -- & -- & -- & -- & -- & -- & -- \\
\hline \multicolumn{9}{|c|}{ Station 08211517-West Oso Creek at Merrett Road near Corpus Christi, Tex. } \\
\hline Nov. 20, 2006 & Blank & $<0.08$ & $<0.04$ & $<0.01$ & $<0.02$ & $<0.06$ & $<0.02$ & $<0.04$ \\
\hline Oct. 25, 2007 & -- & -- & -- & -- & -- & -- & -- & -- \\
\hline
\end{tabular}

Station 08211525 - Unnamed Oso Creek tributary at Farm Road 2444 near Corpus Christi, Tex.

Mar. 28, 2006

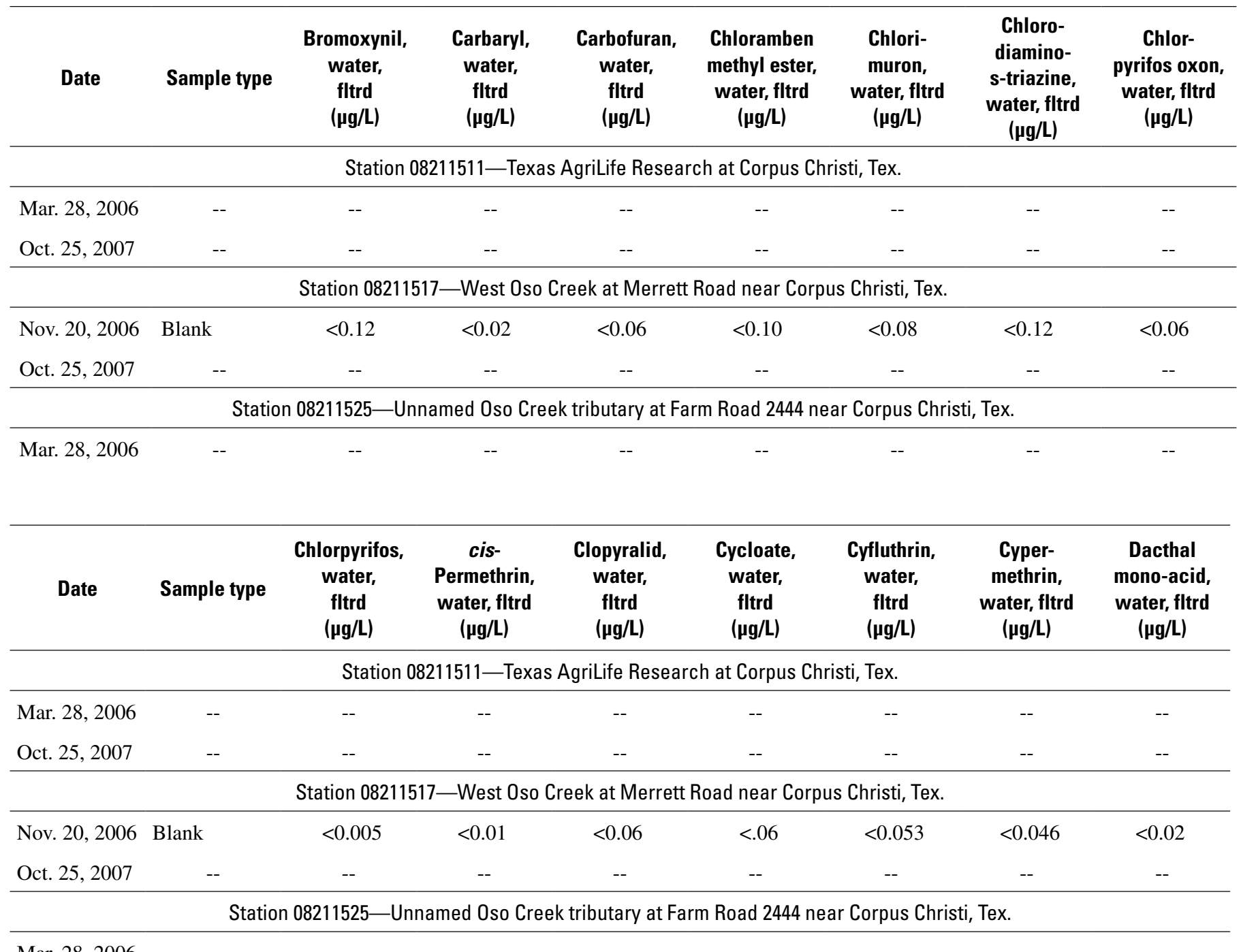

Mar. 28, 2006 
Appendix 1. Quality control and assurance data for rainfall samples collected at Texas AgriLife Research at Corpus Christi (station 08211511); and for runoff samples collected at West Oso Creek (station 08211517) and Oso Creek tributary (station 08211525), Nueces County, Texas, water years 2006-08-Continued.

\begin{tabular}{|c|c|c|c|c|c|c|c|c|}
\hline Date & Sample type & $\begin{array}{c}\text { DCPA, } \\
\text { water, } \\
\text { fltrd } \\
(\mu \mathrm{g} / \mathrm{L})\end{array}$ & $\begin{array}{c}\text { Desulfinyl- } \\
\text { fipronil, } \\
\text { water, fltrd } \\
(\mu \mathrm{g} / \mathrm{L})\end{array}$ & $\begin{array}{c}\text { Diazinon, } \\
\text { water, } \\
\text { fltrd } \\
(\mu \mathrm{g} / \mathrm{L})\end{array}$ & $\begin{array}{c}\text { Dicamba, } \\
\text { water, } \\
\text { fltrd } \\
(\mu \mathrm{g} / \mathrm{L})\end{array}$ & $\begin{array}{c}\text { Dichlorprop, } \\
\text { water, } \\
\text { fltrd } \\
(\mu \mathrm{g} / \mathrm{L})\end{array}$ & $\begin{array}{c}\text { Dicrotophos, } \\
\text { water, } \\
\text { fltrd } \\
(\mu \mathrm{g} / \mathrm{L})\end{array}$ & $\begin{array}{c}\text { Dieldrin, } \\
\text { water, } \\
\text { fltrd } \\
(\mu \mathrm{g} / \mathrm{L})\end{array}$ \\
\hline \multicolumn{9}{|c|}{ Station 08211511-Texas AgriLife Research at Corpus Christi, Tex. } \\
\hline Mar. 28, 2006 & -- & -- & -- & -- & -- & -- & -- & -- \\
\hline Oct. 25,2007 & -- & -- & -- & -- & -- & -- & -- & -- \\
\hline \multicolumn{9}{|c|}{ Station 08211517-West Oso Creek at Merrett Road near Corpus Christi, Tex. } \\
\hline Nov. 11, 2006 & Blank & $<0.003$ & $<0.012$ & $<0.005$ & $<0.08$ & $<0.04$ & $<0.08$ & $<0.009$ \\
\hline Oct. 25,2007 & -- & -- & -- & -- & -- & -- & -- & -- \\
\hline \multicolumn{9}{|c|}{ Station 08211525—Unnamed Oso Creek tributary at Farm Road 2444 near Corpus Christi, Tex. } \\
\hline Mar. 28, 2006 & -- & -- & -- & -- & -- & -- & -- & -- \\
\hline Date & Sample type & $\begin{array}{c}\text { Dimethoate, } \\
\text { water, } \\
\text { fltrd } \\
(\mu \mathrm{g} / \mathrm{L})\end{array}$ & $\begin{array}{c}\text { Dinoseb, } \\
\text { water, } \\
\text { fltrd } \\
(\mu \mathrm{g} / \mathrm{L})\end{array}$ & $\begin{array}{c}\text { Diphenamid, } \\
\text { water, } \\
\text { fltrd } \\
(\mu \mathrm{g} / \mathrm{L})\end{array}$ & $\begin{array}{c}\text { Diuron, } \\
\text { water, } \\
\text { fltrd } \\
(\mu \mathrm{g} / \mathrm{L})\end{array}$ & $\begin{array}{c}\text { Ethion } \\
\text { monoxon, } \\
\text { water, fltrd } \\
(\mu \mathrm{g} / \mathrm{L})\end{array}$ & $\begin{array}{c}\text { Ethion, } \\
\text { water, } \\
\text { fltrd } \\
(\mu \mathrm{g} / \mathrm{L})\end{array}$ & $\begin{array}{c}\text { Fenamiphos } \\
\text { sulfone, } \\
\text { water, fltrd } \\
(\mu \mathrm{g} / \mathrm{L})\end{array}$ \\
\hline \multicolumn{9}{|c|}{ Station 08211511-Texas AgriLife Research at Corpus Christi, Tex. } \\
\hline Mar. 28, 2006 & -- & -- & -- & -- & -- & -- & -- & -- \\
\hline Oct. 25,2007 & -- & -- & -- & -- & -- & -- & -- & -- \\
\hline \multicolumn{9}{|c|}{ Station 08211517—West Oso Creek at Merrett Road near Corpus Christi, Tex. } \\
\hline Nov. 11, 2006 & Blank & $<0.006$ & $<0.04$ & $<0.04$ & $<0.04$ & $<0.021$ & $<0.016$ & $<0.053$ \\
\hline Oct. 25, 2007 & -- & -- & -- & -- & -- & -- & -- & -- \\
\hline \multicolumn{9}{|c|}{ Station 08211525-Unnamed 0so Creek tributary at Farm Road 2444 near Corpus Christi, Tex. } \\
\hline Mar. 28, 2006 & -- & -- & -- & -- & -- & -- & -- & -- \\
\hline Date & Sample type & $\begin{array}{l}\text { Fenamiphos } \\
\text { sulfoxide, } \\
\text { water, fltrd } \\
(\mu \mathrm{g} / \mathrm{L})\end{array}$ & $\begin{array}{c}\text { Fenamiphos, } \\
\text { water, } \\
\text { fltrd } \\
(\mu \mathrm{g} / \mathrm{L})\end{array}$ & $\begin{array}{c}\text { Fenuron, } \\
\text { water, } \\
\text { fltrd } \\
(\mu g / L)\end{array}$ & $\begin{array}{c}\text { Desulfinyl- } \\
\text { fipronil } \\
\text { amide, } \\
\text { water, fltrd } \\
(\mu \mathrm{g} / \mathrm{L})\end{array}$ & $\begin{array}{c}\text { Fipronil } \\
\text { sulfide, } \\
\text { water, fltrd } \\
(\mu \mathrm{g} / \mathrm{L})\end{array}$ & $\begin{array}{c}\text { Fipronil } \\
\text { sulfone, } \\
\text { water, fltrd } \\
(\mu \mathrm{g} / \mathrm{L})\end{array}$ & $\begin{array}{c}\text { Fipronil, } \\
\text { water, } \\
\text { fltrd } \\
(\mu \mathrm{g} / \mathrm{L})\end{array}$ \\
\hline \multicolumn{9}{|c|}{ Station 08211511-Texas AgriLife Research at Corpus Christi, Tex. } \\
\hline Mar. 28, 2006 & -- & -- & -- & -- & -- & -- & -- & -- \\
\hline Oct. 25,2007 & -- & -- & -- & -- & -- & -- & -- & -- \\
\hline \multicolumn{9}{|c|}{ Station 08211517-West Oso Creek at Merrett Road near Corpus Christi, Tex. } \\
\hline Nov. 11, 2006 & Blank & $<0.04$ & $<0.03$ & $<0.04$ & $<0.029$ & $<0.013$ & $<0.024$ & $<0.016$ \\
\hline Oct. 25, 2007 & -- & -- & -- & -- & -- & -- & -- & -- \\
\hline
\end{tabular}

Mar. 28, 2006 
Appendix 1. Quality control and assurance data for rainfall samples collected at Texas AgriLife Research at Corpus Christi (station 08211511); and for runoff samples collected at West Oso Creek (station 08211517) and Oso Creek tributary (station 08211525), Nueces County, Texas, water years 2006-08-Continued.

\begin{tabular}{|c|c|c|c|c|c|c|c|c|}
\hline Date & Sample type & $\begin{array}{c}\text { Flumetsulam, } \\
\text { water, } \\
\text { fltrd } \\
(\mu \mathrm{g} / \mathrm{L})\end{array}$ & $\begin{array}{c}\text { Fluo- } \\
\text { meturon, } \\
\text { water, fltrd } \\
(\mu \mathrm{g} / \mathrm{L})\end{array}$ & $\begin{array}{c}\text { Fonofos, } \\
\text { water, } \\
\text { fltrd } \\
(\mu \mathrm{g} / \mathrm{L})\end{array}$ & $\begin{array}{c}\text { Glufosinate, } \\
\text { water, } \\
\text { fltrd } \\
(\mu \mathrm{g} / \mathrm{L})\end{array}$ & $\begin{array}{c}\text { Glyphosate, } \\
\text { water, } \\
\text { fltrd } \\
(\mu \mathrm{g} / \mathrm{L})\end{array}$ & $\begin{array}{c}\text { Hexazinone, } \\
\text { water, } \\
\text { fltrd } \\
(\mu \mathrm{g} / \mathrm{L})\end{array}$ & $\begin{array}{c}\text { Imazaquin, } \\
\text { water, } \\
\text { fltrd } \\
(\mu \mathrm{g} / \mathrm{L})\end{array}$ \\
\hline
\end{tabular}

Station 08211511-Texas AgriLife Research at Corpus Christi, Tex.

\begin{tabular}{lllllll}
\hline Mar. 28, 2006 & -- & -- & -- & -- & -- & -- \\
Oct. 25, 2007 & -- & -- & -- & -- & -- & -- \\
\hline
\end{tabular}

Station 08211517—West Oso Creek at Merrett Road near Corpus Christi, Tex.

\begin{tabular}{llllllll}
\hline Nov. 11, 2006 Blank & $<0.06$ & $<0.04$ & $<0.006$ & $<0.14$ & $<0.15$ & $<0.026<4$
\end{tabular}

Oct. 25,2007

Station 08211525—Unnamed Oso Creek tributary at Farm Road 2444 near Corpus Christi, Tex.

Mar. 28, 2006

--

\begin{tabular}{|c|c|c|c|c|c|c|c|c|}
\hline Date & Sample type & $\begin{array}{l}\text { Imazethapyr, } \\
\text { water, } \\
\text { fltrd } \\
(\mu \mathrm{g} / \mathrm{L})\end{array}$ & $\begin{array}{l}\text { Imidacloprid, } \\
\text { water, fltrd } \\
(\mu \mathrm{g} / \mathrm{L})\end{array}$ & $\begin{array}{l}\text { Iprodione, } \\
\text { water, } \\
\text { fltrd } \\
(\mu \mathrm{g} / \mathrm{L})\end{array}$ & $\begin{array}{c}\text { Isofenphos, } \\
\text { water, } \\
\text { fltrd } \\
(\mu \mathrm{g} / \mathrm{L})\end{array}$ & $\begin{array}{c}\text { Linuron, } \\
\text { water, } \\
\text { fltrd } \\
(\mu \mathrm{g} / \mathrm{L})\end{array}$ & $\begin{array}{c}\text { Malaoxon, } \\
\text { water, } \\
\text { fltrd } \\
(\mu \mathrm{g} / \mathrm{L})\end{array}$ & $\begin{array}{c}\text { Malathion, } \\
\text { water, } \\
\text { fltrd } \\
(\mu \mathrm{g} / \mathrm{L})\end{array}$ \\
\hline
\end{tabular}

Station 08211511 - Texas AgriLife Research at Corpus Christi, Tex.

Mar. 28, 2006

Oct. 25,2007

Station 08211517-West Oso Creek at Merrett Road near Corpus Christi, Tex.
Nov. 11, 2006 Blank
$<0.04$
$<0.06$
$<0.026$
$<0.011$
$<0.04$
$<0.039$
$<0.016$

Oct. 25,2007

Station 08211525-Unnamed Oso Creek tributary at Farm Road 2444 near Corpus Christi, Tex.

Mar. 28, 2006

\begin{tabular}{|c|c|c|c|c|c|c|c|c|}
\hline Date & Sample type & $\begin{array}{c}\text { MCPA, } \\
\text { water, } \\
\text { fltrd } \\
(\mu \mathrm{g} / \mathrm{L})\end{array}$ & $\begin{array}{c}\text { MCPB, } \\
\text { water, } \\
\text { fltrd } \\
(\mu \mathrm{g} / \mathrm{L})\end{array}$ & $\begin{array}{l}\text { Metalaxyl, } \\
\text { water, } \\
\text { fltrd } \\
(\mu \mathrm{g} / \mathrm{L})\end{array}$ & $\begin{array}{l}\text { Methidathion, } \\
\text { water, } \\
\text { fltrd } \\
(\mu \mathrm{g} / \mathrm{L})\end{array}$ & $\begin{array}{c}\text { Methiocarb, } \\
\text { water, } \\
\text { fltrd } \\
(\mu \mathrm{g} / \mathrm{L})\end{array}$ & $\begin{array}{l}\text { Methomyl, } \\
\text { water, } \\
\text { fltrd } \\
(\mu \mathrm{g} / \mathrm{L})\end{array}$ & $\begin{array}{c}\text { Methyl } \\
\text { paraoxon, } \\
\text { water, fltrd } \\
(\mu \mathrm{g} / \mathrm{L})\end{array}$ \\
\hline
\end{tabular}

Station 08211511-Texas AgriLife Research at Corpus Christi, Tex.

Mar. 28, 2006

Oct. 25, 2007

Station 08211517-West Oso Creek at Merrett Road near Corpus Christi, Tex.

\begin{tabular}{llllllll}
\hline Nov. 11, 2006 Blank & $<0.06$ & $<0.2$ & $<0.04$ & $<0.007$ & $<0.04$ & $<0.06<0.02$
\end{tabular}

Oct. 25,2007

Station 08211525-Unnamed Oso Creek tributary at Farm Road 2444 near Corpus Christi, Tex.

Mar. 28, 2006 
Appendix 1. Quality control and assurance data for rainfall samples collected at Texas AgriLife Research at Corpus Christi (station 08211511); and for runoff samples collected at West Oso Creek (station 08211517) and Oso Creek tributary (station 08211525), Nueces County, Texas, water years 2006-08-Continued.

\begin{tabular}{|c|c|c|c|c|c|c|c|c|}
\hline Date & Sample type & $\begin{array}{c}\text { Methyl } \\
\text { parathion, } \\
\text { water, fltrd } \\
(\mu \mathrm{g} / \mathrm{L})\end{array}$ & $\begin{array}{c}\text { Metolachlor, } \\
\text { water, } \\
\text { fltrd } \\
(\mu \mathrm{g} / \mathrm{L})\end{array}$ & $\begin{array}{l}\text { Metribuzin, } \\
\text { water, } \\
\text { fltrd } \\
(\mu \mathrm{g} / \mathrm{L})\end{array}$ & $\begin{array}{c}\text { Metsulfuron, } \\
\text { water, } \\
\text { fltrd } \\
(\mu \mathrm{g} / \mathrm{L})\end{array}$ & $\begin{array}{c}\text { Myclobutanil, } \\
\text { water, } \\
\text { fltrd } \\
(\mu \mathrm{g} / \mathrm{L})\end{array}$ & $\begin{array}{c}\mathrm{N}-(4-C h l o r o- \\
\text { phenyl)-N'- } \\
\text { methylurea } \\
(\mu \mathrm{g} / \mathrm{L})\end{array}$ & $\begin{array}{c}\text { Neburon, } \\
\text { water, } \\
\text { fltrd } \\
(\mu \mathrm{g} / \mathrm{L})\end{array}$ \\
\hline \multicolumn{9}{|c|}{ Station 08211511-Texas AgriLife Research at Corpus Christi, Tex. } \\
\hline Mar. 28, 2006 & -- & -- & -- & -- & -- & -- & -- & -- \\
\hline Oct. 25, 2007 & -- & -- & -- & -- & -- & -- & -- & -- \\
\hline \multicolumn{9}{|c|}{ Station 08211517-West 0so Creek at Merrett Road near Corpus Christi, Tex. } \\
\hline Nov. 11, 2006 & Blank & $<0.008$ & $<0.010$ & $<0.012$ & $<0.14$ & $<0.033$ & $<0.06$ & $<0.02$ \\
\hline Oct. 25, 2007 & -- & -- & -- & -- & -- & -- & -- & -- \\
\hline \multicolumn{9}{|c|}{ Station 08211525-Unnamed Oso Creek tributary at Farm Road 2444 near Corpus Christi, Tex. } \\
\hline Mar. 28, 2006 & -- & -- & -- & -- & -- & -- & -- & -- \\
\hline Date & Sample type & $\begin{array}{c}\text { Nicosul- } \\
\text { furon, } \\
\text { water, fltrd } \\
(\mu \mathrm{g} / \mathrm{L})\end{array}$ & $\begin{array}{c}\text { Norflurazon, } \\
\text { water, } \\
\text { fltrd } \\
(\mu \mathrm{g} / \mathrm{L}) \\
\end{array}$ & $\begin{array}{c}\text { Oryzalin, } \\
\text { water, } \\
\text { fltrd } \\
(\mu \mathrm{g} / \mathrm{L})\end{array}$ & $\begin{array}{c}\text { Oxamyl, } \\
\text { water, } \\
\text { fltrd } \\
(\mu \mathrm{g} / \mathrm{L})\end{array}$ & $\begin{array}{c}\text { Pendi- } \\
\text { methalin, } \\
\text { water, fltrd } \\
(\mu \mathrm{g} / \mathrm{L})\end{array}$ & $\begin{array}{c}\text { Phorate } \\
\text { oxon, } \\
\text { water, fltrd } \\
(\mu \mathrm{g} / \mathrm{L})\end{array}$ & $\begin{array}{c}\text { Phorate, } \\
\text { water, } \\
\text { fltrd } \\
(\mu \mathrm{g} / \mathrm{L}))\end{array}$ \\
\hline \multicolumn{9}{|c|}{ Station 08211511-Texas AgriLife Research at Corpus Christi, Tex. } \\
\hline Mar. 28, 2006 & -- & -- & -- & -- & -- & -- & -- & -- \\
\hline Oct. 25, 2007 & -- & -- & -- & -- & -- & -- & -- & -- \\
\hline
\end{tabular}

Station 08211517-West 0so Creek at Merrett Road near Corpus Christi, Tex.

\begin{tabular}{lllllll}
\hline Nov. 11, 2006 Blank & $<0.10$ & $<0.04$ & $<0.04$ & $<0.04$ & $<0.02<$
\end{tabular}

Oct. 25,2007

Station 08211525-Unnamed Oso Creek tributary at Farm Road 2444 near Corpus Christi, Tex.

Mar. 28, 2006

\begin{tabular}{|c|c|c|c|c|c|c|c|c|}
\hline Date & Sample type & $\begin{array}{c}\text { Phosmet } \\
\text { oxon, } \\
\text { water, fltrd } \\
(\mu \mathrm{g} / \mathrm{L})\end{array}$ & $\begin{array}{c}\text { Phosmet, } \\
\text { water, } \\
\text { fltrd } \\
(\mu \mathrm{g} / \mathrm{L})\end{array}$ & $\begin{array}{c}\text { Picloram, } \\
\text { water, } \\
\text { fltrd } \\
(\mu \mathrm{g} / \mathrm{L})\end{array}$ & $\begin{array}{c}\text { Prometon, } \\
\text { water, } \\
\text { fltrd } \\
(\mu \mathrm{g} / \mathrm{L})\end{array}$ & $\begin{array}{c}\text { Prometryn, } \\
\text { water, } \\
\text { fltrd } \\
(\mu \mathrm{g} / \mathrm{L})\end{array}$ & $\begin{array}{c}\text { Propyz- } \\
\text { amide, } \\
\text { water, fltrd } \\
(\mu \mathrm{g} / \mathrm{L})\end{array}$ & $\begin{array}{c}\text { Propham, } \\
\text { water, } \\
\text { fltrd } \\
(\mu \mathrm{g} / \mathrm{L})\end{array}$ \\
\hline \multicolumn{9}{|c|}{ Station 08211511-Texas AgriLife Research at Corpus Christi, Tex. } \\
\hline Mar. 28, 2006 & -- & -- & -- & -- & -- & -- & -- & -- \\
\hline
\end{tabular}

Station 08211517-West Oso Creek at Merrett Road near Corpus Christi, Tex.

\begin{tabular}{lllllll}
\hline Nov. 11, 2006 Blank & $<0.051<0.008$ & $<0.12$ & $<0.01$ & $<0.006$ & $<0.004<06$
\end{tabular}

Oct. 25,2007

Station 08211525—Unnamed Oso Creek tributary at Farm Road 2444 near Corpus Christi, Tex. 
Appendix 1. Quality control and assurance data for rainfall samples collected at Texas AgriLife Research at Corpus Christi (station 08211511); and for runoff samples collected at West Oso Creek (station 08211517) and Oso Creek tributary (station 08211525), Nueces County, Texas, water years 2006-08-Continued.

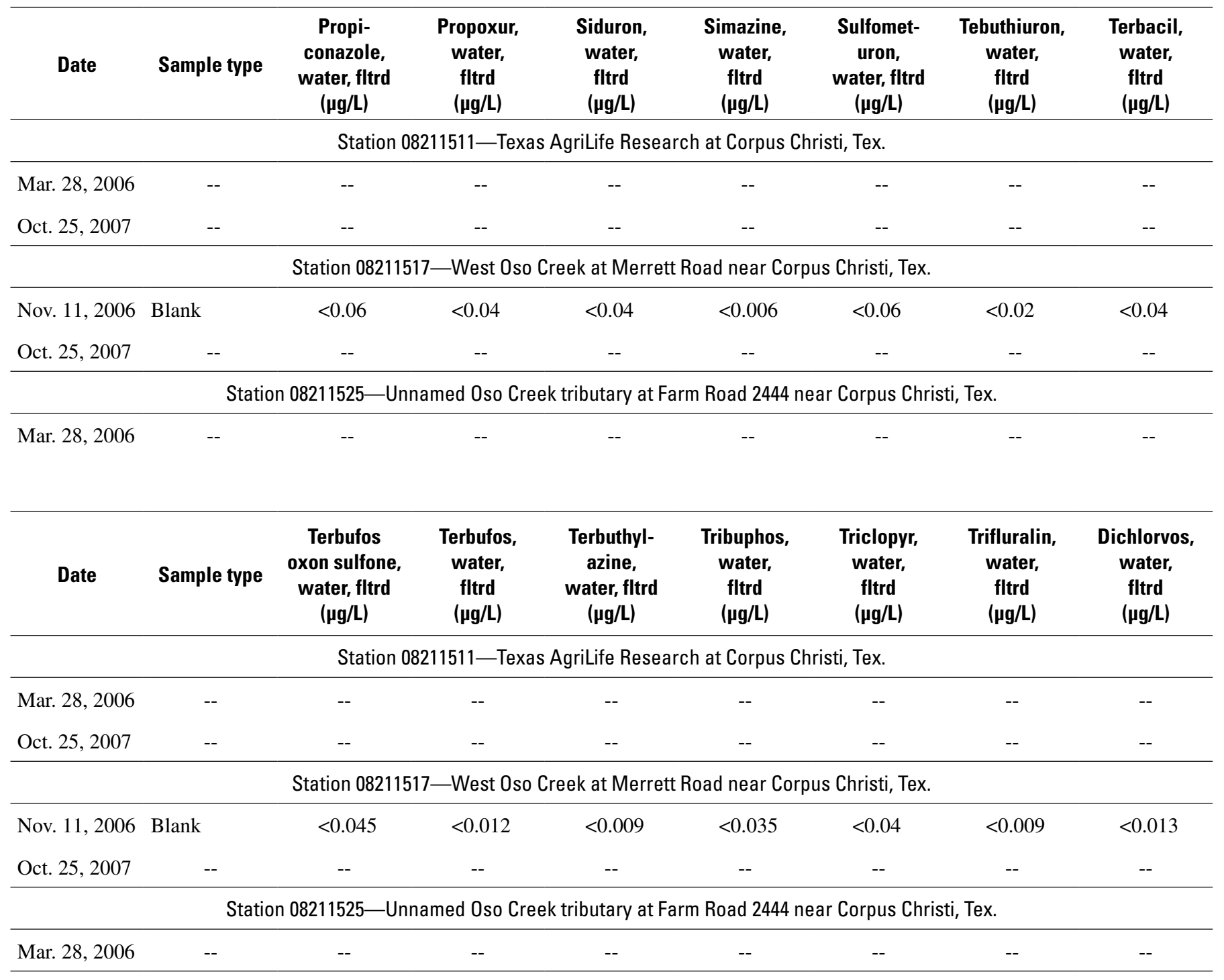


Appendix 2. Water-quality data for runoff samples collected at West Oso Creek (station 08211517), Nueces County, Texas, water years 2006-08.

[unfltrd, unfiltered; $\mu \mathrm{S} / \mathrm{cm}$, microsiemens per centimeter at 25 degrees Celsius; mg/L, milligrams per liter; CaCO ${ }_{3}$, calcium carbonate; fltrd, filtered; --, not analyzed; N, nitrogen; <, less than; P, phosphorus; $\mu \mathrm{g} / \mathrm{L}$, micrograms per liter; CIAT, 2-chloro-4-isopropylamino-6-amino-s-triazine; E, estimated; CEAT,

2-Chloro-6-ethylamino-4-amino-s-triazine; OIET, 2-hydroxy-4-isopropylamino-6-ethylamino-s-triazine; DCPA, Dimethyl tetrachloroterephthalate; MCPA, 4-chloro-2-methylphenoxy acetic acid; MCPB, 4-(2-methyl-4-chlorophenoxy)butyric acid]

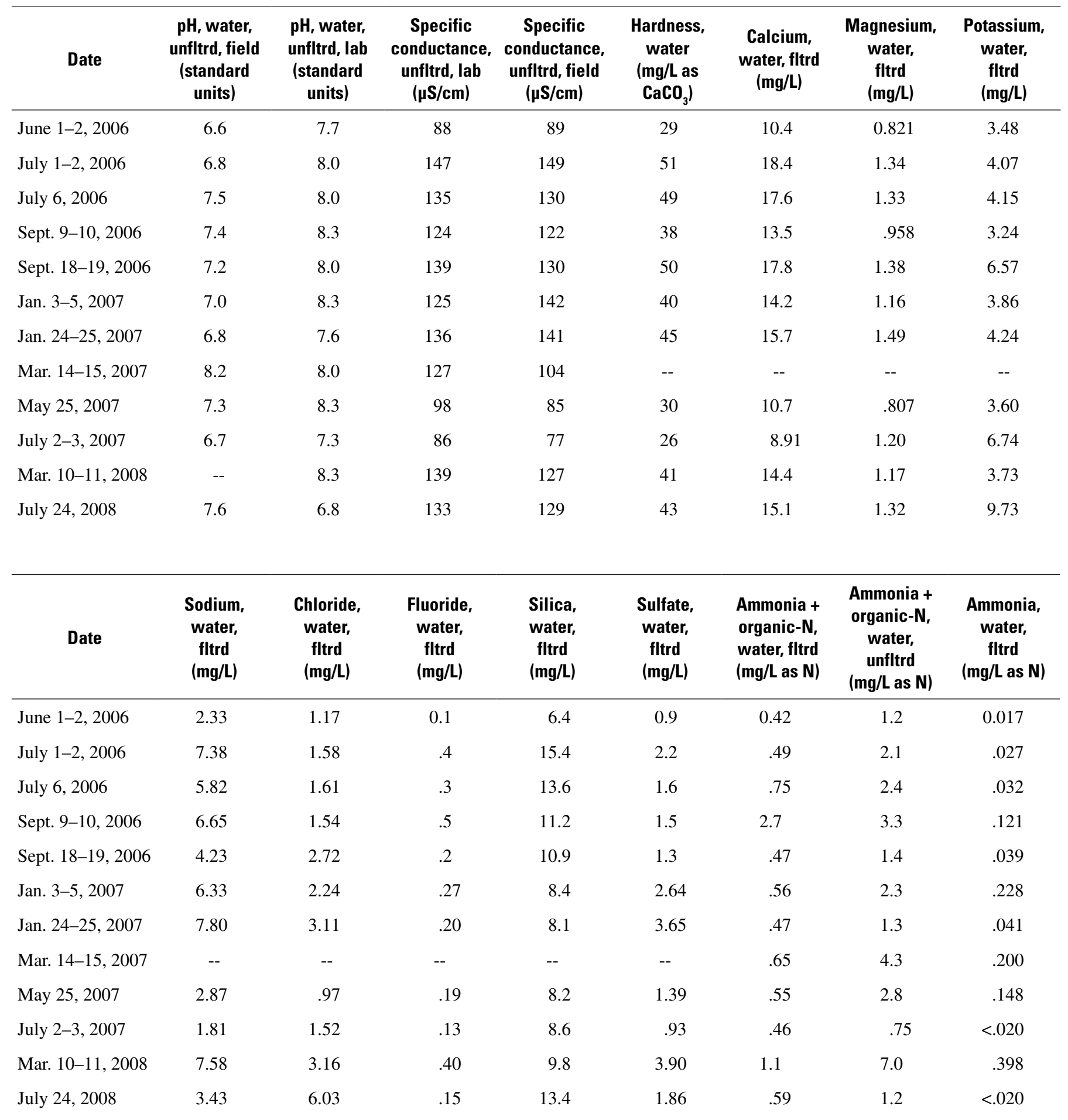


Appendix 2. Water-quality data for runoff samples collected at West 0so Creek (station 08211517), Nueces County, Texas, water years 2006-08-Continued.

\begin{tabular}{|c|c|c|c|c|c|c|c|c|c|}
\hline Date & $\begin{array}{c}\text { Nitrate, } \\
\text { water, } \\
\text { fltrd } \\
(\mathrm{mg} / \mathrm{L} \text { as } \mathrm{N})^{1}\end{array}$ & $\begin{array}{c}\text { Nitrite + } \\
\text { nitrate, } \\
\text { water, fltrd } \\
\text { (mg/L as } \mathrm{N} \text { ) }\end{array}$ & $\begin{array}{c}\text { Nitrite, } \\
\text { water, } \\
\text { fltrd } \\
\text { (mg/L as } N \text { ) }\end{array}$ & $\begin{array}{c}\text { Organic } \\
\text { nitrogen, } \\
\text { water, fltrd } \\
(\mathrm{mg} / \mathrm{L} \text { as } \mathrm{N})^{1}\end{array}$ & \multicolumn{2}{|c|}{$\begin{array}{c}\text { Organic } \\
\text { nitrogen, } \\
\text { water, unfltrd } \\
(\mathbf{m g} / \mathrm{L} \text { as } \mathrm{N})^{1}\end{array}$} & $\begin{array}{c}\text { Total } \\
\text { nitrogen, } \\
\text { water, fltrd } \\
(\mathrm{mg} / \mathrm{L} \text { as N})^{1}\end{array}$ & $\begin{array}{c}\text { Total } \\
\text { nitrogen, } \\
\text { water, unfltrd } \\
(\mathrm{mg} / \mathrm{L} \text { as } \mathrm{N})^{1}\end{array}$ & $\begin{array}{c}\text { Ortho- } \\
\text { phosphate, } \\
\text { water, fltrd } \\
\text { (mg/L as } P \text { ) }\end{array}$ \\
\hline June 1-2, 2006 & 0.23 & 0.25 & 0.017 & 0.41 & \multicolumn{2}{|c|}{1.2} & 0.67 & 1.5 & 0.167 \\
\hline July 1-2, 2006 & .44 & .49 & .049 & .47 & \multicolumn{2}{|c|}{2.1} & .98 & 2.6 & .216 \\
\hline July 6, 2006 & .36 & .38 & .026 & .72 & \multicolumn{2}{|c|}{2.3} & 1.1 & 2.8 & .264 \\
\hline Sept. 9-10, 2006 & .65 & .71 & .058 & 2.6 & \multicolumn{2}{|c|}{3.2} & 3.4 & 4.0 & .159 \\
\hline Sept. 18-19, 2006 & .49 & .51 & .017 & .43 & \multicolumn{2}{|c|}{1.4} & .97 & 1.9 & .251 \\
\hline Jan. 3-5, 2007 & 2.01 & 2.19 & .178 & .33 & \multicolumn{2}{|c|}{2.1} & 2.7 & 4.5 & .310 \\
\hline Jan. 24-25, 2007 & 3.13 & 3.26 & .123 & .43 & \multicolumn{2}{|c|}{1.3} & 3.7 & 4.6 & .252 \\
\hline Mar. 14-15, 2007 & .72 & .78 & .057 & .45 & \multicolumn{2}{|c|}{4.2} & 1.4 & 5.1 & .350 \\
\hline May 25, 2007 & .73 & .77 & .042 & .40 & \multicolumn{2}{|c|}{2.6} & 1.3 & 3.5 & .342 \\
\hline July 2-3, 2007 & .21 & .22 & .008 & .44 & \multicolumn{2}{|c|}{.73} & .68 & .98 & .463 \\
\hline Mar. 10-11, 2008 & 1.95 & 2.04 & .089 & .70 & \multicolumn{2}{|c|}{6.6} & 3.1 & 9.0 & .303 \\
\hline July 24, 2008 & .33 & .34 & .009 & -- & \multirow{2}{*}{\multicolumn{2}{|c|}{--}} & .94 & 1.6 & .332 \\
\hline \multicolumn{9}{|c|}{${ }^{1}$ Concentration of constituent not analyzed directly but computed from other analyzed constituents. } & \\
\hline Date & $\begin{array}{l}\text { Phosphorus, } \\
\text { water, } \\
\text { fltrd } \\
\text { (mg/L as } \mathrm{P} \text { ) }\end{array}$ & $\begin{array}{c}\text { Phosphorus, } \\
\text { water, } \\
\text { unfltrd } \\
\text { (mg/L as } \mathrm{P} \text { ) }\end{array}$ & $\begin{array}{c}\text { 1-Naphthol, } \\
\text { water, } \\
\text { fltrd } \\
(\mu \mathrm{g} / \mathrm{L})\end{array}$ & $\begin{array}{c}\text { 2,4-D } \\
\text { methylester, } \\
\text { water, fltrd } \\
(\mu \mathrm{g} / \mathrm{L})\end{array}$ & $\begin{array}{c}2,4-D, \\
\text { water, } \\
\text { fltrd } \\
(\mu \mathrm{g} / \mathrm{L})\end{array}$ & $\begin{array}{c}\text { 2,4-DB, } \\
\text { water, } \\
\text { fltrd } \\
(\mu \mathrm{g} / \mathrm{L})\end{array}$ & $\begin{array}{c}\text { 2,6-Diethyl- } \\
\text { aniline, } \\
\text { water, fltrd } \\
(\mu \mathrm{g} / \mathrm{L})\end{array}$ & $\begin{array}{c}\text { 2-Chloro- } \\
\text { 2',6'-diethyl } \\
\text { acetanilide, } \\
\text { water, fltrd } \\
(\mu \mathrm{g} / \mathrm{L})\end{array}$ & $\begin{array}{c}\text { CIAT, } \\
\text { water, } \\
\text { fltrd } \\
(\mu \mathrm{g} / \mathrm{L})\end{array}$ \\
\hline June 1-2, 2006 & 0.189 & 0.47 & $<0.09$ & $<0.190$ & E0.06 & $<0.02$ & $<0.006$ & $<0.006$ & E0.112 \\
\hline July 1-2, 2006 & .25 & .80 & $<.09$ & $<.638$ & E6.24 & $<.02$ & $<.006$ & $<.006$ & E. 048 \\
\hline July 6, 2006 & .28 & .66 & $<.09$ & $<.190$ & E3.35 & $<.02$ & $<.006$ & $<.006$ & E. 030 \\
\hline Sept. 9-10, 2006 & .27 & .75 & $<.09$ & $<.190$ & $<.04$ & $<.02$ & $<.006$ & $<.006$ & E.109 \\
\hline Sept. 18-19, 2006 & .27 & .57 & $<.09$ & $<.190$ & .59 & $<.02$ & $<.006$ & $<.006$ & E.029 \\
\hline Jan. 3-5, 2007 & .35 & .78 & $<.09$ & $<.200$ & E. 12 & $<.02$ & $<.006$ & $<.006$ & E. 015 \\
\hline Jan. 24-25, 2007 & .257 & .52 & $<.09$ & $<.200$ & .16 & $<.02$ & $<.006$ & $<.006$ & E. 020 \\
\hline Mar. 14-15, 2007 & .367 & 1.52 & $<.09$ & $<.200$ & .04 & $<.02$ & $<.006$ & $<.006$ & E.021 \\
\hline May 25, 2007 & .40 & 1.00 & $<.09$ & $<.200$ & $<.04$ & $<.02$ & $<.006$ & $<.006$ & E.049 \\
\hline July 2-3, 2007 & .49 & .59 & $<.09$ & $<.200$ & $<.04$ & $<.02$ & $<.006$ & $<.006$ & E. 179 \\
\hline Mar. 10-11, 2008 & .33 & .29 & $<.04$ & $<.040$ & .28 & $<.02$ & $<.006$ & $<.010$ & E. 138 \\
\hline July 24, 2008 & .365 & .57 & $<.04$ & $<.040$ & $<.02$ & $<.02$ & $<.006$ & $<.010$ & E.149 \\
\hline
\end{tabular}


Appendix 2. Water-quality data for runoff samples collected at West Oso Creek (station 08211517), Nueces County, Texas, water years 2006-08-Continued.

\begin{tabular}{|c|c|c|c|c|c|c|c|c|c|}
\hline Date & $\begin{array}{c}\text { CEAT, } \\
\text { water, } \\
\text { fltrd } \\
(\mu \mathrm{g} / \mathrm{L})\end{array}$ & $\begin{array}{c}\text { 2-Ethyl-6- } \\
\text { methyl- } \\
\text { aniline } \\
\text { water, } \\
\text { fltrd } \\
(\mu \mathrm{g} / \mathrm{L})\end{array}$ & $\begin{array}{c}\text { OIET, } \\
\text { water, } \\
\text { fltrd } \\
(\mu \mathrm{g} / \mathrm{L})\end{array}$ & $\begin{array}{c}\text { 3,4-Di- } \\
\text { chloro- } \\
\text { aniline } \\
\text { water, } \\
\text { fltrd } \\
(\mu \mathrm{g} / \mathrm{L})\end{array}$ & $\begin{array}{c}\text { 3-Hydroxy } \\
\text { carbofuran, } \\
\text { water, } \\
\text { fltrd } \\
(\mu \mathrm{g} / \mathrm{L})\end{array}$ & $\begin{array}{c}\text { 4-Chloro- } \\
\text { 2-methyl } \\
\text { phenol, } \\
\text { water, } \\
\text { fltrd } \\
(\mu \mathrm{g} / \mathrm{L})\end{array}$ & $\begin{array}{l}\text { Acetochlor, } \\
\text { water, } \\
\text { fltrd } \\
(\mu \mathrm{g} / \mathrm{L})\end{array}$ & $\begin{array}{l}\text { Acifluorfen, } \\
\text { water, } \\
\text { fltrd } \\
(\mu \mathrm{g} / \mathrm{L})\end{array}$ & $\begin{array}{c}\text { Alachlor, } \\
\text { water, } \\
\text { fltrd } \\
(\mu \mathrm{g} / \mathrm{L})\end{array}$ \\
\hline June 1-2, 2006 & $<0.08$ & $<0.010$ & 0.242 & $<0.004$ & $<0.008$ & $<0.005$ & $<0.006$ & E0.008 & $<0.005$ \\
\hline July 1-2, 2006 & $<.08$ & $<.010$ & .100 & $<.004$ & $<.008$ & $<.005$ & $<.006$ & $<.028$ & $<.005$ \\
\hline July 6, 2006 & $<.08$ & $<.010$ & .111 & $<.004$ & $<.008$ & $<.005$ & $<.006$ & $<.028$ & $<.005$ \\
\hline Sept. 9-10, 2006 & E.04 & $<.010$ & E. 302 & $<.004$ & $<.008$ & $<.005$ & $<.006$ & $<.028$ & $<.005$ \\
\hline Sept. 18-19, 2006 & $<.08$ & $<.010$ & .106 & $<.004$ & $<.008$ & $<.005$ & $<.006$ & $<.028$ & $<.005$ \\
\hline Jan. 3-5, 2007 & $<.08$ & $<.010$ & E.063 & $<.004$ & $<.020$ & $<.005$ & $<.006$ & $<.006$ & $<.005$ \\
\hline Jan. 24-25, 2007 & $<.08$ & $<.010$ & E.065 & $<.004$ & $<.020$ & $<.005$ & $<.006$ & $<.006$ & $<.005$ \\
\hline Mar. 14-15, 2007 & $<.08$ & $<.010$ & .105 & $<.004$ & $<.020$ & $<.005$ & $<.006$ & $<.006$ & $<.005$ \\
\hline May 25, 2007 & $<.08$ & $<.010$ & .149 & $<.006$ & $<.020$ & $<.005$ & $<.006$ & $<.006$ & $<.005$ \\
\hline July 2-3, 2007 & E.07 & $<.010$ & .529 & $<.004$ & $<.020$ & $<.005$ & $<.006$ & $<.006$ & $<.005$ \\
\hline Mar. 10-11, 2008 & $<.08$ & $<.010$ & $<.040$ & $<.006$ & $<.040$ & $<.005$ & $<.006$ & $<.040$ & $<.006$ \\
\hline July 24, 2008 & $<.08$ & $<.010$ & .247 & $<.006$ & $<.040$ & $<.005$ & $<.006$ & $<.040$ & $<.006$ \\
\hline Date & $\begin{array}{c}\text { Aldicarb } \\
\text { sulfone, } \\
\text { water, } \\
\text { fltrd } \\
(\mu \mathrm{g} / \mathrm{L})\end{array}$ & $\begin{array}{c}\text { Aldicarb } \\
\text { sulfoxide, } \\
\text { water, } \\
\text { fltrd } \\
(\mu \mathrm{g} / \mathrm{L})\end{array}$ & $\begin{array}{c}\text { Aldicarb, } \\
\text { water, } \\
\text { fltrd } \\
(\mu \mathrm{g} / \mathrm{L})\end{array}$ & $\begin{array}{c}\text { Amino- } \\
\text { methyl- } \\
\text { phosphonic } \\
\text { acid, } \\
\text { water, } \\
\text { fltrd } \\
\text { ( } \mu \mathrm{g} / \mathrm{L})\end{array}$ & $\begin{array}{c}\text { Atrazine, } \\
\text { water, } \\
\text { fltrd } \\
(\mu \mathrm{g} / \mathrm{L})\end{array}$ & $\begin{array}{c}\text { Azinphos- } \\
\text { methyl } \\
\text { oxon, } \\
\text { water, } \\
\text { fltrd } \\
\text { ( } \mu \mathrm{g} / \mathrm{L})\end{array}$ & $\begin{array}{l}\text { Azinphos- } \\
\text { methyl, } \\
\text { water, } \\
\text { fltrd } \\
\text { ( } \mu \mathrm{g} / \mathrm{L})\end{array}$ & $\begin{array}{c}\text { Bendio- } \\
\text { carb, } \\
\text { water, } \\
\text { fltrd } \\
(\mu \mathrm{g} / \mathrm{L})\end{array}$ & $\begin{array}{c}\text { Benfluralin, } \\
\text { water, } \\
\text { fltrd } \\
(\mu \mathrm{g} / \mathrm{L})\end{array}$ \\
\hline June 1-2, 2006 & $<0.02$ & E0.006 & $<0.15$ & 1.34 & 0.996 & $<0.04$ & $<0.050$ & $<0.08$ & $<0.010$ \\
\hline July 1-2, 2006 & $<.02$ & $<.100$ & $<.15$ & 13.2 & .097 & $<.04$ & $<.050$ & $<.08$ & $<.010$ \\
\hline July 6, 2006 & $<.02$ & $<.100$ & $<.15$ & 4.69 & .053 & $<.04$ & $<.050$ & $<.08$ & $<.010$ \\
\hline Sept. 9-10, 2006 & $<.02$ & $<.100$ & $<.15$ & 10.3 & .192 & $<.04$ & $<.050$ & $<.08$ & $<.010$ \\
\hline Sept. 18-19, 2006 & $<.02$ & $<.100$ & $<.15$ & 1.13 & .030 & $<.04$ & $<.050$ & $<.08$ & $<.010$ \\
\hline Jan. 3-5, 2007 & $<.08$ & $<.040$ & $<.04$ & 2.50 & .022 & $<.04$ & $<.080$ & $<.04$ & E.007 \\
\hline Jan. 24-25, 2007 & $<.08$ & $<.040$ & $<.04$ & 1.33 & .056 & $<.04$ & $<.080$ & $<.04$ & $<.010$ \\
\hline Mar. 14-15, 2007 & $<.08$ & $<.040$ & $<.04$ & 1.60 & .252 & $<.04$ & $<.080$ & $<.04$ & $<.010$ \\
\hline May 25, 2007 & $<.08$ & $<.040$ & $<.04$ & 10.1 & .144 & $<.04$ & $<.080$ & $<.04$ & $<.010$ \\
\hline July 2-3, 2007 & $<.08$ & $<.040$ & $<.04$ & 8.20 & 8.90 & $<.04$ & $<.080$ & $<.04$ & $<.010$ \\
\hline Mar. 10-11, 2008 & $<.08$ & $<.060$ & $<.12$ & -- & E.939 & $<.04$ & $<.120$ & $<.04$ & $<.010$ \\
\hline July 24, 2008 & $<.08$ & $<.060$ & $<.12$ & -- & .091 & $<.06$ & $<.120$ & $<.04$ & $<.010$ \\
\hline
\end{tabular}


Appendix 2. Water-quality data for runoff samples collected at West 0so Creek (station 08211517), Nueces County, Texas, water years 2006-08-Continued.

\begin{tabular}{|c|c|c|c|c|c|c|c|c|c|}
\hline Date & $\begin{array}{c}\text { Benomyl } \\
\text { water, } \\
\text { fltrd } \\
(\mu \mathrm{g} / \mathrm{L})\end{array}$ & $\begin{array}{c}\text { Bensulfuron } \\
\text { methyl, } \\
\text { water, } \\
\text { fltrd } \\
(\mu \mathrm{g} / \mathrm{L})\end{array}$ & $\begin{array}{c}\text { Bentazon, } \\
\text { water, } \\
\text { fltrd } \\
(\mu \mathrm{gg} / \mathrm{L})\end{array}$ & $\begin{array}{c}\text { Bromacil, } \\
\text { water, } \\
\text { fltrd } \\
(\mu \mathrm{g} / \mathrm{L})\end{array}$ & \multicolumn{2}{|c|}{$\begin{array}{c}\text { Bromoxynil, } \\
\text { water, } \\
\text { fltrd } \\
(\mu \mathrm{g} / \mathrm{L})\end{array}$} & $\begin{array}{c}\text { Carbaryl, } \\
\text { water, } \\
\text { fltrd } \\
(\mu \mathrm{g} / \mathrm{L})\end{array}$ & $\begin{array}{l}\text { Carbofuran, } \\
\text { water, } \\
\text { fltrd } \\
(\mu \mathrm{g} / \mathrm{L})\end{array}$ & $\begin{array}{c}\text { Chloramben } \\
\text { methyl } \\
\text { ester, } \\
\text { water, } \\
\text { fltrd } \\
(\mu \mathrm{g} / \mathrm{L})\end{array}$ \\
\hline June 1-2, 2006 & $<0.022$ & $<0.02$ & $<0.02$ & $<0.0$ & $<0$ & & $<0.02$ & $<0.016$ & $<0.02$ \\
\hline July 1-2, 2006 & $<.022$ & $<.02$ & $<.02$ & $<.0$ & $<$ & 04 & $<.02$ & $<.016$ & $<.02$ \\
\hline July 6, 2006 & $<.022$ & $<.02$ & $<.02$ & $<.0$ & $<$ & 04 & $<.02$ & $<.016$ & $<.02$ \\
\hline Sept. 9-10, 2006 & $<.022$ & $<.02$ & $<.02$ & $<.0$ & $<$ & 04 & $<.02$ & $<.016$ & $<.02$ \\
\hline Sept. 18-19, 2006 & $<.022$ & $<.02$ & $<.02$ & $<.0$ & $<$ & 04 & $<.02$ & $<.016$ & $<.02$ \\
\hline Jan. 3-5, 2007 & $<.020$ & $<.06$ & $<.02$ & $<.0$ & $<$ & 12 & $<.02$ & $<.060$ & $<.10$ \\
\hline Jan. 24-25, 2007 & $<.020$ & $<.06$ & $<.02$ & $<.0$ & $<$ & 12 & $<.02$ & $<.060$ & $<.10$ \\
\hline Mar. 14-15, 2007 & $<.020$ & $<.06$ & $<.02$ & $<.0$ & $<$ & 12 & $<.02$ & $<.060$ & $<.10$ \\
\hline May 25, 2007 & $<.020$ & $<.06$ & $<.02$ & $<.0$ & & 12 & $<.02$ & $<.060$ & $<.10$ \\
\hline July 2-3, 2007 & $<.020$ & $<.06$ & $<.02$ & $<.0$ & $<$ & 12 & $<.02$ & $<.060$ & $<.10$ \\
\hline Mar. 10-11, 2008 & $<.040$ & $<.06$ & $<.04$ & $<.0$ & $<$ & 12 & $<.04$ & $<.020$ & $<.10$ \\
\hline July 24,2008 & $<.040$ & $<.06$ & $<.04$ & $<.0$ & & 12 & $<.04$ & $<.020$ & $<.10$ \\
\hline Date & $\begin{array}{c}\text { Chlori- } \\
\text { muron, } \\
\text { water, } \\
\text { fltrd } \\
(\mu \mathrm{g} / \mathrm{L})\end{array}$ & $\begin{array}{c}\text { Chloro- } \\
\text { diamino- } \\
\text { s-triazine, } \\
\text { water, } \\
\text { fltrd } \\
(\mu \mathrm{g} / \mathrm{L})\end{array}$ & $\begin{array}{c}\text { Chlor- } \\
\text { pyrifos } \\
\text { oxon, } \\
\text { water, } \\
\text { fltrd } \\
\text { ( } \mu \mathrm{g} / \mathrm{L})\end{array}$ & $\begin{array}{l}\text { Chlorpy- } \\
\text { rifos } \\
\text { water, } \\
\text { fltrd } \\
(\mu \mathrm{g} / \mathrm{L})\end{array}$ & $\begin{array}{c}\text { cis- } \\
\text { Permethrin, } \\
\text { water, } \\
\text { fltrd } \\
(\mu \mathrm{g} / \mathrm{L})\end{array}$ & $\begin{array}{c}\text { Clopyralid, } \\
\text { water, } \\
\text { fltrd } \\
(\mu \mathrm{g} / \mathrm{L})\end{array}$ & $\begin{array}{c}\text { Cycloate, } \\
\text { water, } \\
\text { fltrd } \\
(\mu \mathrm{g} / \mathrm{L})\end{array}$ & $\begin{array}{l}\text { Cyfluthrin, } \\
\text { water, } \\
\text { fltrd } \\
(\mu \mathrm{g} / \mathrm{L})\end{array}$ & $\begin{array}{c}\text { Cyper- } \\
\text { methrin, } \\
\text { water, } \\
\text { fltrd } \\
(\mu \mathrm{g} / \mathrm{L})\end{array}$ \\
\hline June 1-2, 2006 & $<0.032$ & $<0.04$ & $<0.06$ & $<0.006$ & $<0.006$ & $<0.07$ & $<0.01$ & $<0.053$ & $<0.046$ \\
\hline July 1-2, 2006 & $<.032$ & $<.04$ & $<.06$ & $<.005$ & $<.006$ & $<.07$ & $<.01$ & $<.053$ & $<.046$ \\
\hline July 6, 2006 & $<.032$ & $<.04$ & $<.06$ & $<.005$ & $<.006$ & $<.07$ & $<.01$ & $<.053$ & $<.046$ \\
\hline Sept. 9-10, 2006 & $<.032$ & $<.04$ & $<.06$ & $<.005$ & $<.006$ & $<.07$ & $<.01$ & $<.053$ & $<.046$ \\
\hline Sept. 18-19, 2006 & $<.032$ & $<.04$ & $<.06$ & $<.005$ & $<.006$ & $<.07$ & $<.01$ & $<.053$ & $<.046$ \\
\hline Jan. 3-5, 2007 & $<.080$ & $<.12$ & $<.06$ & $<.005$ & $<.010$ & $<.06$ & $<.06$ & $<.053$ & $<.046$ \\
\hline Jan. 24-25, 2007 & $<.080$ & $<.12$ & $<.06$ & $<.005$ & $<.010$ & $<.06$ & $<.06$ & $<.053$ & $<.046$ \\
\hline Mar. 14-15, 2007 & $<.080$ & $<.12$ & $<.06$ & $<.005$ & $<.010$ & $<.06$ & $<.06$ & $<.053$ & $<.046$ \\
\hline May 25, 2007 & $<.080$ & $<.12$ & $<.06$ & $<.011$ & $<.010$ & $<.06$ & $<.06$ & $<.053$ & $<.046$ \\
\hline July 2-3, 2007 & $<.080$ & $<.12$ & $<.06$ & $<.005$ & $<.010$ & $<.06$ & $<.06$ & $<.053$ & $<.046$ \\
\hline Mar. 10-11, 2008 & $<.080$ & -- & $<.06$ & $<.005$ & $<.010$ & $<.06$ & $<.02$ & $<.016$ & $<.014$ \\
\hline July 24,2008 & $<.080$ & -- & $<.06$ & $<.005$ & $<.010$ & $<.06$ & $<.02$ & $<.016$ & $<.014$ \\
\hline
\end{tabular}


Appendix 2. Water-quality data for runoff samples collected at West Oso Creek (station 08211517), Nueces County, Texas, water years 2006-08-Continued.

\begin{tabular}{|c|c|c|c|c|c|c|c|c|c|}
\hline Date & $\begin{array}{c}\text { Dacthal } \\
\text { mono-acid, } \\
\text { water, } \\
\text { fltrd } \\
(\mu \mathrm{g} / \mathrm{L})\end{array}$ & $\begin{array}{c}\text { DCPA, } \\
\text { water, } \\
\text { fltrd } \\
(\mu \mathrm{g} / \mathrm{L})\end{array}$ & $\begin{array}{c}\text { Desulfinyl- } \\
\text { fipronil, } \\
\text { water, } \\
\text { fltrd } \\
(\mu \mathrm{g} / \mathrm{L})\end{array}$ & $\begin{array}{c}\text { Diazinon, } \\
\text { water, } \\
\text { fltrd } \\
(\mu \mathrm{g} / \mathrm{L})\end{array}$ & $\begin{array}{c}\text { Dicamba, } \\
\text { water, } \\
\text { fltrd } \\
(\mu \mathrm{g} / \mathrm{L})\end{array}$ & $\begin{array}{c}\text { Dichlor- } \\
\text { prop, } \\
\text { water, } \\
\text { fltrd } \\
(\mu \mathrm{g} / \mathrm{L})\end{array}$ & $\begin{array}{c}\text { Dicroto- } \\
\text { phos, } \\
\text { water, } \\
\text { fltrd } \\
(\mu \mathrm{g} / \mathrm{L})\end{array}$ & $\begin{array}{c}\text { Dieldrin, } \\
\text { water, } \\
\text { fltrd } \\
(\mu \mathrm{g} / \mathrm{L})\end{array}$ & $\begin{array}{c}\text { Dimetho- } \\
\text { ate, } \\
\text { water, } \\
\text { fltrd } \\
(\mu \mathrm{g} / \mathrm{L})\end{array}$ \\
\hline June 1-2, 2006 & $<0.03$ & $<0.003$ & $<0.012$ & $<0.005$ & $<0.04$ & $<0.03$ & $<0.08$ & $<0.009$ & $<0.006$ \\
\hline July 1-2, 2006 & $<.03$ & $<.003$ & $<.012$ & $<.005$ & $<.04$ & $<.03$ & $<.08$ & $<.009$ & $<.006$ \\
\hline July 6, 2006 & $<.03$ & $<.003$ & $<.012$ & $<.005$ & $<.04$ & $<.03$ & $<.08$ & $<.009$ & $<.006$ \\
\hline Sept. 9-10, 2006 & $<.03$ & $<.003$ & $<.012$ & $<.005$ & $<.04$ & $<.03$ & $<.08$ & $<.009$ & $<.006$ \\
\hline Sept. 18-19, 2006 & $<.03$ & E.004 & $<.012$ & $<.005$ & $<.04$ & $<.03$ & $<.08$ & $<.009$ & $<.006$ \\
\hline Jan. 3-5, 2007 & $<.02$ & $<.003$ & $<.012$ & $<.005$ & $<.08$ & $<.04$ & $<.08$ & $<.009$ & $<.006$ \\
\hline Jan. 24-25, 2007 & $<.02$ & $<.003$ & $<.012$ & $<.005$ & $<.08$ & $<.04$ & $<.08$ & $<.009$ & $<.006$ \\
\hline Mar. 14-15, 2007 & $<.02$ & E.004 & $<.012$ & $<.005$ & $<.08$ & $<.04$ & $<.08$ & $<.009$ & $<.006$ \\
\hline May 25, 2007 & $<.02$ & $<.003$ & $<.012$ & $<.005$ & $<.08$ & $<.04$ & $<.08$ & $<.009$ & $<.006$ \\
\hline July 2-3, 2007 & $<.02$ & $<.003$ & $<.012$ & $<.005$ & $<.08$ & $<.04$ & E.04 & $<.009$ & $<.006$ \\
\hline Mar. 10-11, 2008 & $<.02$ & $<.003$ & $<.012$ & $<.005$ & $<.04$ & $<.02$ & $<.08$ & $<.009$ & $<.006$ \\
\hline July 24, 2008 & $<.02$ & $<.003$ & $<.012$ & $<.005$ & $<.04$ & $<.02$ & $<.08$ & $<.009$ & $<.006$ \\
\hline
\end{tabular}

\begin{tabular}{|c|c|c|c|c|c|c|c|c|c|}
\hline Date & $\begin{array}{c}\text { Dinoseb, } \\
\text { water, } \\
\text { fltrd } \\
(\mu \mathrm{g} / \mathrm{L})\end{array}$ & $\begin{array}{c}\text { Diphena- } \\
\text { mid, } \\
\text { water, } \\
\text { fltrd } \\
(\mu \mathrm{g} / \mathrm{L})\end{array}$ & $\begin{array}{c}\text { Diuron, } \\
\text { water, } \\
\text { fltrd } \\
(\mu \mathrm{g} / \mathrm{L})\end{array}$ & $\begin{array}{c}\text { Ethion } \\
\text { monoxon, } \\
\text { water, } \\
\text { fltrd } \\
(\mu \mathrm{g} / \mathrm{L})\end{array}$ & $\begin{array}{l}\text { Ethion, } \\
\text { water, } \\
\text { fltrd } \\
(\mu \mathrm{g} / \mathrm{L})\end{array}$ & $\begin{array}{l}\text { Fenami- } \\
\text { phos } \\
\text { sulfone, } \\
\text { water, } \\
\text { fltrd } \\
(\mu \mathrm{g} / \mathrm{L})\end{array}$ & $\begin{array}{c}\text { Fenami- } \\
\text { phos } \\
\text { sulfoxide, } \\
\text { water, } \\
\text { fltrd } \\
(\mu \mathrm{g} / \mathrm{L})\end{array}$ & $\begin{array}{l}\text { Fenami- } \\
\text { phos, } \\
\text { water, } \\
\text { fltrd } \\
(\mu \mathrm{g} / \mathrm{L})\end{array}$ & $\begin{array}{c}\text { Fenuron, } \\
\text { water, } \\
\text { fltrd } \\
(\mu \mathrm{g} / \mathrm{L})\end{array}$ \\
\hline June 1-2, 2006 & $<0.04$ & $<0.01$ & $<0.01$ & $<0.02$ & $<0.016$ & $<0.053$ & $<0.04$ & $<0.03$ & $<0.10$ \\
\hline July 1-2, 2006 & $<.04$ & $<.01$ & $<.02$ & $<.02$ & $<.016$ & $<.053$ & $<.04$ & $<.03$ & $<.10$ \\
\hline July 6, 2006 & $<.04$ & $<.01$ & .03 & $<.02$ & $<.016$ & $<.053$ & $<.04$ & $<.03$ & $<.10$ \\
\hline Sept. 9-10, 2006 & $<.04$ & $<.01$ & $<.02$ & $<.02$ & $<.016$ & $<.053$ & $<.04$ & $<.03$ & $<.10$ \\
\hline Sept. 18-19, 2006 & $<.04$ & $<.01$ & $<.02$ & $<.02$ & $<.016$ & $<.053$ & $<.04$ & $<.03$ & $<.10$ \\
\hline Jan. 3-5, 2007 & $<.04$ & $<.04$ & $<.04$ & $<.02$ & $<.016$ & $<.053$ & $<.04$ & $<.03$ & $<.04$ \\
\hline Jan. 24-25, 2007 & $<.04$ & $<.04$ & $<.04$ & $<.02$ & $<.016$ & $<.053$ & $<.04$ & $<.03$ & $<.04$ \\
\hline Mar. 14-15, 2007 & $<.04$ & $<.04$ & E.04 & $<.02$ & $<.016$ & $<.053$ & $<.04$ & $<.03$ & $<.04$ \\
\hline May 25, 2007 & $<.04$ & $<.04$ & $<.04$ & $<.02$ & $<.016$ & $<.053$ & $<.04$ & $<.03$ & $<.04$ \\
\hline July 2-3, 2007 & $<.04$ & $<.04$ & $<.04$ & $<.02$ & $<.016$ & $<.053$ & $<.04$ & $<.03$ & $<.04$ \\
\hline Mar. 10-11, 2008 & $<.04$ & $<.04$ & .08 & $<.02$ & $<.016$ & $<.053$ & $<.20$ & $<.03$ & $<.04$ \\
\hline July 24, 2008 & $<.04$ & $<.04$ & $<.04$ & $<.02$ & $<.016$ & $<.053$ & $<.20$ & $<.03$ & $<.04$ \\
\hline
\end{tabular}


Appendix 2. Water-quality data for runoff samples collected at West 0so Creek (station 08211517), Nueces County, Texas, water years 2006-08-Continued.

\begin{tabular}{|c|c|c|c|c|c|c|c|c|c|}
\hline Date & $\begin{array}{l}\text { Desulfinyl- } \\
\text { fipronil } \\
\text { amide, } \\
\text { water, fltrd } \\
(\mu \mathrm{g} / \mathrm{L})\end{array}$ & $\begin{array}{c}\text { Fipronil } \\
\text { sulfide, } \\
\text { water, } \\
\text { fltrd } \\
(\mu \mathrm{g} / \mathrm{L}) \\
\end{array}$ & $\begin{array}{c}\text { Fipronil } \\
\text { sulfone, } \\
\text { water, } \\
\text { fltrd } \\
(\mu \mathrm{g} / \mathrm{L})\end{array}$ & $\begin{array}{c}\text { Fipronil, } \\
\text { water, } \\
\text { fltrd } \\
(\mu \mathrm{g} / \mathrm{L})\end{array}$ & $\begin{array}{c}\text { Flumet- } \\
\text { sulam, } \\
\text { water, } \\
\text { fltrd } \\
(\mu \mathrm{g} / \mathrm{L})\end{array}$ & $\begin{array}{c}\text { Fluo- } \\
\text { meturon, } \\
\text { water, } \\
\text { fltrd } \\
\text { ( } \mathrm{gg} / \mathrm{L})\end{array}$ & $\begin{array}{c}\text { Fonofos, } \\
\text { water, } \\
\text { fltrd } \\
(\mu \mathrm{g} / \mathrm{L})\end{array}$ & $\begin{array}{c}\text { Glufos- } \\
\text { inate, } \\
\text { water, } \\
\text { fltrd } \\
(\mu \mathrm{g} / \mathrm{L})\end{array}$ & $\begin{array}{l}\text { Glyphosate, } \\
\text { water, } \\
\text { fltrd } \\
\text { ( } \mu \mathrm{g} / \mathrm{L})\end{array}$ \\
\hline June 1-2, 2006 & $<0.029$ & $<0.013$ & $<0.024$ & $<0.016$ & $<0.04$ & $<0.02$ & $<0.005$ & E0.120 & 1.81 \\
\hline July $1-2,2006$ & $<.029$ & $<.013$ & $<.024$ & $<.016$ & $<.04$ & $<.02$ & $<.005$ & $<.140$ & 51.2 \\
\hline July 6, 2006 & $<.029$ & $<.013$ & $<.024$ & $<.016$ & $<.04$ & $<.02$ & $<.005$ & $<.140$ & 11.8 \\
\hline Sept. 9-10, 2006 & $<.029$ & $<.013$ & $<.024$ & $<.016$ & $<.04$ & $<.02$ & $<.005$ & $<.140$ & 30.3 \\
\hline Sept. 18-19, 2006 & $<.029$ & $<.013$ & $<.024$ & $<.016$ & $<.04$ & $<.02$ & $<.005$ & $<.140$ & 2.00 \\
\hline Jan. 3-5, 2007 & $<.029$ & $<.016$ & $<.024$ & $<.016$ & $<.06$ & $<.04$ & $<.006$ & $<.140$ & 5.10 \\
\hline Jan. 24-25, 2007 & $<.029$ & $<.016$ & $<.024$ & $<.016$ & $<.06$ & $<.04$ & $<.006$ & $<.140$ & 2.10 \\
\hline Mar. 14-15, 2007 & $<.029$ & $<.016$ & $<.024$ & $<.016$ & $<.06$ & $<.04$ & $<.006$ & $<.140$ & E5.22 \\
\hline May 25, 2007 & $<.029$ & $<.016$ & $<.024$ & $<.016$ & $<.06$ & $<.04$ & $<.006$ & .580 & 53.5 \\
\hline July 2-3, 2007 & $<.029$ & $<.016$ & $<.024$ & $<.016$ & $<.06$ & $<.04$ & $<.006$ & $<.140$ & E12.6 \\
\hline Mar. 10-11, 2008 & $<.029$ & $<.013$ & $<.024$ & $<.020$ & $<.06$ & $<.04$ & $<.010$ & -- & -- \\
\hline July 24,2008 & $<.029$ & $<.013$ & $<.024$ & $<.020$ & $<.06$ & $<.04$ & $<.010$ & -- & -- \\
\hline Date & $\begin{array}{c}\text { Hexazi- } \\
\text { none, } \\
\text { water, } \\
\text { fltrd } \\
(\mu g / L)\end{array}$ & $\begin{array}{c}\text { Imazaquin, } \\
\text { water, } \\
\text { fltrd } \\
(\boldsymbol{\mu g} / \mathrm{L})\end{array}$ & $\begin{array}{l}\text { Imazethapyr, } \\
\text { water, } \\
\text { fltrd } \\
(\mu \mathrm{g} / \mathrm{L})\end{array}$ & $\begin{array}{l}\text { Imidacloprid, } \\
\text { water, } \\
\text { fltrd } \\
(\mu \mathrm{g} / \mathrm{L})\end{array}$ & $\begin{array}{c}\text { Iprodione, } \\
\text { water, } \\
\text { fltrd } \\
(\boldsymbol{\mu g} / \mathrm{L})\end{array}$ & $\begin{array}{l}\text { Isofenphos, } \\
\text { water, } \\
\text { fltrd } \\
(\mu \mathrm{g} / \mathrm{L})\end{array}$ & $\begin{array}{c}\text { Linuron, } \\
\text { water, } \\
\text { fltrd } \\
(\mu \mathrm{g} / \mathrm{L})\end{array}$ & $\begin{array}{c}\text { Malaoxon, } \\
\text { water, } \\
\text { fltrd } \\
(\mu \mathrm{g} / \mathrm{L})\end{array}$ & $\begin{array}{c}\text { Malathion, } \\
\text { water, } \\
\text { fltrd } \\
(\mu \mathrm{g} / \mathrm{L})\end{array}$ \\
\hline June 1-2, 2006 & $<0.026$ & $<0.04$ & $<0.04$ & $<0.020$ & $<0.026$ & $<0.011$ & $<0.01$ & $<0.039$ & $<0.027$ \\
\hline July $1-2,2006$ & $<.026$ & $<.04$ & $<.04$ & $<.020$ & $<.026$ & $<.011$ & $<.01$ & $<.039$ & $<.027$ \\
\hline July 6, 2006 & $<.026$ & $<.04$ & $<.04$ & $<.020$ & $<.026$ & $<.011$ & $<.01$ & $<.039$ & $<.027$ \\
\hline Sept. 9-10, 2006 & $<.026$ & $<.04$ & $<.04$ & $<.020$ & $<.026$ & $<.011$ & $<.01$ & $<.039$ & $<.027$ \\
\hline Sept. 18-19, 2006 & $<.026$ & $<.04$ & $<.04$ & $<.020$ & $<.026$ & $<.011$ & $<.01$ & $<.039$ & $<.027$ \\
\hline Jan. 3-5, 2007 & $<.026$ & $<.04$ & $<.04$ & $<.060$ & $<.026$ & $<.011$ & $<.04$ & $<.039$ & $<.016$ \\
\hline Jan. 24-25, 2007 & $<.026$ & $<.04$ & $<.04$ & $<.060$ & $<.026$ & $<.011$ & $<.04$ & $<.039$ & $<.016$ \\
\hline Mar. 14-15, 2007 & $<.026$ & $<.04$ & $<.04$ & .086 & $<.026$ & $<.011$ & $<.04$ & $<.039$ & $<.016$ \\
\hline May 25, 2007 & $<.026$ & $<.04$ & $<.04$ & $<.078$ & $<.026$ & $<.011$ & $<.04$ & $<.039$ & $<.016$ \\
\hline July 2-3, 2007 & $<.026$ & $<.04$ & $<.04$ & $<.060$ & $<.026$ & $<.011$ & $<.04$ & $<.039$ & $<.016$ \\
\hline Mar. 10-11, 2008 & $<.008$ & $<.04$ & $<.04$ & $<.060$ & $<.01$ & $<.006$ & $<.02$ & $<.020$ & $<.016$ \\
\hline July 24, 2008 & $<.008$ & $<.04$ & $<.04$ & $<.060$ & $<.01$ & $<.006$ & $<.02$ & $<.020$ & $<.016$ \\
\hline
\end{tabular}


Appendix 2. Water-quality data for runoff samples collected at West Oso Creek (station 08211517), Nueces County, Texas, water years 2006-08-Continued.

\begin{tabular}{|c|c|c|c|c|c|c|c|c|c|}
\hline Date & $\begin{array}{c}\text { MCPA, } \\
\text { water, } \\
\text { fltrd } \\
(\mu \mathrm{g} / \mathrm{L})\end{array}$ & $\begin{array}{c}\text { MCPB, } \\
\text { water, } \\
\text { fltrd } \\
(\mu \mathrm{g} / \mathrm{L})\end{array}$ & $\begin{array}{c}\text { Metalaxyl, } \\
\text { water, } \\
\text { fltrd } \\
(\mu \mathrm{g} / \mathrm{L})\end{array}$ & $\begin{array}{c}\text { Methida- } \\
\text { thion, } \\
\text { water, } \\
\text { fltrd } \\
(\mu \mathrm{g} / \mathrm{L})\end{array}$ & $\begin{array}{c}\text { Methio- } \\
\text { carb, } \\
\text { water, } \\
\text { fltrd } \\
(\mu \mathrm{g} / \mathrm{L})\end{array}$ & $\begin{array}{l}\text { Methomyl, } \\
\text { water, } \\
\text { fltrd } \\
(\mu \mathrm{g} / \mathrm{L})\end{array}$ & $\begin{array}{c}\text { Methyl } \\
\text { paraoxon, } \\
\text { water, } \\
\text { fltrd } \\
(\mu \mathrm{g} / \mathrm{L})\end{array}$ & $\begin{array}{c}\text { Methyl } \\
\text { parathion, } \\
\text { water, } \\
\text { fltrd } \\
(\mu \mathrm{g} / \mathrm{L})\end{array}$ & $\begin{array}{c}\text { Metola- } \\
\text { chlor, } \\
\text { water, } \\
\text { fltrd } \\
(\mu \mathrm{g} / \mathrm{L})\end{array}$ \\
\hline June 1-2, 2006 & $<0.07$ & $<0.10$ & $<0.065$ & $<0.009$ & $<0.034$ & $<0.070$ & $<0.02$ & $<0.015$ & $<0.006$ \\
\hline July 1-2, 2006 & $<.07$ & $<.10$ & $<.007$ & $<.009$ & $<.034$ & $<.070$ & $<.02$ & $<.015$ & $<.006$ \\
\hline July 6, 2006 & $<.07$ & $<.10$ & $<.007$ & $<.009$ & $<.034$ & $<.070$ & $<.02$ & $<.015$ & $<.006$ \\
\hline Sept. 9-10, 2006 & $<.07$ & $<.10$ & $<.007$ & $<.009$ & $<.034$ & $<.070$ & $<.02$ & $<.015$ & $<.006$ \\
\hline Sept. 18-19, 2006 & $<.07$ & $<.10$ & $<.007$ & $<.009$ & $<.034$ & $<.070$ & $<.02$ & $<.015$ & $<.006$ \\
\hline Jan. 3-5, 2007 & $<.06$ & $<.20$ & $<.007$ & $<.009$ & $<.040$ & $<.060$ & $<.02$ & $<.008$ & $<.010$ \\
\hline Jan. 24-25, 2007 & $<.06$ & $<.20$ & $<.007$ & $<.009$ & $<.040$ & $<.060$ & $<.02$ & $<.008$ & .228 \\
\hline Mar. 14-15, 2007 & $<.06$ & $<.20$ & $<.011$ & $<.009$ & $<.040$ & $<.060$ & $<.02$ & $<.008$ & .082 \\
\hline May 25, 2007 & $<.06$ & $<.20$ & $<.007$ & $<.009$ & $<.040$ & $<.060$ & $<.02$ & $<.008$ & $<.013$ \\
\hline July 2-3, 2007 & $<.06$ & $<.20$ & $<.007$ & $<.009$ & $<.040$ & $<.060$ & $<.02$ & $<.008$ & E.008 \\
\hline Mar. 10-11, 2008 & $<.06$ & $<.06$ & $<.02$ & $<.004$ & $<.040$ & $<.120$ & $<.01$ & $<.008$ & E.012 \\
\hline July 24, 2008 & $<.06$ & $<.06$ & $<.02$ & $<.004$ & $<.040$ & $<.120$ & $<.01$ & $<.008$ & $<.025$ \\
\hline
\end{tabular}

\begin{tabular}{|c|c|c|c|c|c|c|c|c|c|}
\hline Date & $\begin{array}{l}\text { Metribuzin, } \\
\text { water, } \\
\text { fltrd } \\
(\mu \mathrm{g} / \mathrm{L})\end{array}$ & $\begin{array}{c}\text { Metsulfu- } \\
\text { ron, } \\
\text { water, } \\
\text { fltrd } \\
(\mu \mathrm{g} / \mathrm{L})\end{array}$ & $\begin{array}{c}\text { Myclobu- } \\
\text { tanil, } \\
\text { water, } \\
\text { fltrd } \\
(\mu \mathrm{g} / \mathrm{L})\end{array}$ & $\begin{array}{c}\mathrm{N} \text {-(4-Chloro- } \\
\text { phenyl)-N'- } \\
\text { methylurea } \\
(\mu \mathrm{g} / \mathrm{L})\end{array}$ & $\begin{array}{c}\text { Neburon, } \\
\text { water, } \\
\text { fltrd } \\
(\mu \mathrm{g} / \mathrm{L})\end{array}$ & $\begin{array}{l}\text { Nicosul- } \\
\text { furon, } \\
\text { water, } \\
\text { fltrd } \\
(\mu \mathrm{g} / \mathrm{L})\end{array}$ & $\begin{array}{c}\text { Norflura- } \\
\text { zon, } \\
\text { water, } \\
\text { fltrd } \\
(\mu \mathrm{g} / \mathrm{L})\end{array}$ & $\begin{array}{c}\text { Oryzalin, } \\
\text { water, } \\
\text { fltrd } \\
(\boldsymbol{\mu g} / \mathrm{L})\end{array}$ & $\begin{array}{c}\text { Oxamyl, } \\
\text { water, } \\
\text { fltrd } \\
(\mu \mathrm{g} / \mathrm{L})\end{array}$ \\
\hline June 1-2, 2006 & $<0.028$ & $<0.07$ & $<0.033$ & $<0.04$ & $<0.01$ & $<0.04$ & $<0.02$ & $<0.02$ & $<0.05$ \\
\hline July 1-2, 2006 & $<.028$ & $<.07$ & $<.033$ & $<.04$ & $<.01$ & $<.04$ & $<.02$ & $<.02$ & $<.05$ \\
\hline July 6, 2006 & $<.028$ & $<.07$ & $<.033$ & $<.04$ & $<.01$ & $<.04$ & $<.02$ & $<.02$ & $<.05$ \\
\hline Sept. 9-10, 2006 & $<.028$ & $<.07$ & $<.033$ & $<.04$ & $<.01$ & $<.04$ & $<.02$ & $<.02$ & $<.05$ \\
\hline Sept. 18-19, 2006 & $<.028$ & $<.07$ & $<.033$ & $<.04$ & $<.01$ & $<.04$ & $<.02$ & $<.02$ & $<.05$ \\
\hline Jan. 3-5, 2007 & $<.012$ & $<.14$ & $<.033$ & $<.06$ & $<.02$ & $<.10$ & $<.04$ & $<.04$ & $<.04$ \\
\hline Jan. 24-25, 2007 & $<.012$ & $<.14$ & $<.033$ & $<.06$ & $<.02$ & $<.10$ & $<.04$ & $<.04$ & $<.04$ \\
\hline Mar. 14-15, 2007 & $<.012$ & $<.14$ & $<.033$ & $<.06$ & $<.02$ & $<.10$ & $<.04$ & $<.04$ & $<.04$ \\
\hline May 25, 2007 & $<.012$ & $<.14$ & E.013 & $<.06$ & $<.02$ & $<.10$ & $<.04$ & $<.04$ & $<.04$ \\
\hline July 2-3, 2007 & $<.012$ & $<.14$ & $<.033$ & $<.06$ & $<.02$ & $<.10$ & $<.04$ & $<.04$ & $<.04$ \\
\hline Mar. 10-11, 2008 & E.022 & $<.14$ & $<.010$ & $<.12$ & $<.02$ & $<.10$ & $<.02$ & $<.04$ & $<.12$ \\
\hline July 24, 2008 & $<.012$ & $<.14$ & $<.010$ & $<.12$ & $<.02$ & $<.10$ & $<.02$ & $<.04$ & $<.12$ \\
\hline
\end{tabular}


Appendix 2. Water-quality data for runoff samples collected at West 0so Creek (station 08211517), Nueces County, Texas, water years 2006-08-Continued.

\begin{tabular}{|c|c|c|c|c|c|c|c|c|c|}
\hline Date & $\begin{array}{c}\text { Pendi- } \\
\text { methalin, } \\
\text { water, } \\
\text { fltrd } \\
(\mu \mathrm{gg} / \mathrm{L}\end{array}$ & $\begin{array}{c}\text { Phorate } \\
\text { oxon, } \\
\text { water, } \\
\text { fltrd } \\
(\mu \mathrm{g} / \mathrm{L})\end{array}$ & $\begin{array}{c}\text { Phorate, } \\
\text { water, } \\
\text { fltrd } \\
(\mu \mathrm{g} / \mathrm{L})\end{array}$ & $\begin{array}{c}\text { Phosmet } \\
\text { oxon, } \\
\text { water, } \\
\text { fltrd } \\
(\mu \mathrm{g} / \mathrm{L})\end{array}$ & $\begin{array}{c}\text { Phosmet, } \\
\text { water, } \\
\text { fltrd } \\
(\mu \mathrm{g} / \mathrm{L})\end{array}$ & $\begin{array}{c}\text { Picloram, } \\
\text { water, } \\
\text { fltrd } \\
(\mu \mathrm{g} / \mathrm{L})\end{array}$ & $\begin{array}{c}\text { Prometon, } \\
\text { water, } \\
\text { fltrd } \\
(\mu \mathrm{g} / \mathrm{L})\end{array}$ & $\begin{array}{l}\text { Prometryn, } \\
\text { water, } \\
\text { fltrd } \\
(\mu \mathrm{g} / \mathrm{L})\end{array}$ & $\begin{array}{c}\text { Propyza- } \\
\text { mide, } \\
\text { water, } \\
\text { fltrd } \\
(\mu \mathrm{gg} / \mathrm{L})\end{array}$ \\
\hline June 1-2, 2006 & $<0.022$ & $<0.03$ & $<0.055$ & $<0.05$ & $<0.008$ & $<0.03$ & $<0.01$ & $<0.006$ & $<0.004$ \\
\hline July 1-2, 2006 & $<.022$ & $<.03$ & $<.055$ & -- & -- & $<.03$ & $<.01$ & $<.006$ & $<.004$ \\
\hline July 6, 2006 & 2.66 & $<.03$ & $<.055$ & -- & -- & $<.03$ & $<.01$ & $<.006$ & $<.004$ \\
\hline Sept. 9-10, 2006 & 13.7 & $<.03$ & $<.055$ & $<.05$ & $<.008$ & $<.03$ & $<.01$ & $<.006$ & $<.004$ \\
\hline Sept. 18-19, 2006 & .210 & $<.03$ & $<.055$ & $<.05$ & $<.008$ & $<.03$ & $<.01$ & $<.006$ & $<.004$ \\
\hline Jan. 3-5, 2007 & 6.53 & $<.03$ & $<.020$ & $<.05$ & $<.008$ & $<.12$ & $<.01$ & $<.006$ & $<.004$ \\
\hline Jan. 24-25, 2007 & 2.14 & $<.03$ & $<.020$ & $<.05$ & $<.008$ & $<.12$ & $<.01$ & $<.006$ & $<.004$ \\
\hline Mar. 14-15, 2007 & $<.020$ & $<.03$ & $<.020$ & $<.05$ & $<.008$ & $<.12$ & $<.01$ & $<.006$ & $<.004$ \\
\hline May 25, 2007 & 2.46 & $<.03$ & $<.020$ & $<.05$ & $<.008$ & $<.12$ & $<.01$ & $<.006$ & $<.004$ \\
\hline July 2-3, 2007 & .100 & $<.03$ & $<.020$ & $<.05$ & $<.008$ & $<.12$ & $<.01$ & $<.006$ & $<.004$ \\
\hline Mar. 10-11, 2008 & E.417 & $<.03$ & $<.040$ & $<.05$ & $<.008$ & $<.12$ & $<.01$ & $<.006$ & $<.004$ \\
\hline July 24, 2008 & .252 & $<.03$ & $<.040$ & $<.06$ & $<.008$ & $<.12$ & $<.01$ & $<.006$ & $<.004$ \\
\hline
\end{tabular}

\begin{tabular}{|c|c|c|c|c|c|c|c|c|c|}
\hline Date & $\begin{array}{c}\text { Propham, } \\
\text { water, } \\
\text { fltrd } \\
(\mu \mathrm{g} / \mathrm{L})\end{array}$ & $\begin{array}{c}\text { Propi- } \\
\text { conazole, } \\
\text { water, } \\
\text { fltrd } \\
(\mu \mathrm{g} / \mathrm{L})\end{array}$ & $\begin{array}{c}\text { Propoxur, } \\
\text { water, } \\
\text { fltrd } \\
(\mu \mathrm{g} / \mathrm{L})\end{array}$ & $\begin{array}{c}\text { Siduron, } \\
\text { water, } \\
\text { fltrd } \\
(\mu \mathrm{g} / \mathrm{L})\end{array}$ & $\begin{array}{c}\text { Simazine, } \\
\text { water, } \\
\text { fltrd } \\
(\mu \mathrm{g} / \mathrm{L})\end{array}$ & $\begin{array}{c}\text { Sulfomet- } \\
\text { uron, } \\
\text { water, } \\
\text { fltrd } \\
(\mu \mathrm{g} / \mathrm{L})\end{array}$ & $\begin{array}{l}\text { Tebuthi- } \\
\text { uron, } \\
\text { water, } \\
\text { fltrd } \\
(\mu \mathrm{g} / \mathrm{L})\end{array}$ & $\begin{array}{c}\text { Terbacil, } \\
\text { water, } \\
\text { fltrd } \\
(\mu \mathrm{g} / \mathrm{L})\end{array}$ & $\begin{array}{c}\text { Terbufos } \\
\text { oxon } \\
\text { sulfone, } \\
\text { water, fltrd } \\
(\mu \mathrm{g} / \mathrm{L})\end{array}$ \\
\hline June 1-2, 2006 & $<0.030$ & $<0.01$ & E0.005 & $<0.02$ & 0.009 & $<0.090$ & $<0.02$ & $<0.026$ & $<0.04$ \\
\hline July 1-2, 2006 & $<.030$ & $<.01$ & $<.008$ & $<.02$ & $<.005$ & $<.090$ & $<.02$ & $<.026$ & $<.04$ \\
\hline July 6, 2006 & $<.030$ & $<.01$ & $<.008$ & $<.02$ & $<.005$ & $<.090$ & $<.02$ & $<.026$ & $<.04$ \\
\hline Sept. 9-10, 2006 & $<.030$ & $<.01$ & $<.008$ & $<.02$ & $<.010$ & $<.090$ & $<.02$ & $<.026$ & $<.04$ \\
\hline Sept. 18-19, 2006 & $<.030$ & $<.01$ & $<.008$ & $<.02$ & $<.005$ & $<.090$ & $<.02$ & $<.026$ & $<.04$ \\
\hline Jan. 3-5, 2007 & $<.060$ & $<.06$ & $<.040$ & $<.04$ & $<.006$ & $<.060$ & $<.02$ & $<.040$ & $<.04$ \\
\hline Jan. 24-25, 2007 & $<.060$ & $<.06$ & $<.040$ & $<.04$ & $<.006$ & $<.060$ & $<.02$ & $<.040$ & $<.04$ \\
\hline Mar. 14-15, 2007 & $<.060$ & $<.06$ & $<.040$ & $<.04$ & E.006 & $<.060$ & $<.02$ & $<.040$ & $<.04$ \\
\hline May 25, 2007 & $<.060$ & $<.06$ & $<.040$ & $<.04$ & $<.006$ & $<.060$ & $<.02$ & $<.040$ & $<.04$ \\
\hline July 2-3, 2007 & $<.060$ & $<.06$ & $<.040$ & $<.04$ & .022 & $<.060$ & $<.02$ & $<.040$ & $<.04$ \\
\hline Mar. 10-11, 2008 & $<.040$ & $<.04$ & $<.040$ & $<.02$ & E.017 & $<.060$ & $<.02$ & $<.040$ & $<.04$ \\
\hline July 24, 2008 & $<.040$ & $<.04$ & $<.040$ & $<.02$ & $<.006$ & $<.060$ & $<.02$ & $<.040$ & $<.04$ \\
\hline
\end{tabular}




\section{Hydrologic Conditions and Water Quality of Rainfall and Storm Runoff for Two Agricultural Areas, Oso Creek Watershed}

Appendix 2. Water-quality data for runoff samples collected at West Oso Creek (station 08211517), Nueces County, Texas, water years 2006-08-Continued.

\begin{tabular}{|c|c|c|c|c|c|c|}
\hline Date & $\begin{array}{c}\text { Terbufos, } \\
\text { water, } \\
\text { fltrd } \\
(\mu \mathrm{g} / \mathrm{L})\end{array}$ & $\begin{array}{c}\text { Terbuthyl- } \\
\text { azine, } \\
\text { water, } \\
\text { fltrd } \\
(\mu \mathrm{g} / \mathrm{L})\end{array}$ & $\begin{array}{c}\text { Tribuphos, } \\
\text { water, } \\
\text { fltrd } \\
(\mu \mathrm{g} / \mathrm{L})\end{array}$ & $\begin{array}{c}\text { Triclopyr, } \\
\text { water, } \\
\text { fltrd } \\
\text { ( } \mu \mathrm{g} / \mathrm{L})\end{array}$ & $\begin{array}{c}\text { Trifluralin, } \\
\text { water, } \\
\text { fltrd } \\
(\mu \mathrm{g} / \mathrm{L})\end{array}$ & $\begin{array}{c}\text { Dichlorvos, } \\
\text { water, } \\
\text { fltrd } \\
(\mu \mathrm{g} / \mathrm{L})\end{array}$ \\
\hline June 1-2, 2006 & $<0.02$ & $<0.01$ & $<0.035$ & $<0.03$ & $<0.009$ & $<0.01$ \\
\hline July 1-2, 2006 & $<.02$ & $<.01$ & $<.035$ & $<.03$ & $<.009$ & $<.01$ \\
\hline July 6, 2006 & $<.02$ & $<.01$ & $<.035$ & $<.03$ & .028 & $<.01$ \\
\hline Sept. 9-10, 2006 & $<.02$ & $<.01$ & $<.035$ & $<.03$ & $<.012$ & $<.01$ \\
\hline Sept. 18-19, 2006 & $<.02$ & $<.01$ & $<.035$ & $<.03$ & $<.009$ & $<.01$ \\
\hline Jan. 3-5, 2007 & $<.01$ & $<.01$ & $<.035$ & $<.04$ & $<.009$ & $<.01$ \\
\hline Jan. 24-25, 2007 & $<.01$ & $<.01$ & $<.035$ & $<.04$ & $<.009$ & $<.01$ \\
\hline Mar. 14-15, 2007 & $<.01$ & $<.01$ & $<.035$ & $<.04$ & .020 & $<.01$ \\
\hline May 25, 2007 & $<.01$ & $<.01$ & $<.035$ & $<.04$ & E.050 & $<.01$ \\
\hline July $2-3,2007$ & $<.01$ & $<.01$ & $<.035$ & $<.04$ & $<.009$ & $<.01$ \\
\hline Mar. 10-11, 2008 & $<.02$ & $<.01$ & $<.035$ & $<.04$ & E.019 & $<.01$ \\
\hline July 24, 2008 & $<.02$ & $<.01$ & $<.035$ & $<.04$ & $<.009$ & $<.01$ \\
\hline
\end{tabular}


Appendix 3. Water-quality data for runoff samples collected at Oso Creek tributary (station 08211525), Nueces County, Texas, water years 2006-08.

[unfltrd, unfiltered; $\mu \mathrm{S} / \mathrm{cm}$, microsiemens per centimeter at 25 degrees Celsius; $\mathrm{mg} / \mathrm{L}$, milligrams per liter; $\mathrm{CaCO}_{3}$, calcium carbonate; fltrd, filtered; --, not analyzed; N, nitrogen; E, estimated; <, less than; P, phosphorus; $\mu \mathrm{g} / \mathrm{L}$, micrograms per liter; CIAT, 2-chloro-4-isopropylamino-6-amino-s-triazine; CEAT, 2-Chloro-6-ethylamino-4-amino-s-triazine; OIET, 2-hydroxy-4-isopropylamino-6-ethylamino-s-triazine; DCPA, dimethyl tetrachloroterephthalate; MCPA, 4-chloro-2-methylphenoxy acetic acid; MCPB, 4-(2-methyl-4-chlorophenoxy)butyric acid]

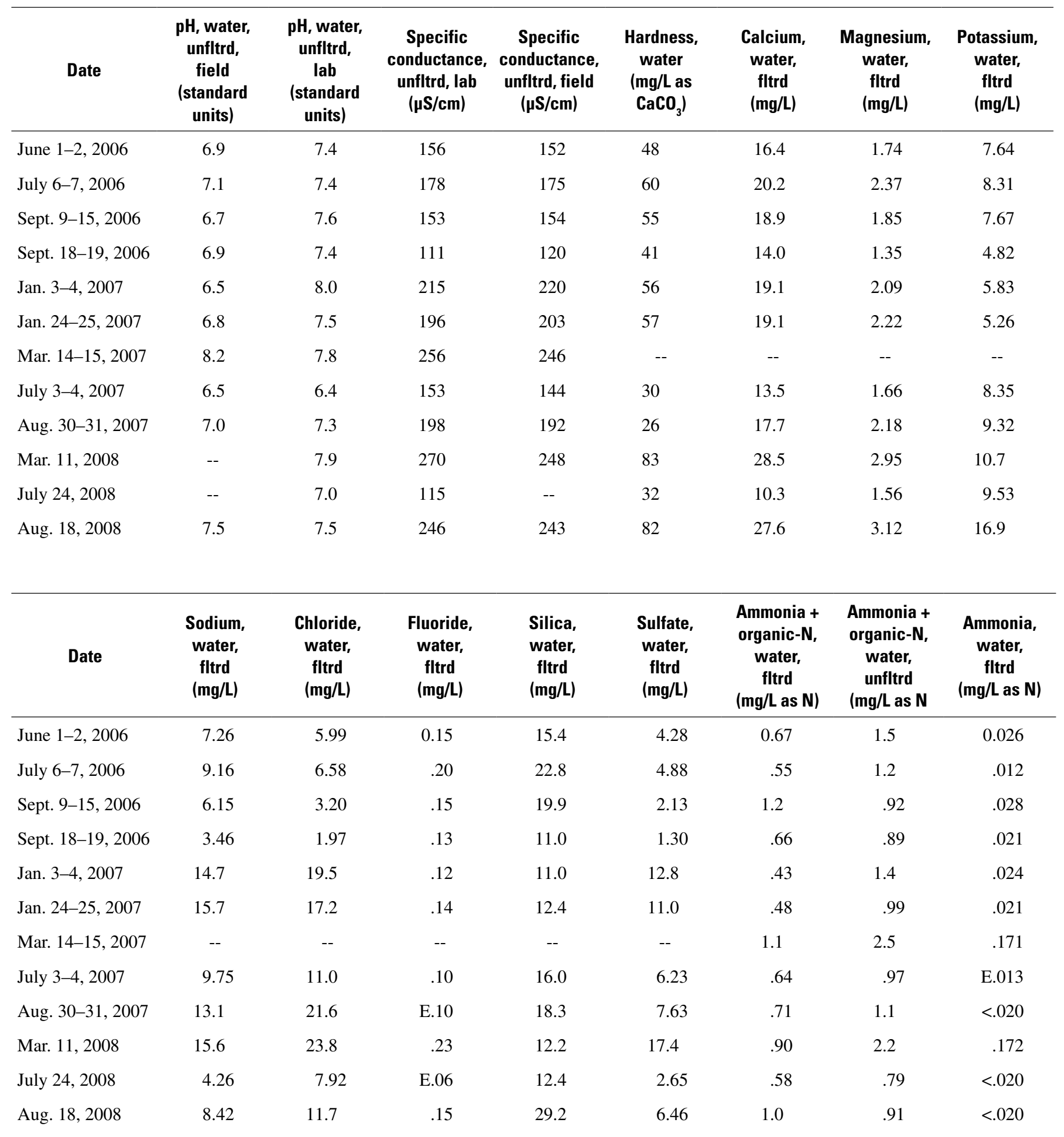


Appendix 3. Water-quality data for runoff samples collected at 0so Creek tributary (station 08211525), Nueces County, Texas, water years 2006-08-Continued.

\begin{tabular}{|c|c|c|c|c|c|c|c|c|c|}
\hline Date & $\begin{array}{c}\text { Nitrate, } \\
\text { water, } \\
\text { fltrd } \\
\text { (mg/L as N) }{ }^{1}\end{array}$ & $\begin{array}{c}\text { Nitrite + } \\
\text { nitrate, } \\
\text { water, } \\
\text { fltrd } \\
\text { (mg/L as N) }\end{array}$ & $\begin{array}{c}\text { Nitrite, } \\
\text { water, } \\
\text { fltrd } \\
\text { (mg/L as } N \text { ) }\end{array}$ & $\begin{array}{c}\text { Organic } \\
\text { nitrogen, } \\
\text { water, } \\
\text { fltrd } \\
\text { (mg/L as N)' }\end{array}$ & \multicolumn{2}{|c|}{$\begin{array}{c}\text { Organic } \\
\text { nitrogen, } \\
\text { water, } \\
\text { unfltrd } \\
\text { (mg/L as N)' }\end{array}$} & $\begin{array}{c}\text { Total } \\
\text { nitrogen, } \\
\text { water, } \\
\text { fltrd } \\
\text { mg/L as N)' }\end{array}$ & $\begin{array}{c}\text { Total } \\
\text { nitrogen, } \\
\text { water, } \\
\text { unfltrd } \\
\left(\mathbf{m g} / \mathrm{L} \text { as N) }{ }^{1}\right.\end{array}$ & $\begin{array}{c}\text { Ortho- } \\
\text { phosphate, } \\
\text { water, } \\
\text { fltrd } \\
\text { (mg/L as } P \text { ) }\end{array}$ \\
\hline June 1-2, 2006 & 0.22 & 0.27 & 0.058 & 0.64 & \multicolumn{2}{|l|}{1.5} & 0.94 & 1.8 & 0.663 \\
\hline July 6-7, 2006 & -- & $<.06$ & .002 & .54 & \multicolumn{2}{|l|}{1.1} & -- & -- & .525 \\
\hline Sept. 9-15, 2006 & .18 & .20 & .016 & 1.2 & \multicolumn{2}{|l|}{.89} & 1.4 & 1.1 & .429 \\
\hline Sept. 18-19, 2006 & .19 & .20 & .005 & .63 & \multicolumn{2}{|l|}{.87} & .85 & 1.1 & .229 \\
\hline Jan. 3-4, 2007 & .49 & .50 & .015 & .40 & \multicolumn{2}{|l|}{1.3} & .93 & 1.9 & .331 \\
\hline Jan. 24-25, 2007 & .80 & .81 & .014 & .46 & \multicolumn{2}{|l|}{.97} & 1.3 & 1.8 & .276 \\
\hline Mar. 14-15, 2007 & .86 & 1.0 & .144 & .92 & \multicolumn{2}{|l|}{2.4} & 2.1 & 3.5 & .366 \\
\hline July 3-4, 2007 & .12 & .13 & .008 & .40 & \multicolumn{2}{|l|}{.96} & .77 & 1.1 & .557 \\
\hline Aug. 30-31, 2007 & .16 & .17 & .009 & .70 & \multicolumn{2}{|l|}{1.1} & .88 & 1.2 & .311 \\
\hline Mar. 11, 2008 & 1.31 & 1.37 & .177 & .72 & \multicolumn{2}{|l|}{2.0} & 2.3 & 3.5 & .550 \\
\hline July 24, 2008 & .05 & .05 & .012 & -- & \multicolumn{2}{|l|}{--} & .63 & .84 & .406 \\
\hline Aug. 18, 2008 & -- & $<.04$ & .011 & -- & \multicolumn{2}{|l|}{--} & -- & -- & .494 \\
\hline Date & $\begin{array}{l}\text { Phosphorus, } \\
\text { water, } \\
\text { fltrd } \\
\text { (mg/L as P) }\end{array}$ & $\begin{array}{c}\text { Phosphorus, } \\
\text { water, } \\
\text { unfltrd } \\
\text { (mg/L as } \mathrm{P} \text { ) }\end{array}$ & $\begin{array}{c}\text { 1-Naphthol, } \\
\text { water, } \\
\text { fltrd } \\
(\mu \mathrm{g} / \mathrm{L})\end{array}$ & $\begin{array}{c}\text { 2,4-D } \\
\text { methylester, } \\
\text { water, } \\
\text { fltrd } \\
(\mu \mathrm{g} / \mathrm{L})\end{array}$ & $\begin{array}{c}\text { 2,4-D, } \\
\text { water, } \\
\text { fltrd } \\
(\mu \mathrm{g} / \mathrm{L})\end{array}$ & $\begin{array}{c}\text { 2,4-DB, } \\
\text { water, } \\
\text { fltrd } \\
(\mu \mathrm{g} / \mathrm{L})\end{array}$ & $\begin{array}{c}\text { 2,6-Diethyl- } \\
\text { aniline, } \\
\text { water, } \\
\text { fltrd } \\
(\mu \mathrm{g} / \mathrm{L})\end{array}$ & $\begin{array}{c}\text { 2-Chloro- } \\
\text { 2',6'-diethyl } \\
\text { acetanilide, } \\
\text { water, fltrd } \\
(\mu \mathrm{g} / \mathrm{L})\end{array}$ & $\begin{array}{c}\text { CIAT, } \\
\text { water, } \\
\text { fltrd } \\
(\mu \mathrm{g} / \mathrm{L})\end{array}$ \\
\hline June 1-2, 2006 & 0.69 & 0.98 & $<0.09$ & $<0.190$ & $<0.04$ & $<0.02$ & $<0.006$ & $<0.006$ & E0.184 \\
\hline July 6-7, 2006 & .55 & .74 & $<.09$ & $<.190$ & .27 & $<.02$ & $<.006$ & $<.006$ & E.089 \\
\hline Sept. 9-15, 2006 & .53 & .61 & $<.09$ & $<.190$ & E.03 & $<.02$ & $<.006$ & $<.006$ & E.029 \\
\hline Sept. 18-19, 2006 & .26 & .45 & $<.09$ & $<.190$ & E.01 & $<.02$ & $<.006$ & $<.006$ & E.021 \\
\hline Jan. 3-4, 2007 & .38 & .61 & $<.09$ & $<.200$ & E.06 & $<.02$ & $<.006$ & $<.006$ & E.011 \\
\hline Jan. 24-25, 2007 & .30 & .43 & $<.09$ & $<.200$ & .09 & $<.02$ & $<.006$ & $<.006$ & E.009 \\
\hline Mar. 14-15, 2007 & .42 & .98 & $<.09$ & .208 & E1.23 & $<.02$ & $<.006$ & $<.006$ & E.119 \\
\hline July 3-4, 2007 & .59 & .66 & $<.09$ & $<.200$ & $<.04$ & $<.02$ & $<.006$ & $<.006$ & E.049 \\
\hline Aug. 30-31, 2007 & .33 & .41 & $<.09$ & $<.200$ & $<.04$ & $<.02$ & $<.006$ & $<.006$ & E.014 \\
\hline Mar. 11, 2008 & .61 & 1.02 & $<.04$ & $<.040$ & .14 & $<.02$ & $<.006$ & $<.010$ & E. 562 \\
\hline July 24, 2008 & .44 & .51 & $<.04$ & $<.040$ & $<.02$ & $<.02$ & $<.006$ & $<.010$ & E.118 \\
\hline Aug. 18, 2008 & .51 & .55 & $<.04$ & $<.040$ & .49 & $<.02$ & $<.006$ & $<.010$ & E.074 \\
\hline
\end{tabular}


Appendix 3. Water-quality data for runoff samples collected at Oso Creek tributary (station 08211525), Nueces County, Texas, water years 2006-08-Continued.

\begin{tabular}{|c|c|c|c|c|c|c|c|c|c|}
\hline Date & $\begin{array}{c}\text { CEAT, } \\
\text { water, } \\
\text { fltrd } \\
(\mu \mathrm{g} / \mathrm{L})\end{array}$ & $\begin{array}{c}\text { 2-Ethyl-6- } \\
\text { methyl- } \\
\text { aniline, } \\
\text { water, fltrd } \\
(\mu \mathrm{g} / \mathrm{L})\end{array}$ & $\begin{array}{c}\text { OIET, } \\
\text { water, } \\
\text { fltrd } \\
(\mu \mathrm{g} / \mathrm{L})\end{array}$ & $\begin{array}{c}\text { 3,4-Di- } \\
\text { chloro- } \\
\text { aniline, } \\
\text { water, } \\
\text { fltrd } \\
(\mu \mathrm{g} / \mathrm{L})\end{array}$ & $\begin{array}{c}\text { 3-Hydroxy } \\
\text { carbofuran, } \\
\text { water, } \\
\text { fltrd } \\
(\mu \mathrm{g} / \mathrm{L})\end{array}$ & $\begin{array}{c}\text { 4-Chloro- } \\
\text { 2-methyl } \\
\text { phenol, } \\
\text { water, fltrd } \\
\text { ( } \mathrm{\mu g} / \mathrm{L})\end{array}$ & $\begin{array}{l}\text { Acetochlor, } \\
\text { water, } \\
\text { fltrd } \\
(\mu \mathrm{g} / \mathrm{L})\end{array}$ & $\begin{array}{c}\text { Acifluorfen, } \\
\text { water, } \\
\text { fltrd } \\
(\mu \mathrm{g} / \mathrm{L})\end{array}$ & $\begin{array}{c}\text { Alachlor, } \\
\text { water, } \\
\text { fltrd } \\
(\mu \mathrm{g} / \mathrm{L})\end{array}$ \\
\hline June 1-2, 2006 & 0.11 & $<0.010$ & 0.420 & $<0.004$ & $<0.008$ & $<0.005$ & $<0.006$ & $<0.028$ & $<0.005$ \\
\hline July 6-7, 2006 & E.07 & $<.010$ & .517 & $<.004$ & $<.008$ & $<.005$ & $<.006$ & $<.028$ & $<.005$ \\
\hline Sept. 9-15, 2006 & $<.08$ & $<.010$ & .272 & $<.004$ & $<.008$ & $<.005$ & $<.006$ & $<.028$ & $<.005$ \\
\hline Sept. 18-19, 2006 & $<.08$ & $<.010$ & .037 & $<.004$ & $<.008$ & $<.005$ & $<.006$ & $<.028$ & $<.005$ \\
\hline Jan. 3-4, 2007 & $<.08$ & $<.010$ & E.043 & $<.004$ & $<.020$ & $<.005$ & $<.006$ & $<.006$ & $<.005$ \\
\hline Jan. 24-25, 2007 & $<.08$ & $<.010$ & E. 023 & $<.004$ & $<.020$ & $<.005$ & $<.006$ & $<.006$ & $<.005$ \\
\hline Mar. 14-15, 2007 & $<.08$ & $<.010$ & .902 & $<.004$ & $<.020$ & $<.005$ & $<.006$ & $<.006$ & $<.005$ \\
\hline July $3-4,2007$ & $<.08$ & $<.010$ & .101 & $<.004$ & $<.020$ & $<.005$ & $<.006$ & $<.006$ & $<.005$ \\
\hline Aug. 30-31, 2007 & $<.08$ & $<.010$ & .021 & $<.004$ & $<.020$ & $<.005$ & $<.006$ & $<.006$ & $<.005$ \\
\hline Mar. 11, 2008 & .08 & $<.010$ & .346 & $<.006$ & $<.040$ & $<.005$ & $<.006$ & $<.040$ & $<.006$ \\
\hline July 24, 2008 & $<.08$ & $<.010$ & .135 & $<.006$ & $<.040$ & $<.005$ & $<.006$ & $<.040$ & $<.006$ \\
\hline Aug. 18, 2008 & $<.08$ & $<.010$ & .266 & E.006 & $<.040$ & $<.005$ & $<.006$ & $<.040$ & $<.006$ \\
\hline
\end{tabular}

\begin{tabular}{|c|c|c|c|c|c|c|c|c|c|}
\hline Date & $\begin{array}{c}\text { Aldicarb } \\
\text { sulfone, } \\
\text { water, } \\
\text { fltrd } \\
(\mu \mathrm{g} / \mathrm{L})\end{array}$ & $\begin{array}{c}\text { Aldicarb } \\
\text { sulfoxide, } \\
\text { water, } \\
\text { fltrd } \\
(\mu \mathrm{g} / \mathrm{L})\end{array}$ & $\begin{array}{c}\text { Aldicarb, } \\
\text { water, } \\
\text { fltrd } \\
(\mu \mathrm{g} / \mathrm{L})\end{array}$ & $\begin{array}{c}\text { Amino- } \\
\text { methyl- } \\
\text { phosphonic } \\
\text { acid, water, } \\
\text { fltrd } \\
\text { ( } \mathrm{gg} / \mathrm{L})\end{array}$ & $\begin{array}{c}\text { Atrazine, } \\
\text { water, } \\
\text { fltrd } \\
(\mu \mathrm{g} / \mathrm{L})\end{array}$ & $\begin{array}{c}\text { Azinphos- } \\
\text { methyl } \\
\text { oxon, } \\
\text { water, } \\
\text { fltrd } \\
\text { ( } \mu \mathrm{g} / \mathrm{L})\end{array}$ & $\begin{array}{l}\text { Azinphos- } \\
\text { methyl, } \\
\text { water, } \\
\text { fltrd } \\
(\mu \mathrm{g} / \mathrm{L})\end{array}$ & $\begin{array}{c}\text { Bendio- } \\
\text { carb, } \\
\text { water, } \\
\text { fltrd } \\
(\mu \mathrm{g} / \mathrm{L})\end{array}$ & $\begin{array}{c}\text { Benfluralin, } \\
\text { water, } \\
\text { fltrd } \\
(\mu \mathrm{g} / \mathrm{L})\end{array}$ \\
\hline June 1-2, 2006 & $<0.02$ & $<0.100$ & $<0.15$ & 0.420 & 1.88 & $<0.04$ & $<0.050$ & $<0.08$ & $<0.010$ \\
\hline July 6-7, 2006 & $<.02$ & $<.100$ & $<.15$ & 1.10 & .313 & $<.04$ & $<.050$ & $<.08$ & $<.010$ \\
\hline Sept. 9-15, 2006 & $<.02$ & $<.100$ & $<.15$ & .350 & .042 & $<.04$ & $<.050$ & $<.08$ & $<.010$ \\
\hline Sept. 18-19, 2006 & $<.02$ & $<.100$ & $<.15$ & .670 & .022 & $<.04$ & $<.050$ & $<.08$ & $<.010$ \\
\hline Jan. 3-4, 2007 & $<.08$ & $<.040$ & $<.04$ & 1.78 & .021 & $<.04$ & $<.080$ & $<.04$ & $<.010$ \\
\hline Jan. 24-25, 2007 & $<.08$ & $<.040$ & $<.04$ & .410 & .021 & $<.04$ & $<.080$ & $<.04$ & $<.010$ \\
\hline Mar. 14-15, 2007 & $<.08$ & $<.040$ & $<.04$ & 1.94 & 9.42 & $<.04$ & $<.080$ & $<.04$ & $<.010$ \\
\hline July 3-4, 2007 & $<.08$ & $<.040$ & $<.04$ & .530 & .194 & $<.04$ & $<.080$ & $<.04$ & $<.010$ \\
\hline Aug. 30-31, 2007 & $<.08$ & $<.040$ & $<.04$ & -- & .012 & $<.04$ & .038 & $<.04$ & $<.010$ \\
\hline Mar. 11, 2008 & $<.08$ & $<.060$ & $<.12$ & -- & 10.5 & $<.04$ & $<.120$ & $<.04$ & $<.010$ \\
\hline July 24, 2008 & $<.08$ & $<.060$ & $<.12$ & -- & .363 & $<.06$ & $<.120$ & $<.04$ & $<.010$ \\
\hline Aug. 18, 2008 & $<.08$ & $<.060$ & $<.12$ & -- & .464 & $<.04$ & $<.120$ & $<.04$ & $<.010$ \\
\hline
\end{tabular}


Appendix 3. Water-quality data for runoff samples collected at Oso Creek tributary (station 08211525), Nueces County, Texas, water years 2006-08-Continued.

\begin{tabular}{|c|c|c|c|c|c|c|c|c|c|}
\hline Date & $\begin{array}{c}\text { Benomyl, } \\
\text { water, } \\
\text { fltrd } \\
(\mu \mathrm{g} / \mathrm{L})\end{array}$ & $\begin{array}{c}\text { Bensulfuron } \\
\text { methyl, } \\
\text { water, fltrd } \\
(\mu \mathrm{g} / \mathrm{L})\end{array}$ & $\begin{array}{c}\text { Bentazon, } \\
\text { water, } \\
\text { fltrd } \\
(\mu \mathrm{g} / \mathrm{L})\end{array}$ & $\begin{array}{c}\text { Bromacil } \\
\text { water, } \\
\text { fltrd } \\
(\mu \mathrm{g} / \mathrm{L})\end{array}$ & \multicolumn{2}{|c|}{$\begin{array}{c}\text { Bromoxynil, } \\
\text { water, } \\
\text { fltrd } \\
(\mu \mathrm{g} / \mathrm{L})\end{array}$} & $\begin{array}{l}\text { Carbaryl, } \\
\text { water, } \\
\text { fltrd } \\
(\mu \mathrm{g} / \mathrm{L})\end{array}$ & $\begin{array}{l}\text { Carbofuran, } \\
\text { water, } \\
\text { fltrd } \\
(\mu \mathrm{g} / \mathrm{L})\end{array}$ & $\begin{array}{c}\text { Chloramben } \\
\text { methyl ester, } \\
\text { water, fltrd } \\
(\mu \mathrm{g} / \mathrm{L})\end{array}$ \\
\hline June 1-2, 2006 & $<0.022$ & $<0.02$ & $<0.02$ & $<0.02$ & $<0.0$ & & $<0.02$ & $<0.016$ & $<0.02$ \\
\hline July 6-7, 2006 & $<.022$ & $<.02$ & $<.02$ & .05 & $<.0$ & & $<.02$ & $<.016$ & $<.02$ \\
\hline Sept. 9-15, 2006 & $<.022$ & $<.02$ & $<.02$ & $<.02$ & $<.0$ & & $<.02$ & $<.016$ & $<.02$ \\
\hline Sept. 18-19, 2006 & $<.022$ & $<.02$ & $<.02$ & $<.02$ & $<.0$ & & $<.02$ & $<.016$ & $<.02$ \\
\hline Jan. 3-4, 2007 & $<.020$ & $<.06$ & $<.02$ & $<.04$ & $<.1$ & & $<.02$ & $<.060$ & $<.10$ \\
\hline Jan. 24-25, 2007 & $<.020$ & $<.06$ & $<.02$ & $<.04$ & $<.1$ & & $<.02$ & $<.060$ & $<.10$ \\
\hline Mar. 14-15, 2007 & $<.020$ & $<.06$ & $<.02$ & $<.04$ & $<.1$ & & $<.02$ & $<.060$ & $<.10$ \\
\hline July 3-4, 2007 & $<.020$ & $<.06$ & $<.02$ & $<.04$ & $<.1$ & & $<.02$ & $<.060$ & $<.10$ \\
\hline Aug. 30-31, 2007 & $<.020$ & $<.06$ & $<.02$ & $<.04$ & $<.1$ & & .010 & $<.060$ & $<.10$ \\
\hline Mar. 11, 2008 & $<.040$ & $<.06$ & $<.04$ & $<.02$ & $<.1$ & & E. 010 & $<.020$ & $<.10$ \\
\hline July 24, 2008 & $<.040$ & $<.06$ & $<.04$ & $<.02$ & $<.1$ & & E.016 & $<.020$ & $<.10$ \\
\hline Aug. 18, 2008 & $<.040$ & $<.06$ & $<.04$ & $<.02$ & $<.1$ & & E. 060 & $<.020$ & $<.10$ \\
\hline Date & $\begin{array}{c}\text { Chlori- } \\
\text { muron, } \\
\text { water, } \\
\text { fltrd } \\
(\mu \mathrm{g} / \mathrm{L})\end{array}$ & $\begin{array}{c}\text { Chloro- } \\
\text { di-amino- } \\
\text { s-triazine, } \\
\text { water, fltrd } \\
(\mu \mathrm{g} / \mathrm{L})\end{array}$ & $\begin{array}{l}\text { Chlorpyrifos- } \\
\text { oxon, } \\
\text { water, } \\
\text { fltrd } \\
(\mu \mathrm{g} / \mathrm{L})\end{array}$ & $\begin{array}{l}\text { Chlorpyrifos, } \\
\text { water, } \\
\text { fltrd } \\
(\mu \mathrm{g} / \mathrm{L})\end{array}$ & $\begin{array}{c}\text { cis- } \\
\text { Permethrin, } \\
\text { water, } \\
\text { fltrd } \\
(\mu \mathrm{g} / \mathrm{L})\end{array}$ & $\begin{array}{c}\text { Clopyralid, } \\
\text { water, } \\
\text { fltrd } \\
(\mu \mathrm{g} / \mathrm{L})\end{array}$ & $\begin{array}{c}\text { Cycloate, } \\
\text { water, } \\
\text { fltrd } \\
(\mu \mathrm{g} / \mathrm{L})\end{array}$ & $\begin{array}{c}\text { Cyfluthrin, } \\
\text { water, } \\
\text { fltrd } \\
(\mu \mathrm{g} / \mathrm{L})\end{array}$ & $\begin{array}{c}\text { Cyper- } \\
\text { methrin, } \\
\text { water, } \\
\text { fltrd } \\
(\mu \mathrm{gg} / \mathrm{L})\end{array}$ \\
\hline June 1-2, 2006 & $<0.032$ & $<0.04$ & $<0.06$ & $<0.005$ & $<0.006$ & $<0.07$ & $<0.01$ & $<0.053$ & $<0.046$ \\
\hline July 6-7, 2006 & $<.032$ & $<.04$ & $<.06$ & $<.005$ & $<.006$ & $<.07$ & $<.01$ & $<.053$ & $<.046$ \\
\hline Sept. 9-15, 2006 & $<.032$ & $<.04$ & $<.06$ & $<.005$ & $<.006$ & $<.07$ & $<.01$ & $<.053$ & $<.046$ \\
\hline Sept. 18-19, 2006 & $<.032$ & $<.04$ & $<.06$ & $<.005$ & $<.006$ & $<.07$ & $<.01$ & $<.053$ & $<.046$ \\
\hline Jan. 3-4, 2007 & $<.080$ & $<.12$ & $<.06$ & $<.005$ & $<.010$ & $<.06$ & $<.06$ & $<.053$ & $<.046$ \\
\hline Jan. 24-25, 2007 & $<.080$ & $<.12$ & $<.06$ & $<.005$ & $<.010$ & $<.06$ & $<.06$ & $<.053$ & $<.046$ \\
\hline Mar. 14-15, 2007 & $<.080$ & $<.12$ & $<.06$ & $<.005$ & $<.010$ & $<.06$ & $<.06$ & $<.053$ & $<.046$ \\
\hline July 3-4, 2007 & $<.080$ & $<.12$ & $<.06$ & $<.005$ & $<.010$ & $<.06$ & $<.06$ & $<.053$ & $<.046$ \\
\hline Aug. 30-31, 2007 & $<.080$ & -- & $<.06$ & $<.005$ & $<.010$ & $<.06$ & $<.06$ & $<.053$ & $<.046$ \\
\hline Mar. 11, 2008 & $<.080$ & -- & $<.06$ & $<.005$ & $<.010$ & $<.06$ & $<.02$ & $<.016$ & $<.014$ \\
\hline July 24, 2008 & $<.080$ & -- & $<.06$ & $<.005$ & $<.010$ & $<.06$ & $<.02$ & $<.016$ & $<.014$ \\
\hline Aug. 18, 2008 & $<.080$ & -- & $<.06$ & $<.005$ & $<.010$ & $<.06$ & $<.02$ & $<.016$ & $<.014$ \\
\hline
\end{tabular}


Appendix 3. Water-quality data for runoff samples collected at Oso Creek tributary (station 08211525), Nueces County, Texas, water years 2006-08-Continued.

\begin{tabular}{|c|c|c|c|c|c|c|c|c|c|}
\hline Date & $\begin{array}{c}\text { Dacthal } \\
\text { mono-acid, } \\
\text { water, } \\
\text { fltrd } \\
(\mu \mathrm{g} / \mathrm{L})\end{array}$ & $\begin{array}{c}\text { DCPA, } \\
\text { water, } \\
\text { fltrd } \\
(\mu \mathrm{g} / \mathrm{L})\end{array}$ & $\begin{array}{c}\text { Desulfinyl- } \\
\text { fipronil, } \\
\text { water, } \\
\text { fltrd } \\
(\mu \mathrm{g} / \mathrm{L})\end{array}$ & $\begin{array}{c}\text { Diazinon, } \\
\text { water, } \\
\text { fltrd } \\
(\mu \mathrm{g} / \mathrm{L})\end{array}$ & $\begin{array}{c}\text { Dicamba, } \\
\text { water, } \\
\text { fltrd } \\
(\mu \mathrm{g} / \mathrm{L})\end{array}$ & $\begin{array}{c}\text { Dichlor- } \\
\text { prop, } \\
\text { water, } \\
\text { fltrd } \\
(\mu \mathrm{g} / \mathrm{L})\end{array}$ & $\begin{array}{c}\text { Dicroto- } \\
\text { phos, } \\
\text { water, } \\
\text { fltrd } \\
(\mu \mathrm{g} / \mathrm{L})\end{array}$ & $\begin{array}{c}\text { Dieldrin, } \\
\text { water, } \\
\text { fltrd } \\
(\mu \mathrm{g} / \mathrm{L})\end{array}$ & $\begin{array}{c}\text { Dimethoate, } \\
\text { water, } \\
\text { fltrd } \\
(\mu \mathrm{g} / \mathrm{L})\end{array}$ \\
\hline June 1-2, 2006 & $<0.03$ & $<0.003$ & $<0.012$ & $<0.005$ & $<0.04$ & $<0.03$ & $<0.08$ & $<0.009$ & $<0.006$ \\
\hline July 6-7, 2006 & $<.03$ & $<.003$ & $<.012$ & $<.005$ & $<.04$ & $<.03$ & $<.08$ & $<.009$ & $<.006$ \\
\hline Sept. 9-15, 2006 & $<.03$ & $<.003$ & $<.012$ & $<.005$ & $<.04$ & $<.03$ & $<.08$ & $<.009$ & $<.006$ \\
\hline Sept. 18-19, 2006 & $<.03$ & Е.004 & $<.012$ & $<.005$ & $<.04$ & $<.03$ & $<.08$ & $<.009$ & $<.006$ \\
\hline Jan. 3-4, 2007 & $<.02$ & $<.003$ & $<.012$ & $<.005$ & $<.08$ & $<.04$ & $<.08$ & $<.009$ & $<.006$ \\
\hline Jan. 24-25, 2007 & $<.02$ & $<.003$ & $<.012$ & $<.005$ & $<.08$ & $<.04$ & $<.08$ & $<.009$ & $<.006$ \\
\hline Mar. 14-15, 2007 & $<.02$ & $<.003$ & $<.012$ & $<.005$ & .97 & $<.04$ & $<.08$ & $<.009$ & $<.006$ \\
\hline July 3-4, 2007 & $<.02$ & $<.003$ & $<.012$ & $<.005$ & $<.08$ & $<.04$ & E.03 & $<.009$ & $<.006$ \\
\hline Aug. 30-31, 2007 & $<.02$ & $<.003$ & $<.012$ & $<.005$ & $<.08$ & $<.04$ & $<.08$ & $<.009$ & $<.006$ \\
\hline Mar. 11, 2008 & $<.02$ & $<.003$ & $<.012$ & $<.005$ & $<.04$ & $<.02$ & $<.08$ & $<.009$ & $<.006$ \\
\hline July 24, 2008 & $<.02$ & $<.003$ & $<.012$ & $<.005$ & $<.04$ & $<.02$ & $<.08$ & $<.009$ & $<.006$ \\
\hline Aug. 18, 2008 & $<.02$ & $<.003$ & $<.012$ & $<.005$ & $<.04$ & $<.02$ & $<.08$ & $<.009$ & $<.006$ \\
\hline
\end{tabular}

\begin{tabular}{|c|c|c|c|c|c|c|c|c|c|}
\hline Date & $\begin{array}{c}\text { Dinoseb, } \\
\text { water, } \\
\text { fltrd } \\
(\mu \mathrm{g} / \mathrm{L})\end{array}$ & $\begin{array}{c}\text { Diphena- } \\
\text { mid, } \\
\text { water, } \\
\text { fltrd } \\
(\mu \mathrm{g} / \mathrm{L})\end{array}$ & $\begin{array}{c}\text { Diuron, } \\
\text { water, } \\
\text { fltrd } \\
(\mu \mathrm{g} / \mathrm{L})\end{array}$ & $\begin{array}{c}\text { Ethion } \\
\text { monoxon, } \\
\text { water, } \\
\text { fltrd } \\
(\mu \mathrm{g} / \mathrm{L})\end{array}$ & $\begin{array}{c}\text { Ethion, } \\
\text { water, } \\
\text { fltrd } \\
(\mu \mathrm{g} / \mathrm{L})\end{array}$ & $\begin{array}{l}\text { Fenami- } \\
\text { phos } \\
\text { sulfone, } \\
\text { water, } \\
\text { fltrd } \\
\text { ( } \mu \mathrm{g} / \mathrm{L})\end{array}$ & $\begin{array}{c}\text { Fenami- } \\
\text { phos } \\
\text { sulfoxide, } \\
\text { water, } \\
\text { fltrd } \\
(\mu \mathrm{g} / \mathrm{L})\end{array}$ & $\begin{array}{l}\text { Fenami- } \\
\text { phos, } \\
\text { water, } \\
\text { fltrd } \\
(\mu \mathrm{g} / \mathrm{L})\end{array}$ & $\begin{array}{c}\text { Fenuron, } \\
\text { water, } \\
\text { fltrd } \\
(\mu \mathrm{g} / \mathrm{L})\end{array}$ \\
\hline June 1-2, 2006 & $<0.04$ & $<0.01$ & E0.02 & $<0.02$ & $<0.016$ & $<0.053$ & $<0.04$ & $<0.03$ & $<0.10$ \\
\hline July 6-7, 2006 & $<.04$ & $<.01$ & .03 & $<.02$ & $<.016$ & $<.053$ & $<.04$ & $<.03$ & $<.10$ \\
\hline Sept. 9-15, 2006 & $<.04$ & $<.01$ & $<.02$ & $<.02$ & $<.016$ & $<.053$ & $<.04$ & $<.03$ & $<.10$ \\
\hline Sept. 18-19, 2006 & $<.04$ & $<.01$ & $<.02$ & $<.02$ & $<.016$ & $<.053$ & $<.04$ & $<.03$ & $<.10$ \\
\hline Jan. 3-4, 2007 & $<.04$ & $<.04$ & $<.04$ & $<.02$ & $<.016$ & $<.053$ & $<.04$ & $<.03$ & $<.04$ \\
\hline Jan. 24-25, 2007 & $<.04$ & $<.04$ & $<.04$ & $<.02$ & $<.016$ & $<.053$ & $<.04$ & $<.03$ & $<.04$ \\
\hline Mar. 14-15, 2007 & $<.04$ & $<.04$ & $<.04$ & $<.02$ & $<.016$ & $<.053$ & $<.04$ & $<.03$ & $<.04$ \\
\hline July 3-4, 2007 & $<.04$ & $<.04$ & $<.04$ & $<.02$ & $<.016$ & $<.053$ & $<.04$ & $<.03$ & $<.04$ \\
\hline Aug. 30-31, 2007 & $<.04$ & $<.04$ & $<.04$ & $<.02$ & $<.016$ & $<.053$ & $<.04$ & $<.03$ & $<.04$ \\
\hline Mar. 11, 2008 & $<.04$ & $<.04$ & .10 & $<.02$ & $<.006$ & $<.053$ & $<.20$ & $<.03$ & $<.04$ \\
\hline July 24, 2008 & $<.04$ & $<.04$ & $<.04$ & $<.02$ & $<.006$ & $<.053$ & $<.20$ & $<.03$ & $<.04$ \\
\hline Aug. 18, 2008 & $<.04$ & $<.04$ & $<.04$ & $<.02$ & $<.006$ & $<.053$ & $<.20$ & $<.03$ & $<.04$ \\
\hline
\end{tabular}


Appendix 3. Water-quality data for runoff samples collected at Oso Creek tributary (station 08211525), Nueces County, Texas, water years 2006-08-Continued.

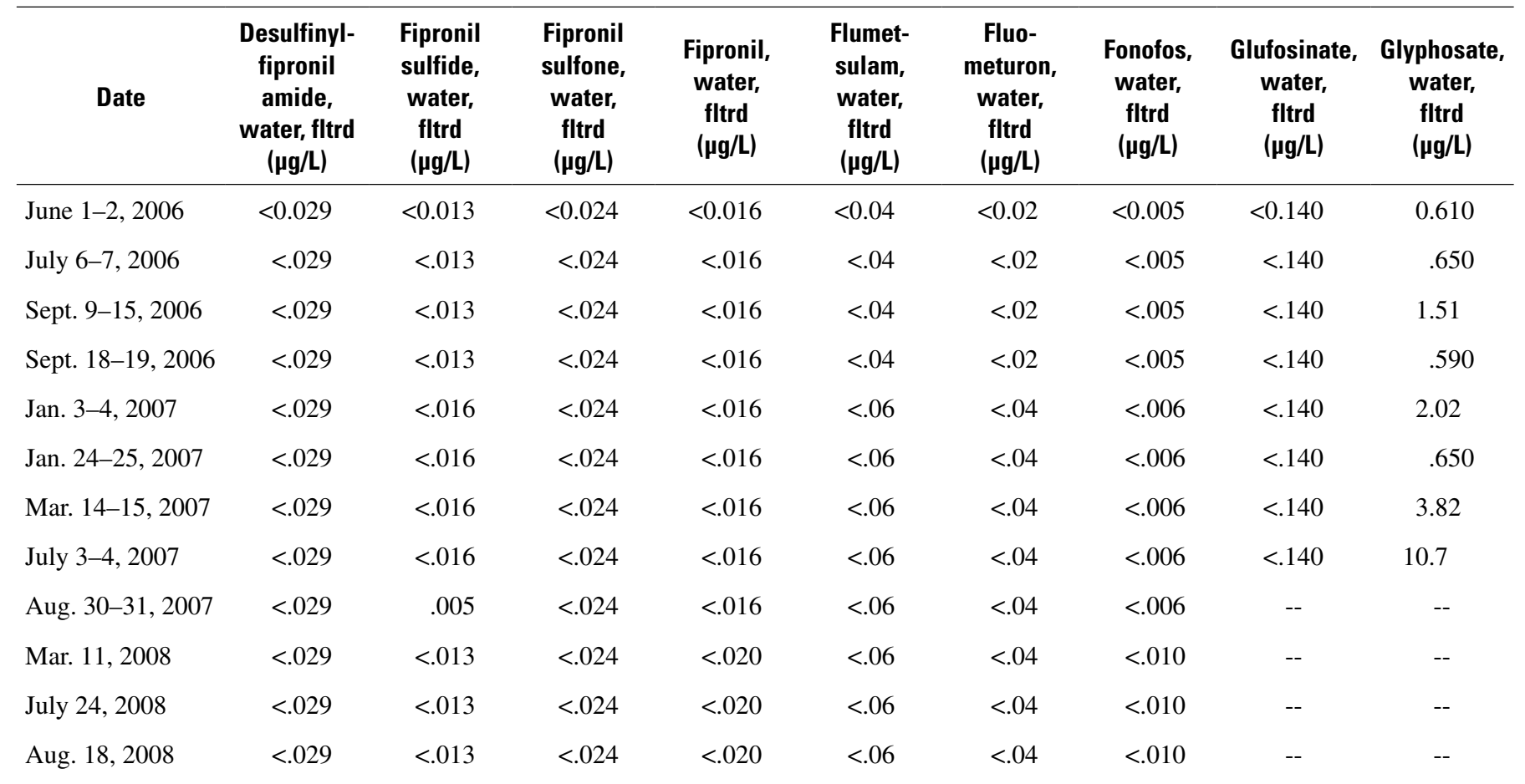

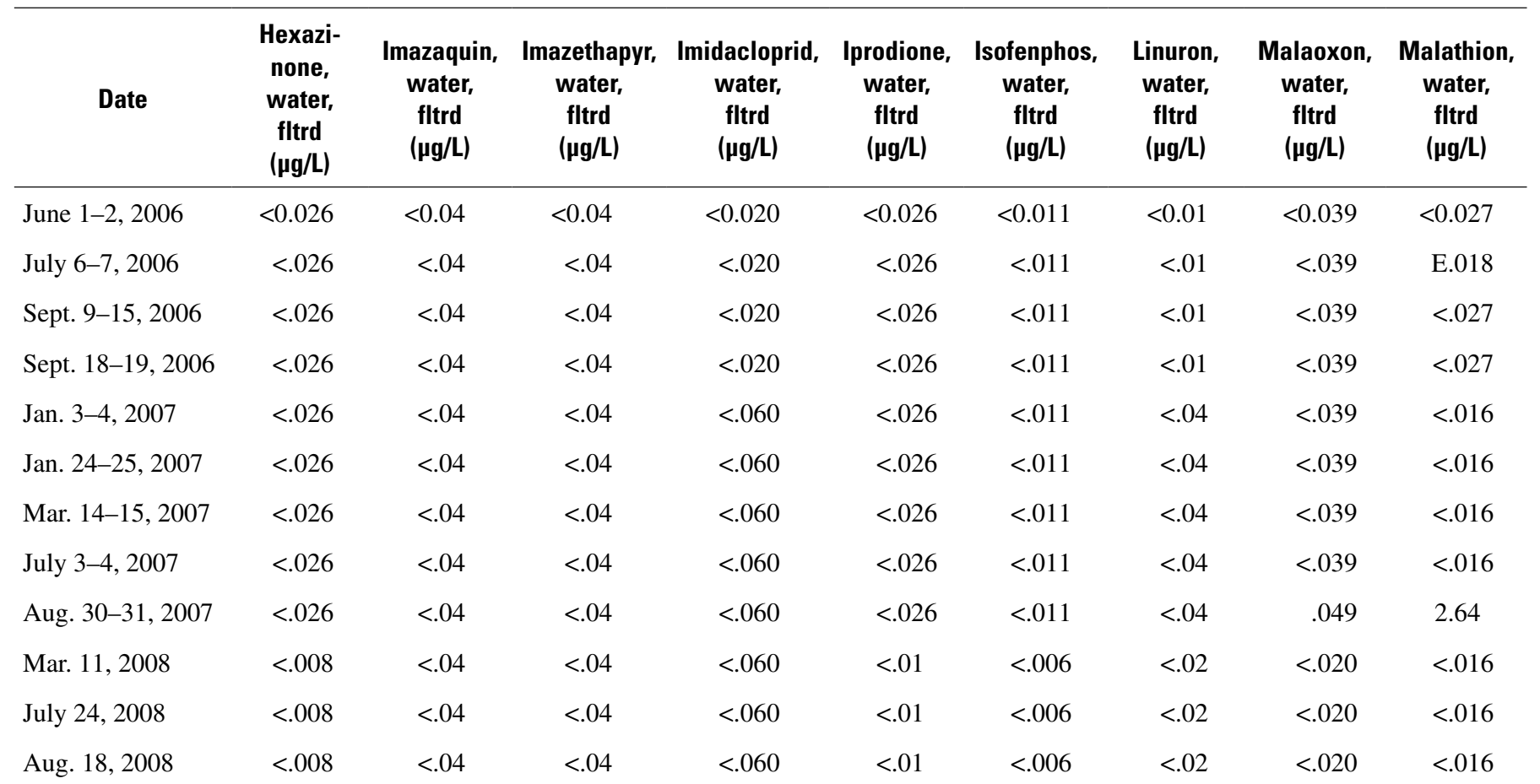


Appendix 3. Water-quality data for runoff samples collected at Oso Creek tributary (station 08211525), Nueces County, Texas, water years 2006-08-Continued.

\begin{tabular}{|c|c|c|c|c|c|c|c|c|c|}
\hline Date & $\begin{array}{c}\text { MCPA, } \\
\text { water, } \\
\text { fltrd } \\
(\mu \mathrm{g} / \mathrm{L})\end{array}$ & $\begin{array}{c}\text { MCPB, } \\
\text { water, } \\
\text { fltrd } \\
(\mu \mathrm{g} / \mathrm{L})\end{array}$ & $\begin{array}{c}\text { Metalaxyl, } \\
\text { water, } \\
\text { fltrd } \\
(\mu \mathrm{g} / \mathrm{L})\end{array}$ & $\begin{array}{c}\text { Methida- } \\
\text { thion, } \\
\text { water, } \\
\text { fltrd } \\
(\mu \mathrm{g} / \mathrm{L})\end{array}$ & $\begin{array}{c}\text { Methio- } \\
\text { carb, } \\
\text { water, } \\
\text { fltrd } \\
(\mu \mathrm{g} / \mathrm{L})\end{array}$ & $\begin{array}{c}\text { Methomyl, } \\
\text { water, } \\
\text { fltrd } \\
(\mu \mathrm{g} / \mathrm{L})\end{array}$ & $\begin{array}{c}\text { Methyl } \\
\text { paraoxon, } \\
\text { water, } \\
\text { fltrd } \\
(\mu \mathrm{gg} / \mathrm{L})\end{array}$ & $\begin{array}{c}\text { Methyl } \\
\text { parathion, } \\
\text { water, } \\
\text { fltrd } \\
(\mu \mathrm{g} / \mathrm{L})\end{array}$ & $\begin{array}{c}\text { Metola- } \\
\text { chlor, } \\
\text { water, } \\
\text { fltrd } \\
(\mu \mathrm{g} / \mathrm{L})\end{array}$ \\
\hline June 1-2, 2006 & $<0.07$ & $<0.10$ & $<0.065$ & $<0.009$ & $<0.034$ & $<0.070$ & $<0.02$ & $<0.015$ & $<0.006$ \\
\hline July 6-7, 2006 & $<.07$ & $<.10$ & $<.007$ & $<.009$ & $<.034$ & $<.070$ & $<.02$ & $<.015$ & E.006 \\
\hline Sept. 9-15, 2006 & $<.07$ & $<.10$ & $<.007$ & $<.009$ & $<.034$ & $<.070$ & $<.02$ & $<.015$ & $<.006$ \\
\hline Sept. 18-19, 2006 & $<.07$ & $<.10$ & $<.007$ & $<.009$ & $<.034$ & $<.070$ & $<.02$ & $<.015$ & $<.006$ \\
\hline Jan. 3-4, 2007 & $<.06$ & $<.20$ & $<.007$ & $<.009$ & $<.040$ & $<.060$ & $<.02$ & $<.008$ & $<.010$ \\
\hline Jan. 24-25, 2007 & $<.06$ & $<.20$ & $<.007$ & $<.009$ & $<.040$ & $<.060$ & $<.02$ & $<.008$ & E.008 \\
\hline Mar. 14-15, 2007 & $<.06$ & $<.20$ & $<.007$ & $<.009$ & $<.040$ & $<.060$ & $<.02$ & $<.008$ & E.007 \\
\hline July 3-4, 2007 & $<.06$ & $<.20$ & $<.007$ & $<.009$ & $<.040$ & $<.060$ & $<.02$ & $<.008$ & $<.010$ \\
\hline Aug. 30-31, 2007 & $<.06$ & $<.20$ & $<.007$ & $<.009$ & $<.040$ & $<.060$ & $<.02$ & $<.008$ & $<.010$ \\
\hline Mar. 11, 2008 & $<.06$ & $<.06$ & E.014 & $<.004$ & $<.040$ & $<.120$ & $<.01$ & $<.008$ & $<.010$ \\
\hline July 24, 2008 & $<.06$ & $<.06$ & $<.007$ & $<.004$ & $<.040$ & $<.120$ & $<.01$ & $<.008$ & $<.011$ \\
\hline Aug. 18, 2008 & $<.06$ & $<.06$ & $<.020$ & $<.004$ & $<.040$ & $<.120$ & $<.01$ & $<.008$ & $<.010$ \\
\hline
\end{tabular}

\begin{tabular}{|c|c|c|c|c|c|c|c|c|c|}
\hline Date & $\begin{array}{l}\text { Metribuzin, } \\
\text { water, } \\
\text { fltrd } \\
(\mu \mathrm{g} / \mathrm{L})\end{array}$ & $\begin{array}{c}\text { Metsulfu- } \\
\text { ron, } \\
\text { water, } \\
\text { fltrd } \\
(\mu \mathrm{g} / \mathrm{L})\end{array}$ & $\begin{array}{c}\text { Myclobu- } \\
\text { tanil, } \\
\text { water, } \\
\text { fltrd } \\
(\mu \mathrm{g} / \mathrm{L})\end{array}$ & $\begin{array}{l}\text { N-(4-Chloro- } \\
\text { phenyl)-N'- } \\
\text { methyl- } \\
\text { urea } \\
(\mu \mathrm{g} / \mathrm{L})\end{array}$ & $\begin{array}{c}\text { Neburon, } \\
\text { water, } \\
\text { fltrd } \\
(\mu \mathrm{g} / \mathrm{L})\end{array}$ & $\begin{array}{c}\text { Nicosul- } \\
\text { furon, } \\
\text { water, } \\
\text { fltrd } \\
(\mu \mathrm{g} / \mathrm{L})\end{array}$ & $\begin{array}{c}\text { Norflura- } \\
\text { zon, } \\
\text { water, } \\
\text { fltrd } \\
(\mu \mathrm{g} / \mathrm{L})\end{array}$ & $\begin{array}{c}\text { Oryzalin, } \\
\text { water, } \\
\text { fltrd } \\
\text { ( } \mu \mathrm{g} / \mathrm{L})\end{array}$ & $\begin{array}{c}\text { Oxamyl, } \\
\text { water, } \\
\text { fltrd } \\
(\mu \mathrm{g} / \mathrm{L})\end{array}$ \\
\hline June 1-2, 2006 & $<0.028$ & $<0.07$ & $<0.033$ & $<0.04$ & $<0.01$ & $<0.04$ & $<0.02$ & $<0.02$ & $<0.05$ \\
\hline July 6-7, 2006 & $<.028$ & $<.07$ & E.012 & $<.04$ & $<.01$ & $<.04$ & $<.02$ & $<.02$ & $<.05$ \\
\hline Sept. 9-15, 2006 & $<.028$ & $<.07$ & E. 010 & $<.04$ & $<.01$ & $<.04$ & $<.02$ & $<.02$ & $<.05$ \\
\hline Sept. 18-19, 2006 & $<.028$ & $<.07$ & $<.033$ & $<.04$ & $<.01$ & $<.04$ & $<.02$ & $<.02$ & $<.05$ \\
\hline Jan. 3-4, 2007 & $<.012$ & $<.14$ & $<.033$ & $<.06$ & $<.02$ & $<.10$ & $<.04$ & $<.04$ & $<.04$ \\
\hline Jan. 24-25, 2007 & $<.012$ & $<.14$ & $<.033$ & $<.06$ & $<.02$ & $<.10$ & $<.04$ & $<.04$ & $<.04$ \\
\hline Mar. 14-15, 2007 & $<.012$ & $<.14$ & $<.033$ & $<.06$ & $<.02$ & $<.10$ & $<.04$ & $<.04$ & $<.04$ \\
\hline July 3-4, 2007 & $<.012$ & $<.14$ & $<.033$ & $<.06$ & $<.02$ & $<.10$ & $<.04$ & $<.04$ & $<.04$ \\
\hline Aug. 30-31, 2007 & $<.012$ & $<.14$ & $<.033$ & $<.06$ & $<.02$ & $<.10$ & $<.04$ & $<.04$ & $<.04$ \\
\hline Mar. 11, 2008 & .021 & $<.14$ & $<.010$ & $<.12$ & $<.02$ & $<.10$ & $<.02$ & $<.04$ & $<.12$ \\
\hline July 24, 2008 & $<.012$ & $<.14$ & $<.010$ & $<.12$ & $<.02$ & $<.10$ & $<.02$ & $<.04$ & $<.12$ \\
\hline Aug. 18, 2008 & $<.012$ & $<.14$ & $<.010$ & $<.12$ & $<.02$ & $<.10$ & $<.02$ & $<.04$ & $<.12$ \\
\hline
\end{tabular}


Appendix 3. Water-quality data for runoff samples collected at Oso Creek tributary (station 08211525), Nueces County, Texas, water years 2006-08-Continued.

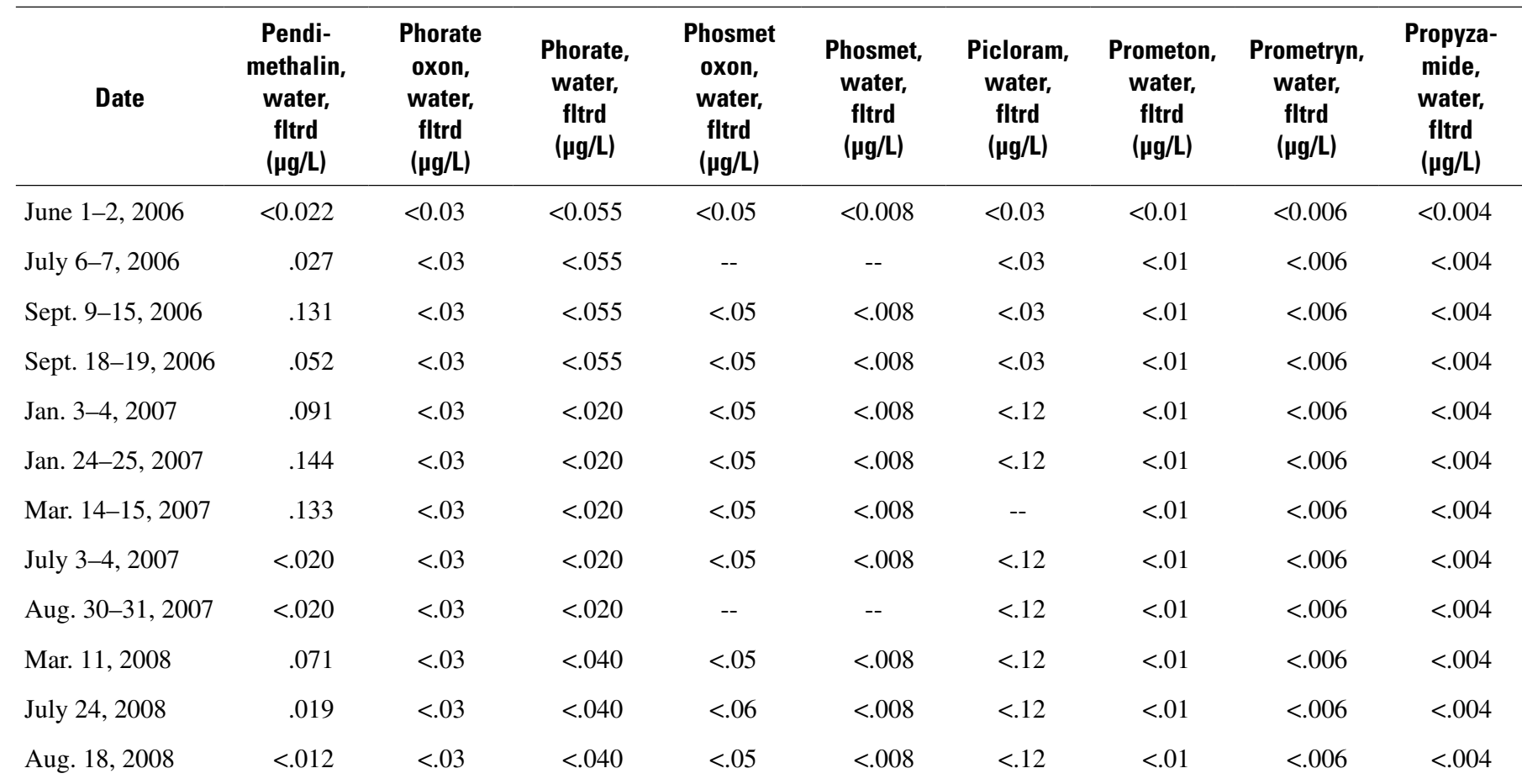

\begin{tabular}{|c|c|c|c|c|c|c|c|c|c|}
\hline Date & $\begin{array}{c}\text { Propham, } \\
\text { water, } \\
\text { fltrd } \\
(\mu \mathrm{g} / \mathrm{L})\end{array}$ & $\begin{array}{c}\text { Propi- } \\
\text { conazole, } \\
\text { water, } \\
\text { fltrd } \\
\text { ( } \mu \mathrm{g} / \mathrm{L})\end{array}$ & $\begin{array}{c}\text { Propoxur, } \\
\text { water, } \\
\text { fltrd } \\
(\mu \mathrm{g} / \mathrm{L})\end{array}$ & $\begin{array}{c}\text { Siduron, } \\
\text { water, } \\
\text { fltrd } \\
\text { ( } \mu \mathrm{g} / \mathrm{L})\end{array}$ & $\begin{array}{c}\text { Simazine, } \\
\text { water, } \\
\text { fltrd } \\
(\mu \mathrm{g} / \mathrm{L})\end{array}$ & $\begin{array}{c}\text { Sulfomet- } \\
\text { ruron, } \\
\text { water, } \\
\text { fltrd } \\
(\mu \mathrm{g} / \mathrm{L})\end{array}$ & $\begin{array}{c}\text { Tebuthi- } \\
\text { uron, } \\
\text { water, } \\
\text { fltrd } \\
\text { ( } \mu \mathrm{g} / \mathrm{L} \text { ) }\end{array}$ & $\begin{array}{c}\text { Terbacil, } \\
\text { water, } \\
\text { fltrd } \\
(\mu \mathrm{g} / \mathrm{L})\end{array}$ & $\begin{array}{c}\text { Terbufos } \\
\text { oxon } \\
\text { sulfone, } \\
\text { water, } \\
\text { fltrd } \\
\text { ( } \mu \mathrm{g} / \mathrm{L} \text { ) }\end{array}$ \\
\hline June 1-2, 2006 & $<0.030$ & $<0.01$ & $<0.008$ & $<0.02$ & 0.019 & $<0.090$ & $<0.02$ & $<0.026$ & $<0.04$ \\
\hline Sept. 9-15, 2006 & $<.030$ & $<.01$ & $<.008$ & $<.02$ & $<.005$ & $<.090$ & $<.02$ & $<.026$ & $<.04$ \\
\hline Sept. 18-19, 2006 & $<.030$ & $<.01$ & $<.008$ & $<.02$ & $<.005$ & $<.090$ & $<.02$ & $<.026$ & $<.04$ \\
\hline Jan. 3-4, 2007 & $<.060$ & $<.06$ & $<.040$ & $<.04$ & E.005 & $<.060$ & $<.02$ & $<.040$ & $<.04$ \\
\hline Jan. 24-25, 2007 & $<.060$ & $<.06$ & $<.040$ & $<.04$ & $<.006$ & $<.060$ & $<.02$ & $<.040$ & $<.04$ \\
\hline Aug. 30-31, 2007 & $<.060$ & $<.06$ & $<.040$ & $<.04$ & $<.006$ & $<.060$ & $<.02$ & $<.040$ & $<.04$ \\
\hline Mar. 11, 2008 & $<.040$ & $<.04$ & $<.040$ & $<.02$ & E.022 & $<.060$ & $<.02$ & $<.040$ & $<.04$ \\
\hline July 24, 2008 & $<.040$ & $<.04$ & $<.040$ & $<.02$ & $<.006$ & $<.060$ & $<.02$ & $<.040$ & $<.04$ \\
\hline Aug. 18, 2008 & $<.040$ & $<.04$ & $<.040$ & $<.02$ & $<.006$ & $<.060$ & $<.02$ & $<.040$ & $<.04$ \\
\hline
\end{tabular}


Appendix 3. Water-quality data for runoff samples collected at Oso Creek tributary (station 08211525), Nueces County, Texas, water years 2006-08-Continued.

\begin{tabular}{|c|c|c|c|c|c|c|}
\hline Date & $\begin{array}{c}\text { Terbufos, } \\
\text { water, } \\
\text { fltrd } \\
(\mu \mathrm{g} / \mathrm{L})\end{array}$ & $\begin{array}{c}\text { Terbuthyl- } \\
\text { azine, } \\
\text { water, } \\
\text { fltrd } \\
(\mu \mathrm{g} / \mathrm{L})\end{array}$ & $\begin{array}{c}\text { Tribuphos, } \\
\text { water, } \\
\text { fltrd } \\
(\mu \mathrm{g} / \mathrm{L})\end{array}$ & $\begin{array}{c}\text { Triclopyr, } \\
\text { water, } \\
\text { fltrd } \\
(\mu \mathrm{g} / \mathrm{L})\end{array}$ & $\begin{array}{l}\text { Trifluralin, } \\
\text { water, } \\
\text { fltrd } \\
(\mu \mathrm{g} / \mathrm{L})\end{array}$ & $\begin{array}{c}\text { Dichlorvos, } \\
\text { water, } \\
\text { fltrd } \\
(\mu \mathrm{g} / \mathrm{L})\end{array}$ \\
\hline June 1-2, 2006 & $<0.02$ & $<0.01$ & $<0.035$ & $<0.03$ & $<0.009$ & $<0.01$ \\
\hline July 6-7, 2006 & $<.02$ & $<.01$ & $<.035$ & $<.03$ & $<.009$ & $<.01$ \\
\hline Sept. 9-15, 2006 & $<.02$ & $<.01$ & $<.035$ & $<.03$ & $<.009$ & $<.01$ \\
\hline Sept. 18-19, 2006 & $<.02$ & $<.01$ & $<.035$ & $<.03$ & .011 & $<.01$ \\
\hline Jan. 3-4, 2007 & $<.01$ & $<.01$ & $<.035$ & $<.04$ & E.007 & $<.01$ \\
\hline Jan. 24-25, 2007 & $<.01$ & $<.01$ & $<.035$ & $<.04$ & $<.009$ & $<.01$ \\
\hline Mar. 14-15, 2007 & .02 & .02 & $<.035$ & $<.04$ & .054 & $<.01$ \\
\hline July 3-4, 2007 & $<.01$ & $<.01$ & $<.035$ & $<.04$ & $<.009$ & $<.01$ \\
\hline Aug. 30-31, 2007 & $<.01$ & $<.01$ & $<.035$ & $<.04$ & $<.009$ & $<.01$ \\
\hline Mar. 11, 2008 & $<.02$ & $<.01$ & $<.035$ & $<.08$ & .026 & $<.01$ \\
\hline July 24, 2008 & $<.02$ & $<.01$ & $<.035$ & $<.08$ & $<.009$ & $<.01$ \\
\hline Aug. 18, 2008 & $<.02$ & $<.01$ & $<.035$ & $<.08$ & $<.009$ & $<.01$ \\
\hline
\end{tabular}

Publishing support provided by Lafayette Publishing Service Center 


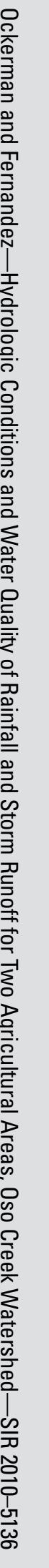

